\title{
WRR
}

WETENSCHAPPELIJKE RAAD VOOR HET REGERINGSBEIEID

\section{Klassieke sharia en vernieuwing}

M.S. Berger 
Klassieke sharia en vernieuw 
De serie Webpublicaties omvat studies die in het kader van de werkzaamheden van de WRR tot stand zijn gekomen. De verantwoordelijkheid voor de inhoud en de ingenomen standpunten berust bij de auteurs. Een overzicht van alle webpublicaties is te vinden op de website van de WRR (www.wrr.nl).

Wetenschappelijke Raad voor het Regeringsbeleid

Lange Vijverberg 4-5

Postbus 20004

2500 EA 's-Gravenhage

Telefoon 070-356 46 oo

Telefax 070-356 4685

E-mail info@wrr.nl

Website http://www.wrr.nl 


\section{WRR}

WETENSCHAPPELIJKE RAAD VOOR HET REGERINGSBELEID

\section{Klassieke sharia en vernieuwing}

dr.mr. M.S. Berger 
Vormgeving: Studio Daniëls BV, Den Haag

ISBN 9053569049

NUR 741

(C) WRR/Amsterdam University Press, Den Haag/Amsterdam 2006

Alle rechten voorbehouden. Niets uit deze uitgave mag worden verveelvoudigd, opgeslagen in een geautomatiseerd gegevensbestand, of openbaar gemaakt, in enige vorm of op enige wijze, hetzij elektronisch, mechanisch, door fotokopieën, opnamen of enige andere manier, zonder voorafgaande schriftelijke toestemming van de uitgever.

Voorzover het maken van kopieën uit deze uitgave is toegestaan op grond van artikel 16B Auteurswet $1912 \mathrm{j}^{\circ}$ het Besluit van 20 juni 1974, Stb. 351, zoals gewijzigd bij het Besluit van 23 augustus 1985, Stb. 471 en artikel 17 Auteurswet 1912, dient men de daarvoor wettelijk verschuldigde vergoedingen te voldoen aan de Stichting Reprorecht (Postbus 3051, $2130 \mathrm{~KB}$ Hoofddorp). Voor het overnemen van gedeelte(n) uit deze uitgave in bloemlezingen, readers en andere compilatiewerken (artikel 16 Auteurswet 1912) dient men zich tot de uitgever te wenden. 


\section{TEN GELEIDE}

De wereldwijde opleving van politieke uitingen van de islam staat de laatste decennia volop in de belangstelling. Een van de opvallendste manifestaties hiervan is het streven naar islamisering van staat en maatschappij door het invoeren van de islamitische wet, de sharia. Velen, niet-moslims maar ook moslims, volgen dit streven met grote achterdocht. Voor hen wordt de sharia dan als vanzelfsprekend het symbool bij uitstek voor alle negatieve handelen 'in naam van de islam': extreem geweld, draconische straffen en herstel van archaïsche verhoudingen tussen mannen en vrouwen. De ervaringen met de toepassing van islamitisch recht in bijvoorbeeld Afghanistan ten tijde van de Taliban geven hier ook alle aanleiding toe. Door dit soort beelden en ontwikkelingen wordt 'de sharia' een uiterst beladen begrip dat veel onrust en angst losmaakt. Het is daarom des te opmerkelijker dat de stroom van publicaties over de politieke manifestaties van de islam veel minder empirische studies bevat over de feitelijke verhouding tussen sharia en nationaal recht in de moslimwereld. Wat de sharia in theorie maar vooral ook in de praktijk behelst, hoe theorie en praktijk zich verhouden tot het nationale, niet-religieuze recht en de universele mensenrechten is nog maar weinig aan systematisch onderzoek onderworpen. Het komt de kwaliteit van beeldvorming en het politieke debat ten goede om dergelijk onderzoek wel beschikbaar te hebben.

De WRR is dan ook uiterst verheugd met de hier voorliggende studie van Maurits Berger. Deze studie maakte onderdeel uit van het onderzoeksproject over sharia en nationaal recht dat het Van Vollenhoven Instituut voor Recht, Bestuur en Ontwikkeling van de Universiteit Leiden op verzoek van de raad heeft verricht. Bergers studie heeft een belangrijke inbreng geleverd aan het WRR-rapport over islamitisch activisme, dat in april 2006 aan de regering is aangeboden.

Voorts wijs ik nog op de volgende studies die eveneens gelijktijdig met dit rapport zijn verschenen:

- J.M. Otto (2006) Sharia en nationaal recht. Rechtssystemen in moslimlanden tussen traditie, politiek en rechtsstaat, WRR-Verkenning nr. 11, Amsterdam: Amsterdam University Press.

- J.M. Otto, A.J. Dekker en L.J. van Soest-Zuurdeeg (red.) (2006) Sharia en nationaal recht in twaalf moslimlanden, WRR-webpublicatie nr. 13, Amsterdam: Amsterdam University Press.

- N. Abu Zayd (2006) Reformation of Islamic Thought. A Critical Historical Analysis, WRR-Verkenning nr. 10, Amsterdam: Amsterdam University Press.

De raad is alle auteurs zeer erkentelijk voor de belangwekkende analyses en inzichten die zij presenteren. 


\section{VOORWOORD}

Dit boek van Maurits Berger komt voort uit het onderzoeksproject 'Sharia en nationaal recht', dat vanaf het najaar van 2003 tot de zomer van 2005 in opdracht van de WRR is uitgevoerd door het Van Vollenhoven Instituut van de Leidse rechtenfaculteit.

Het project 'Sharia en nationaal recht' richt zich in de eerste plaats op de historische veranderingen in de verhouding tussen sharia en nationaal recht in twaalf moslimlanden. Daarnaast belicht het onderzoeksproject hoe deze verhouding in die landen tot uiting komt in het huidige staatsrecht, familierecht, strafrecht en economisch recht. Ten slotte wordt die verhouding bekeken vanuit het perspectief van politieke en maatschappelijke ontwikkeling en van rechtsstaat en mensenrechten.

De twaalf landenstudies, die elk een interessant overzicht bieden van de positie en rol van de sharia in het nationale rechtssysteem van het desbetreffende land, zijn gezamenlijk in boekvorm gepubliceerd. ${ }^{1}$ De onderhavige studie van Berger vormt een belangrijk complement van de landenstudies. Omdat in de landenstudies dikwijls dezelfde termen en aspecten van de sharia aan de orde komen, maar de ruimte ontbreekt daarop dieper in te gaan, was het voor dit project noodzakelijk een afzonderlijke publicatie te maken waarin de sharia zelf centraal staat.

Terwijl in de landenstudies historische, politieke en juridische benaderingen van het onderzochte land domineren, heeft Berger de geschiedenis van de sharia, haar positie op de vier rechtsgebieden en het perspectief van de mensenrechten in de eerste plaats belicht vanuit de studie van het islamitisch recht zelf.

Het werk behandelt eerst de klassieke sharia en vervolgens ontwikkelingen in de moderne tijd. Berger, die zijn kennis niet alleen haalde uit de Arabische en westerse boeken, maar ook woonde in verschillende moslimlanden en enige tijd leerling was van een islamitisch schriftgeleerde, stelt niet alleen het onderscheid tussen vroeger en nu centraal, maar ook tussen theorie en praktijk, en tussen de verschillende betekenisniveaus van het begrip sharia. Door zijn uitgebreide literatuurverwijzingen heeft Berger de studie bovendien ingebed in de hedendaagse internationale studie van de sharia en het recht in de moslimwereld. Ook in dat opzicht biedt zijn werk een belangrijke aanvulling op de andere publicaties van het onderzoeksproject, waarin de rechtsvergelijking en maatschappijwetenschappen een belangrijker plaats innemen. Dankzij de landenstudies én de onderhavige studie van Berger was het mogelijk een brede vergelijkende studie te schrijven waarin de belangrijkste conclusies van het project 'Sharia en nationaal recht' zijn neergelegd. ${ }^{2}$ 
Het is niet eenvoudig om over een complexe materie als 'de sharia' een heldere verhandeling te schrijven. Berger heeft dit gedaan en verdient daarvoor veel waardering. Bij de ordening en analyse van de verschillende visies in en op de sharia heeft hij uiteraard eigen keuzen gemaakt. Dat geldt overigens ook voor de andere onderzoekers van het project. De onderzoeksvragen die aan de verschillende auteurs van de landenrapporten werden voorgelegd waren weliswaar gelijk, maar van een centrale sturing en precieze afstemming van de beantwoording is geen sprake geweest. Om in fiqh-termen te spreken, het motto is geweest ikhtilafuhum rahma, 'hun meningsverschillen zijn een genade'.

$\mathrm{Nu}$ kan men de sharia ten minste op twee manieren bestuderen: vanuit extern en intern perspectief. Externe perspectieven worden meestal gehanteerd door historici, godsdienstwetenschappers, sociologen, juristen en anderen die als buitenstaanders de ontwikkeling, inhoud, kenmerken en betekenis van de sharia onderzoeken en beschrijven. Interne perspectieven zijn die van de schriftgeleerden die zelf de sharia hebben ontwikkeld en werkzaam zijn binnen de kaders van de fiqh-wetenschap (de islamitische rechtsgeleerdheid). Intellectuele hervormers en radicale puriteinen claimen eveneens vanuit intern-godsdienstwettig perspectief te werken. Overigens wordt ook in de westerse rechtssociologie het interne perspectief van de jurist vaak vergeleken met het externe perspectief van de sociaal-wetenschapper die veelal kritisch commentaar geeft op het werk van de eerste.

Grote westerse kenners van het islamitische recht, zowel in de koloniale als postkoloniale tijd hebben zich altijd uitvoerig verdiept in de gedachten en geschriften van de fiqhwetenschappers, in het interne perspectief dus. Dit vergt kennisname van de Arabische bronnen, zowel van de Koran en de belangrijkste verzamelingen van Tradities als van de boeken van vooraanstaande fiqh-leraren, met name van de grondleggers van de voornaamste rechtsscholen of maddhab's. De beoefening van de fiqh-wetenschap staat in de moslimwereld vanouds hoog aangeschreven en heeft velen met scherp intellect aangetrokken, die het vakgebied verder hebben uitgebreid en verrijkt. De analyse van hun werk vormt ook daarom voor westerse wetenschappers een uitdaging.

In Nederland is evenals in Engeland en Frankrijk de bestudering van het islamitisch recht opgekomen in de koloniale tijd. Dat was goed te begrijpen vanuit de praktijkbehoeften van destijds: de koloniale wetgever, bestuurder en rechter hadden tot taak het maatschappelijk leven van een islamitische miljoenenbevolking te reguleren. In Nederlands-Indië moesten zij zich enerzijds houden aan de beginselen van de Nederlandse grondwet en andere wetgeving, en anderzijds hadden zij sterk rekening te houden met de opinies van de traditionele leiders en religieuze schriftgeleerden. Deze laatsten stonden immers in hoog aanzien bij de bevolking. Tussen 1880 en 1940 is er door Nederlandse en Indonesische juristen en islamologen dan ook veel en scherpzinnig geschreven over positie en rol van het islamitisch recht in het overzeese deel van de Nederlandse staat. 
Als het voornaamste Nederlandse standaardwerk uit de koloniale tijd geldt de Handleiding tot de kennis van de Mohammedaansche wet volgens de leer der Sjafïitische school door Th.W. Juynboll, dat in 1903 verscheen. De schrijver droeg zijn werk op aan zijn 'vereerde leermeester' Chr. Snouck Hurgronje, die vanaf de jaren tachtig van de negentiende eeuw een groot aantal gezaghebbende artikelen had geschreven over de islam in Nederlands-Indië. Beiden hanteerden een extern perspectief, maar daarbij toonden zij diepgaande kennis van het interne perspectief der fiqh-geleerden.

In de postkoloniale tijd zette een klein aantal Europese wetenschappers de studie van het islamitisch recht voort. Aanvankelijk leek het erop dat hun werk, hoe degelijk ook, zijn directe belang voor de Nederlandse samenleving had verloren. Het kreeg echter een nieuwe betekenis toen door migratie nieuwe groepen moslims zich in Europa vestigden. In Nederland werd in 1982 de Vereniging tot bestudering van het recht van de Islam en het Midden-Oosten (RIMO) opgericht. J. Brugman, hoogleraar Arabisch, tevens jurist en gespecialiseerd in het islamitische recht, was de eerste voorzitter van deze RIMO. Sinds 1982 houdt de vereniging ieder jaar een symposium, waar doorgaans vier deskundigen aspecten van de sharia belichten. Het accent ligt daarbij op hedendaagse, toegepaste onderwerpen. Door de inspanningen van de RIMO is zo een corpus ontstaan van tientallen belangwekkende artikelen. Na Brugman heeft een jongere generatie de fakkel overgenomen. In Brugmans school van arabist-juristen hebben zich onder anderen gevoegd R. Peters, de huidige RIMO-voorzitter, en M. Berger, de auteur van het onderhavige werk. Ook L. Buskens, begonnen als antropoloog, heeft zich hierbij aangesloten. L. al-Zwaini en N. Sonneveld werken thans aan de voltooiing van hun promotieonderzoek op dit terrein.

Zowel in Europa als in de moslimlanden is de sharia een veelbesproken onderwerp. De grootste aanhangers en critici bedienen zich vooral van one-liners: voor of tegen. Vruchtbaarder is het echter om te kijken wat de sharia inhoudt, welke betekenissen dit begrip heeft, en hoe het in de praktijk vaak op uiteenlopende wijze inhoud krijgt in het praktische doen en denken van mensen in de gehele moslimwereld. Ik hoop daarom dat dit werk van Maurits Berger veel zal worden gelezen en zal bijdragen tot een verbreding en verdieping van de kennis over sharia en nationaal recht in de moslimwereld.

Leiden, oktober 2005

Jan Michiel Otto 


\section{NOTEN}

1 J.M. Otto, A.J. Dekker en L.J. van Soest-Zuurdeeg (2006) (red.) Sharia en nationaal recht in twaalf moslimlanden, WRR Webpublicatie nr. 13, Amsterdam: Amsterdam University Press.

2 J.M. Otto (2006) Sharia en nationaal recht. Rechtssystemen in moslimlanden tussen traditie, politiek en rechtsstaat, WRR-Verkenning nr. 11, Amsterdam: Amsterdam University Press. 
KLASSIEKE SHARIA EN VERNIEUWING

In deze studie is gekozen voor een vereenvoudigde transliteratie van Arabische termen, zonder diakratische tekens (tazir in plaats van ta'zir, khul in plaats van $\left(h_{h l}\right.$ ). Voor de transliteratie is voorts aansluiting gezocht bij de internationale fonetische schrijfwijze (ulama in plaats van oelama, jihad in plaats van djihad). Zie voor de betekenis van de Arabische termen de verklarende woordenlijst achterin het boek. 


\section{INHOUDSOPGAVE}

\section{Ten geleide}

Voorwoord

$1 \quad$ Sharia: enige begripsbepalingen $\quad 13$

$\begin{array}{lll}1.1 & \text { Inleiding } & 13\end{array}$

$\begin{array}{lll}1.2 & \text { De bronnen van de klassieke sharia } & 14\end{array}$

1.3 Drie sharia-begrippen 16

$2 \quad$ Interpretatie en toepassing van de klassieke sharia 21

$2.1 \quad$ Rechtsvinding volgens de fiqh 21

2.2 De actoren van de klassieke sharia: overheid, juristen en theologen 23

$3 \quad$ Staat en bestuur volgens de klassieke sharia 27

$\begin{array}{lll}3.1 & \text { Inleiding } & 27\end{array}$

3.2 Historisch overzicht van staatsvormen in de moslimwereld 27

3.3 Theorievorming over de islamitische staat 29

$3.4 \quad$ Islamitische staat: leiderschap en bestuur 30

$\begin{array}{lll}3.4 .1 & \text { Bij de sunnieten } & 30\end{array}$

$\begin{array}{lll}3.4 .2 & \text { Bij de shiieten } & 31\end{array}$

3.5 Islamitische staat: toepassing van de sharia 33

3.6 Onderdanen van de islamitische staat 33

$4 \quad$ Familie- en erfrecht volgens de klassieke sharia $\quad 37$

$\begin{array}{lll}4.1 & \text { Inleiding } & 37\end{array}$

4.2 Huwelijks-, echtscheidings- en erfrecht 37

$\begin{array}{lll}\text { 4.2.1 Huwelijk } & 38\end{array}$

4.2.2 Echtscheiding 40

$\begin{array}{lll}4.2 .3 & \text { Erfrecht } & 41\end{array}$

$5 \quad$ Strafrecht volgens de klassieke sharia 45

$\begin{array}{lll}5.1 & \text { Inleiding } & 45\end{array}$

5.2 Strafrecht volgens de klassieke sharia 45

5.2.1 Hadd-misdrijven $\quad 46$

5.2.2 Vergelding (jinayat) 49

5.2.3 Beleidsvrijheid (siyasa) 49

6 Economische regelingen volgens de klassieke sharia $\quad 51$

$\begin{array}{lll}6.1 & \text { Inleiding } & 51\end{array}$

$\begin{array}{lll}6.2 W a q f & 51\end{array}$ 
6.3 Riba en gharar 53

6.4 Zakat 54

$\begin{array}{lll}7 & \text { Rechtsvinding en actoren in de moderne tijd } & 57\end{array}$

$\begin{array}{lll}7.1 & \text { Inleiding } & 57\end{array}$

7.2 Nationale wetgevers: modernisering (na ca. 1850) 57

7.3 Nationale wetgevers: islamisering (vanaf ca. 1970) 58

$\begin{array}{lll}7.4 & \text { Rechters } & 59\end{array}$

$\begin{array}{lll}7.5 & \text { Ijtihad-leken } & 60\end{array}$

8 Moderne theorieën over islamitische staatsvormen 65

8.1 Staatsvormen in de negentiende en twintigste eeuw 65

8.2 Moderne theorieën over de islamitische staat 66

$\begin{array}{lll}8.3 & \text { Conclusie } & 69\end{array}$

9 Moderne ontwikkelingen in het familie-, straf- en $\begin{array}{ll}\text { economische recht } & \mathbf{7 1}\end{array}$

9.1 Moderne ontwikkelingen in het familie- en erfrecht 71

$\begin{array}{lll}9.2 & \text { Moderne ontwikkelingen in het strafrecht } & 73\end{array}$

9.3 Moderne ontwikkelingen in het economische recht 74

10 Sharia en mensenrechten $\quad 81$

$\begin{array}{lll}10.1 & \text { Inleiding } & 81\end{array}$

10.2 Sharia en strijdigheid met mensenrechten 82

10.2.1 Gelijkheid en non-discriminatie op grond van geslacht 82

10.2.2 Gelijkheid en non-discriminatie op grond van religie: status van niet-moslims $\quad 83$

10.2.3 Vrijheid van religie en vrijheid van meningsuiting (op het gebied van religie) $\quad 85$

10.2.4 Recht op persoonlijke integriteit 86

$\begin{array}{lll}10.3 & 8 & 87\end{array}$

10.3.1 Internationale 'islamitische' documenten en verdragen 87

10.3.2 Kernpunten van 'islamitische' mensenrechten 88

$\begin{array}{ll}\text { Literatuur } & 93\end{array}$

$\begin{array}{ll}\text { Verklarende woordenlijst } & 99\end{array}$ 


\section{SHARIA: ENIGE BEGRIPSBEPALINGEN}

\subsection{INLEIDING}

\section{Betekenissen van sharia}

De term 'sharia', die vaak wordt vertaald met 'islamitisch recht', is geen eenduidig begrip. Juridisch gezien vormt de sharia geen alomvattend rechtssysteem, omdat het is beperkt tot enkele rechtsgebieden. Bovendien bestaat binnen dat beperkte terrein ruimte voor zeer uiteenlopende interpretaties. Daarnaast is de sharia vaak niet alleen onderwerp van juridische discussies, maar tegenwoordig vooral ook van politiek-religieuze, waarbinnen de meningen over de juiste interpretatie van de sharia vaak uiteenlopen. Waar de één sharia opvat als de klassieke sharia zoals die in de eerste eeuwen na Mohammed werd vastgelegd, houdt de ander er een modernere opvatting op na. Deze verschillen in definiëring en interpretatie zijn niet typisch voor het hedendaagse discours. Zij hebben gedurende de gehele 1400-jarige geschiedenis van de islam een rol gespeeld.

Voor de meeste hedendaagse moslimlanden (dat wil zeggen landen waarin een ruime meerderheid van de bevolking moslim is) geldt dat onverkorte toepassing van de klassieke sharia weinig voorkomt. Slechts enkele landen hebben een volledig op de klassieke sharia gebaseerd rechtssysteem, of pretenderen dat zulks het geval zou zijn; maar zelfs in die landen, zoals Saoedi-Arabië, Iran en Pakistan, blijkt dat de sharia verschillende invullingen krijgt. In het merendeel van de moslimlanden is het nationale familierecht weliswaar min of meer gebaseerd op de klassieke sharia, maar ook dan verschilt het nog van land tot land.

We worden derhalve geconfronteerd met verschillende betekenissen die aan het begrip sharia worden gegeven, waarbij ideaalbeeld, recht, symboliek, theorie en praktijk regelmatig door elkaar lopen. Sommige moslims zullen beweren dat er geen sprake is van 'de' sharia omdat rechtvaardigheid in deze landen ver te zoeken is, anderen menen dat er sprake is van een verkeerde of gecorrumpeerde toepassing van de sharia, en weer anderen beweren dat het juist de verdienste is van de hedendaagse toepassingen van de sharia dat zij de ruimte biedt voor allerlei keuzes en interpretaties van het recht, zodat moslimlanden er ieder op eigen wijze gestalte aan kunnen geven.

\section{Studie van de sharia}

Het is om de hiervoor genoemde redenen dat onderzoekers de sharia op verschillende wijzen benaderen. Binnen de islam is de sharia immers een wetenschapsgebied dat vanouds niet alleen in de handen van rechtsgeleerden (fuqaha) lag, maar ook in die van theologen (ulama). Kennis over de positie van de sharia in de religie van de islam is uitermate belangrijk (Rahman 1979), maar ook bekendheid met de wetenschappe- 
lijke methoden die zowel de moslimse theologen als de rechtsgeleerden binnen de religieuze doctrine toepasten (Hallaq 1984; 1994; 1997; Kamali 1991; Makdisi 1985; Weiss 1978 ) is van belang om te weten hóe de sharia zich historisch heeft ontwikkeld.

Ook de westerse wetenschap heeft zich vanuit verschillende invalshoeken over de sharia gebogen. Het primaat van de juristen (Coulson 1964; Millot 1957; Schacht 1964) bestaat nog steeds (Badr 1978; Hill 1978; Zweigert and Kötz 1996), ofschoon men zou kunnen betogen dat er meer sprake is van historische verhandelingen dan van juridische (Brown 1997; Mayer 1987). Een nieuwe ontwikkeling in het onderzoek naar de sharia is die van de rechtsantropologie, die met name sinds de koloniale tijd opgang doet. Hierin wordt het recht niet alleen beschouwd als het complex van door de centrale wetgever afgekondigde regels, maar als het geheel van normen waar mensen in de praktijk zich naar richten (Botiveau 1990; Dupret 1996; 1999; Masud 2001). Door deze wetenschap wordt tegenwoordig ook aandacht besteed aan bijvoorbeeld gewoonterecht (Ben Nefissa 1999) en informele normatieve praktijken (Bahaa-Eldin 1999). In het navolgende deel zal worden getracht al deze invalshoeken te benutten. Hiertoe dient eerst kort te worden ingegaan op de bronnen en het corpus van de klassieke sharia.

\subsection{DE BRONNEN VAN DE KLASSIEKE SHARIA}

\section{Koran en Sunna}

De sharia (letterlijk: 'weg') is in beginsel geen wetboek of corpus van regels. De sharia is volgens de islamitische orthodoxie het goddelijke plan voor een rechtvaardige maatschappij. Dit plan is door God geopenbaard in Zijn Woord (Koran) en in de handelingen van Zijn Profeet Mohammed (Sunna). ${ }^{1}$ Deze twee bronnen bevatten vanuit juridische optiek echter weinig regels. De regels die er wel in staan zijn beperkt tot enkele rechtsgebieden, met name het familie- en erfrecht. Staats- en bestuursrecht, straf-, fiscaal, burgerlijk, handels- en bovenal procesrecht komen nauwelijks tot niet aan de orde. Ook allerlei juridische instituties, zoals de staat, rechtspraak, bestuur en regelgeving vinden geen concrete uitleg, of worden zelfs niet vermeld.

\section{Fiqh: de rechtswetenschap van de sharia}

Voorzover regels, instituten en begrippen niet zijn uitgelegd in de Koran en de Sunna, werden ze in de eerste eeuwen van de islam ontwikkeld door rechtsgeleerden en theologen (op deze benamingen wordt in het volgende hoofdstuk nader ingegaan). Hun uitgangspunt was dat het goddelijke plan en al zijn voorschriften weliswaar niet manifest waren, maar wel besloten lagen in de heilige teksten van Koran en Sunna. Er ontwikkelde zich een wetenschap waarmee de goddelijke bedoeling voor de maatschappij kon worden achterhaald door de mens. Zowel de rechtsgeleerde wetenschap als het corpus van regels dat daaruit voortkwam wordt aangeduid met de term fiqh.

De fiqh heeft zowel een religieuze als een juridische dimensie, die echter als afzonderlijke elementen werden beschouwd. Zo ruimt de fiqh-literatuur aparte hoofdstukken in 
voor 'handelingen tussen mensen' (mu'amalat) en 'handelingen tussen mens en God' (mu'abadat). Deze juridische en religieuze tweedeling kan voorkomen in één enkele handeling. De verstoting is bijvoorbeeld juridisch geldig, maar religieus verwerpelijk, met als gevolg dat een man weliswaar rechtsgeldig zijn vrouw kan verstoten, maar dat hij in het hiernamaals zal worden afgerekend op deze verwerpelijke handeling.

Kenmerkend voor de fiqh is dat deze niet is ontwikkeld door praktijkjuristen zoals rechters of wetgevers, maar door juridische en theologische schriftgeleerden. De opdracht die deze geleerden vóór zich zagen was niet zozeer het ontwikkelen van een praktisch model voor conflictbeslechting en het inrichten van een samenleving, als wel het achterhalen en uitwerken van Gods plan voor een sociaal-rechtvaardige samenleving. Niettemin heeft de fiqh-literatuur vanwege haar casuïstische karakter altijd gefungeerd als referentiebron voor de rechtspraktijk. Zij wordt hierin wel vergeleken met de Angelsaksische jurisprudence, met dit verschil dat die zelf ook is gebaseerd op de rechtspraktijk, terwijl de fiqh het product is van rechtstheorie. Gedurende de eerste twee eeuwen van de islam (de achtste en negende eeuw $\mathrm{AD}$ ) werd op deze wijze een juridisch corpus ontwikkeld. Dit corpus is zeer omvangrijk en is niet eenduidig: het bevat verschillende interpretaties van dezelfde rechtsregels en soms zelfs onderling tegenstrijdige regels. Dit werd echter - en wordt nog steeds - door moslimse schriftgeleerden niet als een probleem ervaren. Integendeel: het geheel wordt beschouwd als uitwerking van de religieuze bronnen, waarbij het menselijke tekort van de rechtsgeleerden wordt erkend.

\section{Siyasa: de beleidsvrijheid van de overheid}

Overigens was ook de fiqh - in navolging van de Koran - niet alomvattend in de rechtsgebieden die zij bestreek. Op het gebied van procesrecht, strafrecht en staatsen bestuursrecht bevatte de fiqh weinig bepalingen. Dit braakliggende terrein viel derhalve onder de regelgevende bevoegdheid van de overheid. Deze bevoegdheid wordt aangeduid met de term siyasa (wat in het moderne Arabisch het woord is voor 'politiek'). De bevoegdheid die de overheid op grond van siyasa geniet wordt beschouwd als een vrijheid die door de sharia is toegekend. De siyasa dient niet strijdig te zijn met de sharia, maar aangezien de twee bronnen van de sharia zo weinig zeggen over de terreinen die door de siyasa worden bestreken, geniet de siyasa zeer veel speelruimte. Een voorbeeld is het strafrecht: de Koran en de fiqh beperken zich tot een klein aantal delicten, zodat alle overige delicten alsmede vrijwel het gehele strafprocesrecht tot de regelgevende bevoegdheid van de overheid behoren. De herinvoering van 'islamitisch strafrecht', waar tegenwoordig soms sprake van is, betekent dan ook niet een afschaffing van bestaande, aan westers recht ontleende regelgeving van strafrecht en strafprocesrecht, maar het toevoegen van de enkele islamitische delicten in aanvulling op het bestaande strafrecht (zie hoofdstuk 5). Een ander voorbeeld is het familierecht. Weliswaar bevatten Koran en fiqh veel regels op dit gebied, maar de meeste hedendaagse wetgevers van moslimlanden maken gebruik van hun 
siyasa-bevoegdheid om, ieder op eigen wijze, administratief- en procesrechtelijke beperkingen aan te brengen aan de toepassing van rechten als verstoting en polygamie (zie hoofdstuk 4).

\section{Positief recht of onveranderlijke religieuze wet?}

Op grond van het voorgaande is wel betoogd dat de sharia in feite positief recht is, aangezien nagenoeg alle rechtsregels zoals neergelegd in de fiqh (om nog maar te zwijgen over de siyasa) door menselijke arbeid tot stand zijn gekomen (Al-Ashmawi 1998; Chehata 1965). Dit wordt tot op zekere hoogte ook erkend in de rechtstheorie van de fiqh: juridische traktaten worden altijd afgesloten met de woorden 'maar God weet het beter', waarmee wordt aangegeven dat hier slechts sprake is van een menselijke poging Gods Wil te doorgronden (Weiss 1978). Niettemin is de fiqh vrij snel gefossiliseerd, in die zin dat haar het positiefrechtelijke karakter werd ontnomen en dat zij niet als uitwerking van de goddelijke wet werd gezien, maar als die wet zelf. Dit onveranderlijke karakter van zowel klassieke sharia als fiqh wordt in de islamitische orthodoxie altijd benadrukt, en wordt in de meeste westerse studies ook beaamd (Coulson 1964; Zweigert and Kötz 1996). Toch is het recht van de sharia niet zo star als wordt aangenomen, noch in vroegere tijden (Hallaq 1984), noch in moderne tijden. Sedert de negentiende eeuw hebben moderne wetgevers en intellectuelen zichzelf opnieuw regelgevende bevoegdheden toegekend, waarbij gebruik wordt gemaakt van een heel scala van rechtswetenschappelijke methodes die uit de fiqh zijn afgeleid. Op grond van deze ontwikkelingen zou men kunnen betogen dat er sprake is van een hernieuwd rechtspositivisme en zelfs van secularisatie in de rechtsvorming, terwijl men daarbij wel de sharia als formeel referentiekader blijft hanteren (Asad 2001; Bälz 1996; Berger 2005).

\subsection{DRIE SHARIA-BEGRIPPEN}

Op grond van het voorgaande zal hierna aan het begrip sharia drie betekenissen worden toegekend (zie ook Otto 2006, par. 1.5): 1) een door God gegeven maatschappelijk ideaal; 2) de klassieke sharia, het klassieke rechtsstelsel van de fiqh, dat wil zeggen de rechtswetenschap die is ontwikkeld in de eerste eeuwen van de islam en waaruit een corpus van rechtsregels is voortgekomen; 3) hedendaagse varianten op dat klassieke rechtsstelsel, voorkomend binnen nationale rechtsstelsels of binnen sociale en politieke groepen.

\section{Sharia als door God gegeven maatschappelijk ideaal}

Sharia in deze betekenis is het religieuze en metafysische beginsel van een goddelijk plan voor de mensheid. De concrete uitwerking daarvan wordt verondersteld besloten te liggen in de twee bronnen Koran en Sunna. De sharia is derhalve als zodanig eeuwig en onveranderlijk. 
De sharia in deze betekenis verleent legitimiteit aan de hedendaagse roep om 'invoering van de sharia', maar schept verwarring over de bedoeling daarvan: betreft het een algemene oproep tot sociale en maatschappelijke rechtvaardigheid, of doelt het op een concreet rechtssysteem? In het laatste geval rijst de vraag hoe dat rechtssysteem eruit zou moeten zien en, veel belangrijker, hoe dat tot stand moet komen: moet er een islamitische staat worden gevestigd om de sharia in te voeren, zoals met name in de jaren tachtig door de zogeheten ‘islamisten' werd betoogd, of moeten de moslims eerst op individuele basis hun geloof terugvinden, opdat door hun moslim-zijn vanzelf de sharia ten uitvoer wordt gelegd (Ayubi 1991; Roy 1994)? De sharia heeft derhalve een sterk mobiliserende kracht, maar verschaft weinig duidelijkheid over wat het is en hoe het tot stand gebracht moet worden.

\section{Sharia als klassiek rechtsstelsel}

In termen van concrete rechtsregels is de sharia vastgelegd in het corpus van de fiqh. Fiqh is tevens de benaming voor de rechtswetenschap die tot het corpus heeft geleid. Het betreft hier rechtsgeleerdheid gericht op juridisch-religieuze teksten, en in veel mindere mate de werkzaamheid van juristen die zich richten op de rechtspraktijk. De hoofdstukken 2 tot en met 6 zullen over deze 'klassieke sharia' gaan.

\section{De hedendaagse varianten van sharia}

De staatsvormen van moslimlanden in de negentiende en twintigste eeuw hebben verandering in het klassieke rechtsstelsel aangebracht. De klassieke sharia wordt in een aantal grondwetten officieel beschouwd als een bron en als het corpus van regelgeving. Die grondwetten moeten de grondslag vormen van het gehele rechtsstelsel en de rechtspraktijk van een moderne samenleving. Aangezien de klassieke sharia een beperkt aantal rechtsgebieden bestrijkt, heeft deze zienswijze geleid tot nieuwe interpretaties van de fiqh en soms zelfs tot nieuwe vormen van islamitische regelgeving.

Van belang in deze rechtsvinding is de vraag in hoeverre men gebonden is aan alle regels van de klassieke sharia. In de uitleg van het Egyptische Constitutioneel Hooggerechtshof en het Pakistaanse Hoger Sharia Hof, bijvoorbeeld, alsmede in die van veel moderne 'liberale' moslimdenkers (zie voor voorbeelden Kurzman 1998; Rahnema 1994) heeft de sharia in juridische zin slechts betrekking op die regels en instituties die expliciet en duidelijk vermeld staan in de twee primaire rechtsbronnen Koran en Sunna. Dit houdt in dat de onveranderlijkheid van de sharia zich uitsluitend tot deze regels beperkt, zodat er regelgevende vrijheid bestaat ten aanzien van de overige rechtsgebieden. Overigens betekent dit niet dat de landen en denkers die deze uitleg voorstaan tevens alle expliciete regels van de Koran en Sunna ook daadwerkelijk ingevoerd wensen te zien. In geen van de moslimlanden waar de sharia van toepassing is geldt bijvoorbeeld slavernij, hoewel deze wel door de Koran is goedgekeurd. 
In het algemeen kan worden gesteld dat deze interpretatie botst met de visie van conservatieve schriftgeleerden (ulama), die van mening zijn dat de sharia alomvattend is. Echter, wie zich aan de klassieke sharia wil houden, blijft tal van lacunes en interpretatievragen tegenkomen. Om een hedendaags voorbeeld te noemen: de bronnen van de klassieke sharia zeggen in concreto niets over democratie, hetgeen voor sommige moslims reden is om democratie af te wijzen, terwijl andere uit de Koran en Sunna opmaken dat democratie toch zeker onderdeel is van Gods bedoeling (Esposito and Voll 1996). Er bestaat derhalve een tweedeling tussen een beperkte en een alomvattende visie op de juridische relevantie van de sharia, en binnen beide stromingen bestaan weer conservatieve ('letterlijke') en liberale ('rekkelijke') vleugels. De vele daaruit resulterende hedendaagse interpretaties worden alle aangeduid met de term 'sharia'. Deze zullen hierna besproken worden in de hoofdstukken 7 tot en met 11. 


\section{NOTEN}

1 De Sunna is terug te vinden in de duizenden overleveringen (hadith, mv. ahadith, ofwel Tradities) waarin uitspraken en handelingen van de Profeet staan opgetekend. 
KLASSIEKE SHARIA EN VERNIEUWING 


\section{INTERPRETATIE EN TOEPASSING VAN DE KLASSIEKE SHARIA}

\subsection{RECHTSVINDING VOLGENS DE FIQH}

\section{Rechtsbronnen}

In de rechtstheorie van de klassieke sharia wordt uitgegaan van de vier bronnen ('wortels') van de sharia. De twee belangrijkste bronnen zijn de Koran en de Sunna. Dit zijn tevens de enige tekstuele bronnen. Daarnaast worden ijma (consensus) en qiyas (redeneren naar analogie) aangemerkt als de derde en de vierde bron. Het betreft hier geen tekstuele bronnen, maar de erkende methoden van rechtsvinding die mogen worden toegepast op de twee heilige teksten. Wanneer wordt gerefereerd aan 'de vier bronnen van de sharia' heeft dat dus betrekking op de twee heilige tekstbronnen, en de twee methoden van rechtsvinding of -interpretatie (Hallaq 1997).

\section{Hiërarchie van regels}

Het corpus van rechtsregels dat de fiqh heeft opgesteld door middel van deze vier bronnen kent een zekere hiërarchie. Deze heeft te maken met de oorsprong van de regels. Aan de top van de rangorde staan de regels die expliciet in de Koran en de Sunna staan vermeld. In de orthodoxe islam worden deze regels vanwege hun bron beschouwd als onveranderlijk, eeuwig en overal toepasselijk. De circa 6000 verzen in de Koran bevatten maar ongeveer 60 regels die inhoudelijk kunnen worden aangemerkt als rechtsregels. Deze regels betreffen vooral het familie- en erfrecht, en enkele misdrijven (hudud). In aanvulling hierop bevat het omvangrijke corpus van de fiqh talloze rechtsregels die zijn totstandgekomen op grond van de methodes van rechtsvinding (zie volgende paragraaf). De fiqh omvat vijf juridische stromingen ('rechtsscholen': madhhab) die ieder hun eigen interpretaties en uitwerkingen hebben van de vier rechtsbronnen. De shiieten hebben hun eigen rechtsschool (maar wel met sectarische onderverdelingen), de sunnieten hebben er vier: Hanafieten, Shafiieten, Hanbalieten en Malikieten. ${ }^{1}$ Elk van deze scholen heeft eigen interpretaties van het recht, maar ook van de religie van de islam.

Elke moslim behoort tot een van deze rechtsscholen, en zal dus doorgaans ook die interpretatie van de islam en haar regels volgen. Overigens werden deze verschillen tussen de vier scholen in theologisch en juridisch opzicht niet als problematisch ervaren, en werd er ook geen onderlinge scholenstrijd gevoerd, zelfs niet op het gebied van religieuze interpretaties.

De Hanafieten worden beschouwd als de meest liberale rechtsschool, omdat zij veel ruimte laten aan het zelfstandig redeneren van de jurist. De Hanbalieten staan daar tegenover als de meest conservatieve rechtsschool, die veel waarde hecht aan zo 
letterlijk mogelijke interpretatie van de Koran en Sunna. Het essentiële onderscheid tussen de rechtsscholen ligt vooral in de verschillende wijzen waarop zij rechtsregels toepassen. Alleen bij de Malikieten bijvoorbeeld mag de vrouw op bepaalde gronden echtscheiding aanvragen; alleen bij de Hanbalieten mag zij ontbindende voorwaarden opnemen in haar huwelijkscontract; alleen bij de Hanafieten is toestemming van de bruid vereist om een geldig huwelijk te sluiten.

In de fiqh van elk van deze rechtsscholen bestaat ook weer een hiërarchie. Bovenaan staan de regels die bij consensus en analogie zijn vastgesteld (waarbij de regel waar alle rechtsscholen het over eens zijn hoger in rang staat dan die waarover alleen binnen een enkele rechtsschool consensus bestaat). Vervolgens wordt er aan de interpretatie van bepaalde rechtsgeleerden meer gezag toegekend dan aan die van anderen. Met name aan de eerste generaties rechtsgeleerden wordt een grotere autoriteit toegekend dan aan hun latere opvolgers vanwege het feit dat zij de Profeet en Zijn metgezellen persoonlijk hadden gekend. Hun interpretaties worden aangeduid met 'de prevalente mening'.

$\mathrm{Al}$ eerder is vermeld dat de fiqh niet alle rechtsgebieden bestrijkt. De restgebieden behoren tot de regelgevende bevoegdheid (siyasa) van de overheid. Strikt genomen valt de siyasa ook onder de sharia. Immers, zo luidt de redenering, alles wat God niet heeft geregeld heeft Hij toevertrouwd aan Zijn geloofsgemeenschap, en al hetgeen deze beslist maakt deel uit van het grotere goddelijke plan, mits het niet strijdig is met de sharia.

\section{Methodologie van rechtsvinding}

De fiqh is niet alleen de benaming voor het corpus van regels, maar ook voor de rechtswetenschap volgens welke deze regels totstandkwamen. Het beoefenen van de wetenschappelijke methoden om tot bepaalde regels te komen werd beschouwd als een menselijk en vooral intellectueel proces dat ijtihad (letterlijk: 'inspanning', van het woord jihad) wordt genoemd. De theoretische achtergrond hiervan was dat God Zijn sharia heeft neergelegd in de Koran en Sunna, maar aangezien niet alle regels manifest duidelijk waren, deze door het menselijk intellect, met behulp van bepaalde methodologieën, achterhaald dienden te worden. Om dit proces te beschrijven werd vaak de metafoor van de plant gebruikt: de vier rechtsbronnen zijn de wortels, die door de zorg van ijtihad uitgroeien tot een plant, waarvan de takken de regels van de fiqh zijn.

Het praktiseren van ijtihad was overigens niet vrijblijvend. Er waren beperkingen, zowel ten aanzien van de beoefenaars van het intellectuele proces als ten aanzien van de regels waar dit proces betrekking op had. In de tweede eeuw van de islam (de negende eeuw $\mathrm{AD}$ ), toen de theorie van rechtsvinding in haar definitieve vorm was ontwikkeld, was in beginsel iedereen bevoegd tot ijtihad, mits hij was uitgerust met voldoende intellect en afdoende kennis had van de Koran en Sunna. Al spoedig werd dit echter een bevoegdheid die exclusief was voorbehouden aan de islamitische geeste- 
lijkheid, ofwel schriftgeleerden (ulama), met name degenen onder hen die zich hadden bekwaamd in het recht (fuqaha). Ten aanzien van de regels gold dat ijtihad niet kon worden toegepast op die regels die expliciet in de twee primaire rechtsbronnen, Koran en Sunna, stonden vermeld; deze regels waren immers onveranderlijk. Met het voortschrijden van de tijd werd echter ook het resultaat van de ijtihad, de fiqh, een onaantastbaar corpus van regels. Dit is een van de redenen geweest dat in de tweede en derde eeuw van de islam (de negende en tiende eeuw $\mathrm{AD}$ ) een consensus ontstond dat ijtihad op basis van de Koran en de Sunna zijn beslag had gekregen en een einde moest nemen. 'De poorten van de ijtihad zijn gesloten', zo luidde het dogma, en vervolgens begon de periode van 'navolging'(taqlid). Aan het werk dat door de vroege meesters en ijtihad-geleerden is ontwikkeld, is niets meer toe te voegen, zo luidde de redenering, en men kon volstaan met het navolgen van de regels die hun werk had opgeleverd.

\subsection{DE ACTOREN VAN DE KLASSIEKE SHARIA: OVER- HEID, JURISTEN EN THEOLOGEN}

De wijze waarop de klassieke sharia haar uitwerking heeft gekregen, niet alleen op juridisch, maar ook op politiek, religieus en sociaal terrein, is vooral terug te voeren op het onderscheid tussen de islamitische geestelijkheid die het monopolie had op de interpretatie van de sharia, en de wereldlijke macht die de sharia moest implementeren dan wel een bestuur moest voeren dat niet strijdig was met de sharia.

De islamitische geestelijkheid wordt aangeduid met de verzamelnaam ulama, dat letterlijk 'geleerden' betekent en vaak wordt vertaald met 'schriftgeleerden' of 'theologen'. Degenen die zich meer toeleggen op het juridische deel van de fiqh heten fuqaha. Dan zijn er nog de muftis, degenen die fatwas uitvaardigen (dat zijn antwoorden op basis van de sharia, naar aanleiding van individuele vragen). Geleerden met een groot religieus en juridisch gezag kunnen deze functies in één persoon verenigen. Gemakshalve wordt hierna de term ulama gebruikt voor alledrie deze groepen.

In de geschiedenins van de islam zijn de ulama in de uitoefening van hun monopolie op de sharia-interpretatie bij voorkeur onafhankelijk gebleven van de overheid: inmenging van staatswege werd zoveel mogelijk vermeden. Zij vormden daardoor een groep met een controlerende functie: zij zagen erop toe dat de overheid en de gemeenschap der gelovigen zich aan de sharia hielden en dat de overheid de sharia op de juiste wijze handhaafde. Daarmee ontpopten de ulama zich regelmatig als oppositie tegen de overheid. Dat neemt niet weg dat zij ook vaak waren gecoöpteerd door de overheid (het instituut van staatsmufti bijvoorbeeld), dan wel het overheidsbeleid steunden (Crecelius 1997). Maar de ulama hebben door hun bijzondere relatie met de sharia altijd een politieke factor gevormd waarmee terdege rekening moest worden gehouden (Antoun 1989; Berger 1999a; Esposito and Voll 1996; Gaffney 1994; Masud et al. 1996; Skovgaarden-Petersen 1997). 
Aan de zijde van de overheid was men vooral gericht op de praktische toepassing van de sharia. Los van wet- en regelgeving op basis van de bevoegdheid tot siyasa gold dit ook op het gebied van de rechtspraak. Rechters (qadis) onderscheidden zich van de ulama door het feit dat zij in overheidsdienst waren, en vaak de deskundigheid ontbeerden om de sharia te doorgronden. Voor de toepassing daarvan wonnen zij dan juridisch advies in de vorm van een fatwa in bij de ulama. De rechters behoorden derhalve tot de uitvoerende macht en genoten in het algemeen veel minder aanzien dan de ulama (Coulson 1969; Weiss 1978).

Anders dan de rechters werden de ulama niet benoemd: zij ontleenden hun status slechts aan hun kennis en aan het gezag dat de bevolking hun op grond daarvan toekende. Iedereen kon tot de ulama behoren, zelfs vrouwen en slaven (wat bij het rechtersambt bijvoorbeeld niet was toegestaan), omdat kennis van Gods Woord toegankelijk werd verondersteld voor alle mensen die begiftigd waren met voldoende verstand. Weliswaar waren er families die bekend stonden om hun ulama, maar het was geen positie die door erfopvolging kon worden ingenomen. De ulama werden primair beoordeeld op hun kennis van de sharia, en hun status werd vooral afgemeten naar het aantal mensen dat hem of haar om sharia-advies vroeg (Berger 1999a). 


\section{NOTEN}

1 De Malikieten zijn vooral geconcentreerd in Noord- en West-Afrika, de Hanbalieten in het Arabisch Schiereiland, de Hanafieten in het Midden-Oosten en Centraal-Azië, en de Shafiieten in Zuidoost-Azië en Indonesië (Schacht 1964: 63-65). 
KLASSIEKE SHARIA EN VERNIEUWING 


\section{STAAT EN BESTUUR VOLGENS DE KLASSIEKE SHARIA}

\subsection{INLEIDING}

Staats- en bestuursrecht zijn rechtsgebieden die in de Koran, de Sunna en de fiqh weinig aandacht krijgen. Deze rechtsgebieden behoren bij uitstek tot de siyasa, de regelgevende bevoegdheid van de overheid. Maar zelfs de praktijk van eeuwenlange staatkundige regelgeving door moslimoverheden heeft nauwelijks aanleiding gegeven tot het formuleren van een staatkundig model. ${ }^{1}$ Een blauwdruk van 'de' islamitische staat is dus niet voorhanden. Zowel de term 'islamitische staat' (in het Arabisch: aldawla al-islamiya) als de discussie daarover is niet veel ouder dan vijftig jaar. Deze discussie is complex: zij wordt aangestuurd door omstandigheden van nu, maar put haar inspiratie uit voorbije tijden, waarbij het doel is gericht op de toekomst. Het is ook grotendeels een theoretische discussie, die slechts enkele keren in praktijk is gebracht, zoals in Pakistan en Iran. Onder moslims lopen de zienswijzen over de islamitische staat daarom vaak sterk uiteen. Niettemin bestaat er redelijke unanimiteit onder voorstanders van een islamitische staat: deze heeft ten doel de sharia te implementeren en te behoeden. Verschil van mening bestaat met name over de wijze van totstandkoming van deze staat, en de definitie van 'de sharia'.

Hierna zal een overzicht worden gegeven van de historische en theoretische ontwikkelingen van de islamitische staat en de islamitische staatkunde.

\subsection{HISTORISCH OVERZICHT VAN STAATSVORMEN IN DE MOSLIMWERELD}

\section{Zevende tot tiende eeuw AD: stichting van een wereldrijk}

Door het overlijden van de Profeet Mohammed in het jaar 632 werd de jonge moslimgemeenschap geconfronteerd met het probleem van de opvolging. De Profeet had geen zonen en de meningen waren verdeeld tussen enerzijds degenen die een 'opvolger' (kalief) wilden kiezen uit de moslimgemeenschap en anderzijds degenen die meenden dat alleen een bloedverwant van de Profeet geschikt was als 'leider' (imam) van de moslims. De eerste groep kreeg later bekendheid als sunnieten ('degenen van de traditie') en de tweede groep als de shiieten ('de aanhangers', namelijk de aanhangers van Ali, de neef van de Profeet die tevens was getrouwd met de dochter van de Profeet). De sunnieten waren vanaf het begin numeriek in de meerderheid en de shiieten werden al snel militair verslagen en gemarginaliseerd. Op de shiieten en het imamaat komen wij later terug (par. 3.4). 
Onder de sunnieten werden alleen de eerste vier kaliefs gekozen; daarna heeft het kalifaat zich tot zijn opheffing in 1924 voortgezet via erfopvolging. Na de periode van de eerste vier kaliefen, die wordt aangeduid als 'de periode der Rechtgeleide Kaliefen' (632-661 AD), volgde de dynastie der Ummayaden (661-750 AD). Gedurende deze periode veroverden de Arabische moslimlegers in zeer korte tijd een wereldrijk, dat reikte van Noord-Afrika tot Afghanistan. Dit staatkundige gebied dat onder leiderschap stond van de kalief, werd aangeduid met de geografisch-religieuze term 'Huis van de Islam' (Dar al-Islam).

De ervaring van de Arabische moslimheersers in het besturen van een stam of een clan was van weinig waarde in hun nieuwe wereldrijk. Zij vielen daarom in eerste instantie terug op de bestuursstructuren van het Byzantijnse rijk, en van het Perzische rijk dat zij hadden veroverd. Onder de dynastie der Abassieden (750-950 AD) ${ }^{2}$ kwam de 'Gouden Eeuw' van de islam tot stand: Bagdad werd de hoofdstad van het rijk, waar niet alleen de kunsten en wetenschappen floreerden, maar ook een omvangrijke bureaucratische en centralistische bestuursstructuur werd gevestigd.

De eerste kaliefen waren 'all round' leiders: zij waren zowel bestuurder, generaal, arbiter als kenner en interpretator van de sharia. Met de uitbreiding van het islamitische rijk en de dienovereenkomstige omvang van verantwoordelijkheden werden deze functies in toenemende mate gedelegeerd aan, dan wel overgenomen door de posities van minister (wazir), generaal (emir), rechter (qadi) en de religieuze schriftgeleerden (ulama) (Tamandonfar 1989: 115; Tyan 1999: 628-632). Niettemin werden de kaliefen gezien als hoeders van de islam, en waren veel Abassiedische kaliefen, bijvoorbeeld, actief in het vervolgen van ketters en het steunen van bepaalde islam-interpretaties (Sourdel 1990: 940).

\section{Tiende tot negentiende eeuw AD: het islamitische rijk valt uiteen}

Vanaf de tiende eeuw begon de bestuurlijke eenheid van het islamitische rijk te verbrokkelen. Er ontstonden (semi-)onafhankelijke gebieden die werden vernoemd naar de lokale bevelhebber (emir - emiraat) of vorst (sultan - sultanaat). Ook in gebieden buiten het hartland van het islamitische rijk, zoals West-Afrika, CentraalAzië, India en Zuidoost-Azië, ontstonden vorstendommen met lokale staatsvormen (khanaten in Centraal-Azië, tribale staten in West-Afrika).

Met een enkele uitzondering ${ }^{3}$ werd echter nimmer aanspraak gemaakt op de titel 'kalief'. Weliswaar had het kalifaat feitelijk opgehouden te bestaan, maar aan de religieuze autoriteit van de kalief werd nog wel lippendienst bewezen (Sourdel 1990: 945). Het uiteenvallen van het islamitische rijk in de tiende eeuw resulteerde in een langdurige reeks van machtsconflicten en (burger)oorlogen, waarbij ook invallen vanuit het buitenland (Kruisvaarders, Mongolen, Seldjukken) zich deden gelden. Pas zes eeuwen later, in de zestiende eeuw, ontstonden nieuwe, grote machtsblokken: de Ottomanen 
in het Westen, Safaviden in Iran en Moghuls in India. Daarbij had de Ottomaanse sultan officieel het kalifaat op zich genomen, hetgeen stilzwijgend werd aanvaard door de moslimgemeenschap.

Na de Eerste Wereldoorlog werd het Ottomaanse rijk definitief ontmanteld. Atatürk schafte in 1924 formeel het kalifaat af. Het is opvallend dat dit nauwelijks enige reacties teweegbracht in de moslimwereld, en dat de roep om herstel van het kalifaat sindsdien nagenoeg non-existent is geweest. Nog opvallender is dat het kalifaat nauwelijks figureert in moderne theorieën over de islamitische staat. Hier wordt later nader op ingegaan (zie hoofdstuk 8).

\subsection{THEORIEVORMING OVER DE ISLAMITISCHE STAAT}

In de islamitische bronnen - Koran, Sunna, fiqh - komt het beginsel van de staat of staatsinrichting niet voor. Het centrale concept in deze bronnen is de wereldwijde geloofsgemeenschap der moslims (umma). Het doel van deze gemeenschap is het naleven van Gods sharia. Dat is het bindende element van de leden van deze gemeenschap; niet sociaal-politiek, maar ideologisch-religieus (Siegman 1964: 14). Het enige dat hen bindt is hun geloof, met uitsluiting van alle andere verschillen zoals afkomst, ras, nationaliteit of huidskleur. De gemeenschap der moslims vormt daarom bijvoorbeeld ook geen geopolitieke eenheid: de enige politieke grens die de klassieke sharia kent is die welke het leefgebied der moslims (Dar al-Islam) scheidt van het leefgebied der ongelovigen (Dar al-Harb) ${ }^{4}$.

De inrichting en regulering van de umma waren in theoretisch opzicht van ondergeschikt belang, aangezien solidariteit onder de leden van de gemeenschap wordt vóórondersteld (Lambton 1981: xv). Dit heeft ook zijn weerslag op de wijze waarop de relatie tussen staat en individu wordt bezien: deze wordt niet beschouwd als een tegenstelling, aangezien beide deel uitmaken van dezelfde umma. Vanuit dit standpunt bezien bestaan er geen conflicten tussen staat en individu, en heeft zich derhalve geen politiek of filosofisch gedachtegoed over de aard of de oplossing van dergelijke conflicten gevormd (Lambton 1981: xv; Coulson 1957: 59). Het reguleren van de (rechts-)verhouding tussen staat en individu is bovendien niet relevant, omdat zowel de staat als het individu is onderworpen aan de sharia. De individuele gelovige heeft dus geen rechten jegens de staat als zodanig, maar heeft jegens de leider (kalief of imam) wel het recht te verwachten dat deze handelt in overeenstemming met de sharia (Siegman 1964: 23).

Het voorgaande verklaart waarom Koran, Sunna en fiqh nauwelijks regels omtrent staatsen bestuursrecht bevatten. Ook staatsinstituties als de rechter/arbiter (hakim) en voorganger/leider (imam) worden slechts summier vermeld in de Koran. Staats- en bestuursrecht behoren derhalve tot de regelgevende bevoegdheid van de overheid zelf (siyasa). 
Maar ook de staatsrechtelijke praktijk van het islamitische rijk zoals die in de eerste eeuwen van de islam haar beslag kreeg, heeft nauwelijks aanleiding gegeven tot theorievorming, noch tot het ontwikkelen van staatsmodellen. De enige uitzondering betrof de positie van de leider (kalief of imam): zijn functies en persoonlijke kenmerken, de wijze van benoeming en de mogelijkheden voor afzetting.

\subsection{ISLAMITISCHE STAAT: LEIDERSCHAP EN BESTUUR}

\subsubsection{BIJ DE SUNNIETEN}

In de tijd van de Profeet en de vier Rechtgeleide Kaliefen speelden het bestuur en het leiderschap van de moslimgemeenschap zich voornamelijk af in de stadjes Mekka en Medina. Moderne moslimdenkers voeren als voorwaarden voor de benoeming van het leiderschap van de islamitische staat de volgende drie concepten aan, die volgens hen een belangrijke rol speelden bij de verkiezing van de eerste vier kaliefen (Sourdel 1990; Tamadonfar 1989: 84 e.v.; Tyan 1999: 126 e.v.).

\section{Beraadslaging (shura)}

De Koran zegt over beraadslaging het volgende: '(de gelovigen zijn zij) wier beleid onderling beraad is' (42: 38). Een praktisch probleem is dat beraadslaging wel als concept wordt genoemd, maar dat de procedure die daaraan ten grondslag ligt niet door de Koran of de Sunna wordt aangegeven, zodat de vraag rijst wie bevoegd is tot beraadslaging: alleen de ulama, alleen de notabelen, of misschien zelfs het hele volk? In het geval van de Rechtgeleide Kaliefen werd de eerste kalief door de gemeenschap der moslims collectief gekozen en de daaropvolgende kaliefen door een raad (die eveneens de naam shura droeg).

\section{Consensus (ijma)}

De leden van de shura dienden in consensus te beslissen over de te verkiezen kalief. Deze regel had zijn basis in de Sunna, waarin de Profeet zegt: "Mijn geloofsgemeenschap (umma) kan geen fout begaan." Maar net als bij de beraadslaging wordt geen melding gemaakt van een procedure voor de wijze waarop de consensus tot stand moet komen.

\section{Bekrachtiging door het volk (baya)}

Na verkiezing van de kalief diende zijn autoriteit erkend te worden door de overige leden van de moslimgemeenschap. De baya was een soort eed van trouw, die al in preislamitische tijden door familiehoofden aan de leider van de clan werd afgelegd, door clanhoofden aan de leider van de stam, enzovoort (Tyan 1999: 136 e.v.). 
De Rechtgeleide Kaliefen waren leiders in politieke én religieuze zin. Zij beslisten in militaire, civiele en bestuurlijke zaken en waren bij uitstek bevoegd om uitspraken te doen over de interpretatie van de sharia. In de daaropvolgende kalifaten veranderden deze bevoegdheden, hetgeen zowel de positie van de kalief als de eenheid van religie en staat aantastte. De kaliefen eisten onvoorwaardelijke gehoorzaamheid, waarbij zij zich beriepen op hun door God gegeven leiderschap (Sourdel 1990). De politieke en religieuze rechtvaardiging die hiervoor werd aangevoerd was echter niet zo eenduidig. Enerzijds waren er ulama die gehoorzaamheid aan de leider van de umma als een religieuze plicht zagen, waarbij vooral de vrees voor chaos en rebellie doorslaggevend lijkt te zijn geweest, getuige de befaamde uitspraak: "Zestig dagen van een onrechtvaardige machthebber zijn beter dan één nacht van wetteloosheid”. Anderzijds was er het standpunt dat de umma het recht had zich te ontdoen van haar leider wanneer deze niet overeenkomstig de islam en de sharia handelde.

De kalief was weliswaar de opvolger van de Profeet, maar hij was slechts een zaakwaarnemer: hij diende het islamitische erfgoed te beheren en de voorwaarden te scheppen waaronder de sharia op de juiste wijze uitgelegd en uitgevoerd kon worden. Alleen als een kalief zelf tot de ulama zou behoren en zodanige kennis had van de sharia dat hij ijtihad-bevoegd was (zie hierboven, par. 2.1), kon hij het wereldlijke gezag verenigen met het religieuze gezag. Na de periode van Rechtgeleide Kaliefen kwam dit echter nauwelijks voor, zodat de uitleg en interpretatie van sharia steeds meer het monopolie werd van de ulama. Men zou dus kunnen spreken van een feitelijke, maar nimmer officiële scheiding van wereldlijke en religieuze macht, waarbij de wereldlijke macht in handen van de machthebbers (inclusief de kalief) lag, en de religieuze macht in handen van de ulama (Crone 2004: 394; Esposito en Voll 1996: 47; Lapidus 1975; Sedgwick 2003).

\subsubsection{BIJ DE SHIIETEN}

De kwestie over de opvolging van het leiderschap van de Profeet zorgde voor een tweedeling in de rangen van de moslims, waarbij degenen die later bekend stonden als shiieten alleen het leiderschap accepteerden van een naaste bloedverwant van de Profeet. ${ }^{5}$ Het leiderschap (imamaat) van de shiieten was gebaseerd op erfopvolging, waarbij de bloedlijn liep via de kleinzoon van de Profeet, Hoessein (zoon van Fatima, dochter van de Profeet en Ali, neef van de Profeet en tevens vierde kalief). Anders dan bij de sunnieten is de shiitische imam niet slechts een zaakwaarnemer, maar verenigt hij alle religieuze kennis in zich, hetgeen hem de status van onfeilbaarheid en almacht geeft (Khuri 1990: 106; Tamadonfar 1989: 95; Sourdel 1990: 1166-1167).

Alvorens hier nader op in te gaan past nog enige uitleg over de term imam. Het woord imam betekent letterlijk 'voorganger' en heeft meerdere betekenissen gekregen. De 
imam is in de fiqh de algemene term voor de hoogste leider der moslims. De term wordt in deze betekenis echter vooral door de shiieten gebezigd en heeft bij hen ook een eigen invulling gekregen die afwijkt van die bij de sunnieten, die voor hun leiderschap vasthielden aan de term kalief (Lambton 1990: 948). De andere betekenis van imam is die van 'gebedsvoorganger'. Deze functie kan in beginsel door iedere moslim worden vervuld: van de kalief of sultan die in de grote moskee in de hoofdstad de honderden gelovigen voorgaat in de preek tot de schaapherder die een aantal kameraden voorgaat tijdens het dagelijkse gebed ergens in de woestijn. In deze betekenis wordt de term imam ook bij de sunnieten gebruikt. Hierna zal 'Imam' (met hoofdletter) worden gebruikt als wordt gerefereerd aan de shiitische leiderfunctie.

De shiieten werden gedwongen ondergronds te gaan nadat Hoessein en zijn volgelingen door de Ummayadische kalief in de slag bij Karbala in het jaar 680 AD waren verslagen en gedood. De erfopvolging van de volgende imams leidde tot diverse schisma's en de daarbijbehorende vorming van sektes, zoals de Zaydieten, Qarmaten, Ismailieten, Alawieten, Fatimiden en Druzen. Enkele van deze groeperingen hadden gedurende enige tijd hun eigen rijken gehad, die een aantasting vormden van het primaat van het kalifaat in Bagdad, zoals de Qarmaten in Bahrein in de jaren 899-107 AD en de Fatimiden in Egypte van 969-1171 AD. In enkele gevallen duurde het rijk voort tot in de twintigste eeuw (zoals bij de Zaydieten in Jemen tot 1962, en bij de Ibadis in Oman).

De grootste gemeenschap der shiieten traceert haar Imam tot de twaalfde (en laatste) in de reeks van opvolgende Imams (vandaar hun naam Twaalvers). Deze shiitische gemeenschap is geconcentreerd in en rondom het huidige Iran. Het shiisme is vooral een esoterische religie, met een messianistische inslag. Bij de Twaalvers wordt de twaalfde en laatste Imam geacht verdwenen te zijn 'in het verborgene', vanwaaruit hij als de mahdi (verlosser) zal terugkeren om een rijk der rechtvaardigen te vestigen. Staatsrechtelijk betekent dit dat de shiieten het ondermaanse dienen te beheren als goede rentmeesters in afwachting van de komst van de mahdi. In het geval van het Safavidische rijk in Iran (zestiende tot negentiende eeuw AD) was er de stilzwijgende afspraak tussen de ulama en de wereldlijk leider (sjah) dat men zich niet met elkanders, respectievelijk religieuze en wereldlijke, taken zou bemoeien. Met de revolutie van 1979 werd de vilayat-i faqih gevestigd, hetgeen een grote staatsrechtelijke omwenteling betekende: het rentmeesterschap (vilayat) lag niet meer bij de sjah, maar bij de hoogste religieuze autoriteit ( aqih) die alle wetgeving toetst aan de sharia (Zie hierna). 


\subsection{ISLAMITISCHE STAAT: TOEPASSING VAN DE SHARIA}

De tweede voorwaarde waar een islamitische staat aan dient te voldoen is dat de sharia op enigerlei wijze van toepassing is. Waar het bestuur toekomt aan de mens, ligt het primaat van de wetgeving bij God. Hierbij is de staat volledig ten dienste van de sharia: de sharia gaat vóór boven de staat, zowel in rang als in tijd, en de staat bestaat slechts met het doel de sharia toe te passen (Coulson 1957: 49; Lambton 1981: xv). Voorstanders van de islamitische staat zijn het hier unaniem over eens. Waar echter verschil van mening over bestaat - zowel vroeger als nu - is de vraag wie bevoegd is om de sharia te interpreteren en hoeveel vrijheid men daarin heeft (zie hierboven, hoofdstuk 2).

\subsection{ONDERDANEN VAN DE ISLAMITISCHE STAAT ${ }^{6}$}

Vanwege de centrale rol van de sharia is de islamitische staat niet een natie-staat, maar een territorium waar de sharia heerst. Dit verklaart het gebruik in de fiqh van de term 'Huis (of territorium) van de Islam' (Dar al-Islam). Het Huis van de Islam is niet exclusief voor de moslims in de zin dat zij het alleenrecht hebben op het territorium, maar is wel van de moslims: zij oefenen de heerschappij uit over het grondgebied.

Dit heeft gevolgen voor de classificatie van rechtssubjecten door de sharia. Onderscheid wordt gemaakt tussen moslims en niet-moslims, en vervolgens tussen degenen die in het Huis van de Islam wonen en hen die in de rest van de wereld, het 'Huis van de Oorlog' (Dar al-Harb) wonen. Moslims die in het Huis van de Oorlog wonen, leven in een wereld waar de sharia niet van toepassing is. Zij moeten echter naar vermogen trachten om overeenkomstig de sharia te leven, waarbij de meerderheid in de fiqh meent dat zij daarbij zoveel mogelijk de wetten van die landen moeten respecteren mits zij daarmee niet in strijd handelen met de sharia.

De niet-moslims die in het Huis van de Islam woonachtig zijn, worden in twee categorieën ingedeeld: monotheïsten (joden, christenen en zoroasters), en overigen. Alleen de eerste categorie wordt erkend en zij heeft volgens de sharia een beschermde status (dhimma): in ruil voor betaling van een hoofdelijke belasting (jizya) en de erkenning van het islamitisch gezag, genieten zij een zekere mate van vrijheid en autonomie op het gebied van religie en hun religieuze familierecht. De dhimmis zijn onderworpen aan de sharia, met uitzondering van de regels die behoren tot de religie en de regels die expliciet vermeld staan in de Koran en Sunna (de regels van islamitisch familierecht, de hudud-straffen, en het verbod op alcohol en varkensvlees).

De status van de dhimma is die van tweederangs burger: hij heeft geen toegang tot hoge overheidsfuncties (ofschoon dat in de praktijk wel gebeurde), en heeft zich gedu- 
rende de 1400-jarige geschiedenis van de islam regelmatig discriminatoire maatregelen moeten laten welgevallen, zoals het dragen van speciale kleding. Ofschoon de dhimmis een bevolkingsgroep vormen die letterlijk 'onder bescherming' staat van de islam, heeft vervolging incidenteel plaatsgevonden, afhankelijk van de tijd, de plaats en de lokale heerser. 


\section{NOTEN}

1 Een van de weinige uitzonderingen is al-Ahkam al-Sultaniyya ('de Regels van Bestuur') van alMawardi (974-1058).

2 Formeel duurde de dynastie tot 1258. Halverwege de tiende eeuw AD zette echter het verval van het islamitische rijk en de macht van het kalifaat in.

3 Deze uitzonderingen trof men vooral aan in West-Afrika, waar in Marokko en Andalusië herhaaldelijk sunnitische machthebbers de titel 'heerser der gelovigen' (emir al-moeminien) of kalief gebruikten en het kalifaat in Bagdad niet erkenden. In deze regio ontstond ook het shiitische kalifaat (sic!) der Fatimiden (periode 909-1107 AD).

4 Letterlijk: 'Huis van Oorlog', aangezien de moslims in de vroege islam op voet van oorlog stonden met het gebied der ongelovigen. Later, toen er sprake was van vrede dan wel wapenstilstand, werd ook wel de term 'Huis van Verzoening' (Dar al-Sulh) gebruikt.

5 De nadruk ligt hierbij op 'naaste': de eerste sunnitische kaliefdynastieën van de Ummayaden en Abassieden ontleenden hun gezag onder meer aan het feit dat zij verwant waren aan de Profeet.

6 Voor deze paragraaf is ondermeer gebruikgemaakt van de volgende literatuur: Abu Sahlieh 1979; Berger 2001; Cahen 2002; Charfi 1987; Fattal 1958; Gervers and Bikhazi 1990; Yeor 1985. 
KLASSIEKE SHARIA EN VERNIEUWING 


\section{FAMILIE- EN ERFRECHT VOLGENS DE KLASSIEKE SHARIA}

\subsection{INLEIDING}

Het islamitische familie- en erfrecht is bij uitstek het terrein dat in detail is uitgewerkt in de klassieke sharia, en daar de kern van vormt. Niet alleen vanwege het onderwerp - dat net als in andere geloofsovertuigingen nauw verwant wordt geacht met de religie - maar ook omdat van het beperkte aantal juridische bepalingen in de Koran het merendeel deze rechtsgebieden betreffen. Deze Koranische bepalingen waren, in de historische context van de zevende eeuw, duidelijk bedoeld ter verbetering van de positie van de vrouw: de verzorgingsplicht van de man werd vastgesteld, aan het recht van de man tot verstoting en polygamie werden voorwaarden gesteld, en de vrouw kreeg voor het eerst een positie als erfgenaam. De keerzijde hiervan is dat het veertien eeuwen later niet zo makkelijk is deze regels opnieuw te veranderen en aan te passen aan de moderne tijd. Immers, volgens de orthodoxie van de islam zijn expliciete regels uit de Koran onveranderlijk. Om deze reden is het familierecht (met name het huwelijks- en echtscheidingsrecht) en het erfrecht een zeer beladen onderwerp, zowel religieus als politiek.

Dit hoofdstuk geeft een overzicht van het huwelijks-, het echtscheidings- en het erfrecht volgens de klassieke sharia. Meer recente ontwikkelingen die het familierecht in de twintigste eeuw heeft ondergaan, komen in hoofdstuk 9 ter sprake.

\subsection{HUWELIJKS-, ECHTSCHEIDINGS- EN ERFRECHT ${ }^{1}$}

Alvorens in te gaan op de regels van het familierecht eerst een korte opmerking over hun reikwijdte: de klassieke sharia-regels omtrent het huwelijk- en echtscheidingsrecht zijn uitsluitend van toepassing op moslims. Niet-moslims in moslimlanden hebben altijd hun eigen (joods, christelijk, zoroastrisch) huwelijks- en echtscheidingsrecht mogen toepassen. Vaak hadden zij ook hun eigen rechtbanken. Alleen in geval van rechtsgebieden buiten het huwelijk- en echtscheidingsrecht, zoals voogdij, adoptie en persoonsrecht, werd vaak de klassieke sharia toegepast op niet-moslims. Voor toepassing van deze regels waren de niet-moslims aangewezen op de moslimrechtbank.

Deze rechtspluraliteit is in de meeste moslimlanden met niet-moslimse minderheden tot op heden in stand gebleven. Een uitzondering is Turkije, dat in 1926 een nieuw familierecht heeft ingevoerd (gebaseerd op Zwitsers recht) dat niet religieus is en voor alle Turken geldt. 


\subsubsection{HUWELIJK}

Het huwelijk is volgens de klassieke sharia een species van de overeenkomst. Een huwelijk wordt gesloten zoals ieder andere overeenkomst: aanbod en aanvaarding door partijen, in het bijzijn van twee mannelijke moslimgetuigen. ${ }^{2}$ Toestemming van de huwelijksvoogd (wali) is bij alle rechtsscholen verplicht, met uitzondering van de Hanafieten. Tussenkomst van een religieuze, burgerlijke, rechterlijke of andere autoriteit is geen vereiste. Het huwelijk is daarom per definitie een burgerlijk huwelijk, ook al neemt het binnen de religie van de islam een bijzondere plaats in.

Juridisch zijn voor de huwelijkssluiting twee momenten van belang: het sluiten van de overeenkomst en de consummatie. Het eerste moment maakt dat het huwelijk rechtsgeldig gesloten is, het tweede betekent dat de echtelijke financiële verplichtingen opeisbaar worden. Dit onderscheid is van belang omdat deze twee momenten niet noodzakelijkerwijs op dezelfde dag plaatsvinden: vaak liggen er enkele weken of zelfs maanden tussen.

Zoals hiervoor is opgemerkt, is het sluiten van een huwelijksovereenkomst volgens de klassieke sharia een privaatrechtelijke handeling. Tussenkomst van een autoriteit of inschrijving is in de sharia geen voorwaarde voor de geldigheid van een huwelijk.

\section{Rechten en plichten van echtgenoten}

Het tweede moment dat voor de huwelijksluiting van belang is, is de consummatie van het huwelijk. Pas na consummatie gaan de financiële verplichtingen in die voortvloeien uit het huwelijk. Deze gelden alleen voor de man: hij moet de bruidsgave (mahr of sadaq) betalen, moet zijn vrouw voorzien van een 'wettige woning' (sakan shari) en is verplicht haar financieel te onderhouden (nafaqa). Zelfs als de vrouw vermogend is - de (getrouwde) vrouw is volgens de klassieke sharia beschikkingsbevoegd en handelingsbekwaam - hoeft zij niet bij te dragen in de onderhoudsverplichting die haar man jegens haar en hun kinderen heeft. Aangezien de vrouw zich het recht kan voorbehouden om op haar sociaal niveau onderhouden te worden, wordt door sommige rechtsscholen als aanvullende voorwaarde voor een geldig huwelijk wel de eis van sociaalmaatschappelijke 'gelijkwaardigheid' (kafa'a) tussen man en vrouw gesteld.

De bruidsgave (mahr of sadaq) is een geldbedrag dat exclusief eigendom is van de vrouw: deze dient dus onderscheiden te worden van de bruidsprijs (het bedrag dat de man aan de vader van de bruid geeft) en de bruidsschat (de uitzet die de bruid meeneemt naar haar echtelijke woning). Het is een vaste regel dat de man bij consummatie een klein gedeelte van de bruidsgave betaalt en dat het resterende bedrag pas opeisbaar is op het moment van ontbinding van het huwelijk door scheiding of overlijden van de man. Dit uitstel van betaling dient twee belangen: het behoedt de man ervoor impulsief van zijn vrouw te scheiden (hij dient dan immers het resterende 
bedrag te betalen) en na scheiding krijgt de vrouw het resterende bedrag dat de functie vervult van een eenmalige betaling van alimentatie (in de klassieke sharia onbekend).

Tegenover de financiële verplichtingen van de man staan de plichten van de vrouw. Deze zijn zowel materieel (huishouden, zorg voor kinderen) als immaterieel: behoeden van eerbaarheid van de echtgenoot en zijn familie, en gehoorzaamheid aan de man. De gehoorzaamheid is het gevolg van de juridische verhouding die er toe strekt dat de vrouw onder het gezag van haar echtgenoot valt. De rechtsscholen verschillen van mening over wat gehoorzaamheid inhoudt. Zij stellen het vaak afhankelijk van de sociale stand van partijen en van lokale gewoonten. Algemeen wordt aangenomen dat de vrouw niet zonder toestemming van haar man de echtelijke woning mag verlaten. Indien de vrouw ongehoorzaam is (nushuz), mag de man haar volgens de Koran (4: $34)^{3}$ tot de orde roepen, eerst door vriendelijke vermaning, dan met seksuele onthouding, en ten slotte met slaag. Bij dit laatste middel gaat de fiqh uitvoerig en gedetailleerd in op de ondergrens (bijvoorbeeld 'zacht tikje') en de bovengrens (bijvoorbeeld 'niet pijnlijk of oneerbaar' - Berger 2002).

De verplichtingen van man en vrouw zijn overigens wel afhankelijk van elkaar: als de man zijn onderhoudsplicht niet nakomt of met zijn vrouw een woning betrekt die niet voldoet aan minimale eisen (bijvoorbeeld inwoning bij de familie van de man) vervalt de gehoorzaamheidsplicht van de vrouw. Dit komt in het algemeen feitelijk tot uitdrukking doordat de vrouw haar man en de echtelijke woning verlaat en terugkeert naar haar ouderlijke woning. Daarmee is het huwelijk overigens niet ontbonden: door deze handeling zet de vrouw hoogstens de echtelijke verhoudingen op scherp.

\section{Polygamie}

Het is de man toegestaan om met maximaal vier vrouwen tegelijkertijd getrouwd te zijn. Aangezien dit expliciet staat vermeld in de Koran $(4: 3)^{4}$, wordt dit geacht een onvervreemdbaar recht te zijn. De aanstaande echtgenote mag dus wel bedingen dat haar huwelijk wordt ontbonden als haar echtgenoot een tweede vrouw trouwt, maar kan nimmer verbieden dát hij een tweede vrouw trouwt. Overigens stelt de Koran wel de eis dat de man zijn vrouwen 'billijk en gelijk' behandelt. Tegenstanders van polygamie wijzen op Koranvers 4: $129^{5}$ waarin staat dat een dergelijke billijke en gelijke behandeling ten aanzien van meer vrouwen niet mogelijk is (Nasir 1994: 26). Voor de Tunesische wetgever is dit laatste aanleiding geweest om polygamie te verbieden.

\section{Tijdelijk huwelijk}

In het shiitische recht bestaat de rechtsfiguur van het tijdelijke huwelijk (muta). Deze huwelijksvorm gold oorspronkelijk voor soldaten die in den vreemde voor enige tijd een seksuele relatie wilden onderhouden. Nu wordt een dergelijk huwelijk aangegaan voor een vooraf bepaalde periode, en eindigt door verloop daarvan, door scheiding, of door het overlijden van een van de tijdelijke echtgenoten. 


\subsubsection{ECHTSCHEIDING}

\section{Echtscheiding door de man}

De basisvorm van de echtscheiding is de verstoting (talaq), het recht van de man om eenzijdig en zonder opgaaf van redenen het huwelijk te ontbinden. Volgens de klassieke sharia is deze eenzijdige rechtshandeling in beginsel vormvrij. Maar door het uitspreken van de talaq is het huwelijk nog niet ontbonden. Eerst gaat een wachtperiode (idda) in van drie menstruatiecycli. Pas als deze periode is verstreken zonder dat de man zijn verstoting herroept, is het huwelijk definitief ontbonden. Gedurende de wachtperiode blijven de huwelijkse plichten in stand, met uitzondering van de seksuele omgang (die, wanneer zij toch plaatsvindt, wordt beschouwd als een stilzwijgende herroeping van de verstoting). Indien de man gedurende de wachtperiode zijn verstoting herroept, wordt het huwelijk hervat. Om te voorkomen dat de man hier misbruik van maakt, mag slechts tweemaal een herroeping plaatsvinden: als hij na de tweede herroeping weer een verstoting uitspreekt, is herroeping niet meer mogelijk.

\section{Echtscheiding door de vrouw}

De klassieke sharia kent aan de vrouw geen recht toe om zich zelfstandig te scheiden van haar echtgenoot. Niettemin beschikt de vrouw wel over mogelijkheden het huwelijk te (laten) ontbinden. Deze mogelijkheden verschillen per rechtsschool. We noemen de belangrijkste:

- Ontbindende voorwaarden. Volgens de Hanbalieten is het de echtgenoten toegestaan op dit gebied stipulaties op te nemen in hun huwelijkscontract. Zo zou de man zijn verstotingsrecht kunnen overdragen aan, of delen met zijn echtgenote. Ook kunnen bepaalde voorwaarden worden opgenomen die, indien vervuld, automatisch leiden tot ontbinding van het huwelijk. Een bekende voorwaarde is polygamie: als de man een tweede vrouw zou trouwen, heeft de eerste vrouw het recht haar eigen huwelijk met hem te ontbinden.

- Rechterlijke ontbinding (tatliq). De rechtsscholen zijn het er unaniem over eens dat de vrouw de mogelijkheid heeft om haar huwelijk te laten ontbinden, maar zij verschillen van mening over de gronden en de wijze waarop een dergelijke ontbinding dient plaats te vinden. De meerderheidsopvatting is dat de procedure van huwelijksontbinding dient te lopen via een rechter. Met betrekking tot de gronden verschillen de rechtsscholen vooral in de erkenning van het aantal gronden, waarbij de Malikieten de meeste mogelijkheden bieden en de Hanafieten de minste. Er bestaat dus geen limitatieve opsomming van deze gronden. De ontbindingsgrond die door alle rechtsscholen wordt erkend is de niet-nakoming van de man van zijn onderhoudsplicht jegens zijn vrouw, waarbij alleen de Hanafieten menen dat de niet-nakoming moet voortkomen uit onwilligheid van de man, niet zijn onvermogen daartoe. Andere gronden zijn onder andere een seksueel of lichamelijk gebrek bij de man, zijn langdurige afwezigheid en bepaalde vormen van leed of schade (darar) die de man de vrouw toebrengt. De interpretatie van de details (bijvoorbeeld de definities van 
leed, langdurige afwezigheid of een lichamelijk gebrek) verschilt per rechtsschool.

- Khul. Deze ontbindingsvorm, die vaak wordt vertaald als 'scheiding met wederzijdse instemming', wordt door alle rechtsscholen erkend: de vrouw verzoekt haar echtgenoot gebruik te maken van zijn verstotingsrecht, in ruil waarvoor zij dan een vergoeding aanbiedt (het meest gangbaar is het kwijtschelden van de resterende bruidsgave).

\section{Gevolgen van echtscheiding}

Het islamitische huwelijk kent alleen huwelijkse voorwaarden. Voorts heeft de vrouw na echtscheiding geen recht op alimentatie. Wel heeft zij recht op het resterende deel van de bruidsgave. De reden hiervan is dat er volgens de klassieke sharia altijd iemand onderhoudsplichtig is jegens de vrouw: tijdens het huwelijk is dat haar man, voor en na het huwelijk zijn dat haar vader, broers of andere mannelijke verwanten. De man blijft na de echtscheiding wel onderhoudsplichtig jegens zijn kinderen. Deze plicht blijft jegens zijn dochter bestaan totdat zij trouwt, en jegens zijn zoon totdat deze in zijn eigen onderehoud kan voorzien.

Ten aanzien van de kinderen maakt de klassieke sharia onderscheid tussen gezag (wilaya) en verzorging (hadana). Het gezag heeft betrekking op het algemeen toezicht op de (met name religieuze) scholing en het vermogen van het kind: dit is na de scheiding voorbehouden aan de vader. De verzorging betreft de dagelijkse verzorging en is na de scheiding het recht en de plicht van de moeder voor de kinderen zolang zij een bepaalde leeftijd nog niet hebben bereikt (de leeftijd verschilt per rechtsschool en varieert van ongeveer zeven jaar voor jongens tot tien jaar voor meisjes). Zodra de kinderen deze leeftijd hebben bereikt, gaan zij naar de vader.

\subsubsection{ERFRECHT 6}

Het erfrecht wordt vaak aangehaald als het ultieme voorbeeld van wat de sharia is en hoe zij functioneert. Volgens een uitspraak van de Profeet vormen de regels van het erfrecht 'de helft van alle kennis'. De Koranische regels, de sprekende voorbeelden uit het leven van de Profeet Mohammed, de aanpassingen die zijn gemaakt om een evenwicht tussen de erfgenamen te bewaren, en de uitgebreide casuïstiek geven dit rechtsgebied weliswaar het aanzien van een labyrint, maar worden om dezelfde reden door moslims gezien als het pronkstuk van islamitische rechtsgeleerdheid.

Het islamitische erfrecht bestaat uit twee delen: testamentair en wettelijk erfrecht. De erflater mag bij testament maximaal een derde van zijn vermogen vermaken. De klassieke sharia noemt de erfgenamen die aanspraak maken op het overige deel van de nalatenschap. Onterven bij testament is derhalve niet mogelijk.

Moslims en niet-moslims zijn geen wettelijke erfgenamen van elkaar. Een christelijke vrouw kan bijvoorbeeld niet ab intestaat erven van haar moslimse echtgenoot en hij niet van haar. Zij kan evenmin van hun kinderen - die van rechtswege moslim zijn 
- erven en zij ook niet van haar. De enige mogelijkheid om deze religieuze kloof te overbruggen is het testament: hier speelt de religie van testateur en begunstigde geen rol. De moslimse echtgenoot kan dan tot maximaal een derde van zijn vermogen aan zijn christelijke echtgenote testeren.

Het islamitische wettelijke erfrecht kent in beginsel twee soorten erfgenamen: de agnaten en de Koranische erfgenamen. Agnaten zijn alle mannelijke familieleden van de overledene; zij hadden in de pre-islamitische periode het alleenrecht op de erfenis. Met de komst van de islam is echter een nieuwe groep van erfgenamen geïntroduceerd, bestaande uit acht categorieën vrouwen en vier mannen (waarvan negen in de Koran worden vermeld en de overige drie door de fiqh zijn toegevoegd). Nog ingrijpender was de omdraaiing van de volgorde van de verdeling van de nalatenschap: eerst krijgen de Koranische erfgenamen hun deel, de rest wordt gelijkelijk verdeeld onder de agnatische erfgenamen. De introductie van vrouwelijke erfgenamen was waarlijk revolutionair en betrof de volgende vrouwen: de echtgenote van de overledene, zijn moeder, grootmoeder van vaderszijde, zussen, halfzussen zowel van moederszijde als van vaderszijde, dochters, en kleindochters van zijn zonen. Afgezien van de echtgenote betreft het hier de zussen van de belangrijkste agnatische erfgenamen (dus de dochter naast de zoon, de zus naast de broer, de moeder naast de vader, enzovoort). De erfportie van ieder van deze vrouwen is vastgesteld op de helft van wat haar mannelijke verwant in dezelfde graad (haar broer) krijgt. De uitspraak 'de vrouw erft de helft van wat de man krijgt' is daarom te algemeen. Het is namelijk zeer goed mogelijk dat een vrouwelijke erfgenaam meer krijgt dan een mannelijke. ${ }^{7}$ 


\section{NOTEN}

1 Voor deze paragraaf is onder meer gebruikgemaakt van de volgende literatuur: Coulson 1964; El Alami and Hinchcliffe 1996; Esposito 1982; Haeri 1989; Linant de Bellefonds 1965; Mallat and Connors 1990; Millot et Blanc 1987; Nasir 1990; 1994; Schacht 1964.

2 In plaats van één man mogen ook twee vrouwen optreden als getuige.

3 "De mannen zijn zaakwaarnemers voor de vrouwen, omdat God de een boven de ander heeft bevoorrecht en omdat zij van hun bezittingen uitgegeven hebben. De deugdzame vrouwen zijn dus onderdanig en zij waken over wat verborgen is, omdat God erover waakt. Maar hen van wie jullie ongezeglijkheid vrezen, vermaant haar, laat haar alleen in de rustplaatsen en slaat haar. Als zij jullie dan gehoorzamen, dan moeten jullie niet proberen haar nog iets aan te doen" (Koran 4: 34).

4 "En als jullie vrezen ten aanzien van de wezen niet juist te handelen, trouwt dan met zoveel vrouwen als jullie goeddunkt, twee, drie of vier. Maar als jullie vrezen (haar) niet rechtvaardig te kunnen behandelen, dan met één of met slavinnen waarover jullie beschikken. Dat is het meest voor de hand liggend om onrechtvaardigheid te voorkomen" (Koran 4: 3).

5 "Jullie zullen niet in staat zijn de vrouwen gelijk te behandelen, hoe graag jullie het ook zouden willen, maar geeft dan ook niet volledig toe aan jullie afkeer, zodat jullie haar alleen laten als een ongehuwde. En als jullie het weer goed maken en godvrezend zijn, dan is God vergevend en barmhartig" (Koran 4: 129).

6 Deze paragraaf is gebaseerd op Coulson 1971 en Schacht 1964.

7 Een voorbeeld is dat van de overleden vrouw, die haar echtgenoot, twee ouders en twee dochters nalaat. De erfportie van ieder van de dochters (een derde) is groter dan dat van hun vader (een kwart) of grootvader (een zesde). 
KLASSIEKE SHARIA EN VERNIEUWING 


\section{STRAFRECHT VOLGENS DE KLASSIEKE SHARIA}

\subsection{INLEIDING}

In nagenoeg alle moslimlanden waar het klassieke islamitische strafrecht van toepassing is geweest, is dit strafrecht in de loop van de negentiende en twintigste eeuw vervangen door een westerse vorm van strafrecht. Uitzonderingen zijn de Golfstaten Saoedi-Arabië, Jemen en Qatar, waar het islamitische strafrecht gehandhaafd is gebleven. Het is daarom opmerkelijk dat vanaf 1972 in ieder geval in vijf moslimlanden sprake is van de herinvoering van het islamitische strafrecht: Libië, Soedan, Pakistan, Iran en Noord-Nigeria. ${ }^{1}$

Wat in de - westerse - volksmond 'islamitisch strafrecht' wordt genoemd, omvat een zeer klein gedeelte van het gehele strafrecht. De Koran noemt slechts een vijftal delicten waarop zware lijfstraffen zijn gesteld, zoals steniging, amputatie en geseling. Voorts geeft de Koran enige richtlijnen voor een pre-islamitische procedure inzake doodslag en mishandeling. De overige misdrijven, hun delictsomschrijvingen en straffen, alsmede het strafprocesrecht, vallen onder de regelgevende bevoegdheid van de overheid (siyasa). Als er tegenwoordig wordt gesproken over (her)invoering van islamitisch strafrecht, heeft dit dus betrekking op slechts enkele delicten.

Dit hoofdstuk presenteert een overzicht van de klassieke sharia-regels van het strafrecht. $^{2}$ Later, in hoofdstuk 9, zal worden ingegaan op de rechtspraktijk van het hedendaagse islamitische strafrecht.

\subsection{STRAFRECHT VOLGENS DE KLASSIEKE SHARIA}

Het islamitische strafrecht bestaat uit drie onderdelen:

1 de hadd-misdrijven; dat zijn de vijf delicten die worden vermeld in de Koran;

2 de jinayat, ofwel het vergeldingsrecht inzake moord, doodslag en mishandeling, die ook enige procesrechtelijke regels omvat;

3 de siyasa (ook wel genoemd: tazir); de resterende misdrijven en hun straffen, alsmede het strafprocesrecht, die gezamenlijk tot de regelgevende bevoegdheid van de overheid behoren.

Deze drie onderdelen van het strafrecht zijn door de rechtsgeleerden altijd afzonderlijk behandeld en nimmer ondergebracht in een systematische theorie of strafrechtelijk systeem. De rechtsgeleerden behandelden in de fiqh slechts een zeer klein gedeelte van het strafrecht, namelijk de hadd-straffen en de jinayat. Alle overige regels behoorden tot de bevoegdheid van de overheid. Dat overheden van moslimlanden in de meeste 
gevallen westerse strafwetten hebben overgenomen is daarom niet strijdig met de sharia, tenzij deze wetten bepalingen bevatten die strijdig zouden zijn met de haddstraffen en de jinayat.

\subsubsection{HADD-MISDRIJVEN}

De klassieke sharia noemt drie instanties die zijn belast met het aanbrengen en vervolgen van hadd-misdrijven: de rechter (qadi), de instanties belast met openbare orde (politie en militairen), en de marktmeester (muhtasib). Van deze drie neemt de rechter de meest prominente positie in; de overige instanties houden zich voornamelijk bezig met misdrijven die onder de siyasa vallen.

De rechtsgeleerden spelen een ambivalente rol in het leerstuk van de hadd-misdrijven: enerzijds zijn zij degenen die aan de Koranische straffen verzwarende bepalingen hebben toegevoegd, maar anderzijds lijken zij zich er vooral op te hebben toegelegd om de toepassing van deze straffen zoveel mogelijk te beperken. Dit werd bewerkstelligd door zware procedurele voorwaarden te stellen.

Zo dient het delict strikt omschreven te zijn en moet de dader voldoen aan alle afzonderlijke delictsbestanddelen. Ook bij medepleging dient iedere pleger afzonderlijk alle delictsbestanddelen vervuld te hebben. Voorts wordt veel aandacht geschonken aan de bewijslast. Strafoplegging kan alleen plaatsvinden bij getuigenis van twee mannelijke moslimgetuigen (of voor iedere man twee vrouwen), bij overspel opgehoogd tot vier mannelijke moslimgetuigen, of bij een vrijwillige bekentenis van de dader (indien deze wordt ingetrokken komt de executie onmiddellijk te vervallen). Andersoortig bewijs wordt niet toegestaan. Alleen de Malikieten accepteren in twee gevallen aanvullend bewijs: als de verdachte ruikt naar alcohol is dat bewijs voor drankgebruik, en als een ongetrouwde vrouw zwanger is geldt dat als bewijs voor sexueel verkeer buiten het huwelijk (zina).

Ten slotte geldt het leerstuk van de dwaling (shubha): als de dader ook maar enigszins dwaalde over feiten of de strafbaarheid van zijn handelen, kan hij niet worden vervolgd voor het ten laste gelegde hadd-misdrijf (volgens de Hanafitische rechtsschool is het al voldoende dat de dader verklaart dat hij meende dat zijn handelen niet verboden was). Vandaar dat oplegging van hadd-straffen, indien de klassieke sharia strikt in acht wordt genomen, nagenoeg onmogelijk is.

De hadd-misdrijven zijn de volgende: 


\section{Diefstal (sariqa)}

De delictsomschrijving luistert zeer nauw. Het gestolen goed moet een minimumwaarde hebben (variërend van 10 tot 30 gram zilver, afhankelijk van de rechtsschool), van iemand anders zijn, dus geen gemeenschappelijk eigendom, zoals water of wild, en moet in het geheim uit een afgesloten plaats worden ontvreemd. Zakkenrollen valt hier buiten, omdat dat op de openbare weg gebeurt. De dief die op heterdaad wordt betrapt is niet schuldig aan het hadd-misdrijf, aangezien hij het goed nog niet had weggenomen. Ook verduistering en oplichting vallen niet onder het hadd-misdrijf diefstal.

De straf voor diefstal is volgens de Koran amputatie van de (rechter)hand (5:38). ${ }^{3}$ De fiqh heeft daaraan toegevoegd dat bij recidive achtereenvolgens de linkervoet, linkerhand en ten slotte de rechtervoet moeten worden geamputeerd. Volgens de shiieten geldt amputatie alleen voor de vier vingers van de rechterhand.

\section{Struikroverij (hiraba)}

Dit misdrijf betreft het overvallen van iemand op de openbare weg, al dan niet gepaard gaande met geweld. De shiieten leggen hiraba ruimer uit: volgens hen is het iedere verstoring van de openbare orde die gewapenderhand plaatsvindt.

De Koran noemt als straffen doodstraf, kruisiging, amputatie van hand en voet, en verbanning (Koran 5: 33). ${ }^{4}$ In de sunnitische fiqh is dit als volgt uitgewerkt: als alleen de weg wordt versperd en voorbijgangers worden bedreigd of als er slechts een poging tot beroving wordt gedaan, dan is de straf verbanning of opsluiting. Gaat dit alles gepaard met beroving, dan worden de rechterhand én de linkervoet geamputeerd. Vallen er doden, dan worden de rovers gekruisigd. De regel dat iedere dader aan alle delictsbestanddelen moet voldoen geldt niet bij struikroverij: als de afzonderlijke handelingen van de daders gezamenlijk voldoen aan struikroverij, krijgen zij allen dezelfde straf. De rechter heeft de vrije keuze uit een van de straffen die de Koran voorschrijft.

\section{Drinken van alcoholische dranken (shurb al-khamr)}

De Koran spreekt slechts van wijn, maar dit is in de fiqh uitgebreid tot alle alcoholische dranken. Voorwaarde is dat de drank bewust was ingenomen. Het is interessant dat de Koran het drinken van wijn verbiedt zonder daar een straf aan te verbinden (Koran 5: 90). ${ }^{5}$ Het waren de rechtsgeleerden die de straf vastlegden in de fiqh: afhankelijk van de rechtsschool is dit 40 tot 80 zweepslagen. De tenuitvoerlegging van de straf is ook nauw omschreven: de zweep dient van (zachte) koeienhuid gemaakt te zijn en de zweepslagen dienen toegediend te worden met een voorwerp onder de bovenarm van de slagarm om te voorkomen dat de slagen met volle kracht worden toegediend. Het uitgangspunt is dat de vernedering een grotere straf wordt geacht dan het toedienen van pijn. 


\section{Seksueel verkeer buiten het huwelijk (zina)}

Dit misdrijf heeft betrekking op zowel getrouwde als ongetrouwde personen. De Koran noemt als straf honderd zweepslagen (Koran 24: 2). ${ }^{6}$ De rechtsgeleerden hebben deze straf in de fiqh aanzienlijk verzwaard: honderd geselslagen voor de ongetrouwde persoon en steniging voor de persoon die getrouwd is of getrouwd is geweest (steniging geldt dus ook voor de gescheiden persoon en de weduwe of weduwnaar). De rechtsgeleerden hebben in de fiqh echter de bewijslast verzwaard: vier moslimmannen dienen ooggetuigen geweest te zijn.

In de klassieke sharia is een verkrachte vrouw niet schuldig aan zina, aangezien de seksuele gemeenschap buiten haar wil plaatsvond. Het probleem is echter dat zij dat wilsgebrek moet aantonen. Dit zal vaak ondoenlijk zijn, maar om de bestraffing af te wenden, is zij gebaat bij de zware bewijsrechtelijke voorwaarden waaraan de vier mannelijke getuigen dienen te voldoen. In het geval van de Malikitische rechtsschool (die onder meer van toepassing is in West-Afrika) geldt echter dat de zwangerschap van een ongetrouwde vrouw voldoende bewijs is voor zina. Alleen als er bijkomend bewijs is dat duidt op een verkrachting (bijvoorbeeld dat zij om hulp schreeuwde), kan bij de Malikieten ontslag van zina-vervolging plaatsvinden.

Over homoseksualiteit wordt verschillend geoordeeld: alleen de Hanafieten menen dat dit niet tot het hadd-misdrijf zina kan worden gerekend. Van de overige rechtsscholen achten de Malikieten steniging van toepassing, terwijl volgens de Hanbalieten en Shafiieten steniging alleen geldt voor de 'actieve' partner, die bovendien getrouwd (geweest) moet zijn.

Bij de shiieten gelden weer andere regels. Volgens hen vallen onder zina alle vormen van seksuele gemeenschap die niet voldoen aan de heteroseksuele, vaginale gemeenschap. Bij de shiieten geldt de hadd-straf van steniging alleen voor getrouwde personen (dus niet voor degenen die getrouwd zijn geweest), en voorts voor ongetrouwde mannen die zich schuldig hebben gemaakt aan incest, verkrachting, homoseksueel geslachtsverkeer en geslachtsverkeer tussen een niet-moslimse man en een moslimse vrouw.

\section{Ongegronde beschuldiging van seksueel verkeer buiten het huwelijk (qadhf)}

Indien iemand valselijk wordt beschuldigd van seksueel verkeer buiten het huwelijk, of als een van de vier mannelijke getuigen zijn getuigenis intrekt, dan is er sprake van een ongegronde beschuldiging. De Koranische straf is tachtig zweepslagen (Koran 24: 4). ${ }^{7}$

\section{Afvalligheid van islam (ridda)}

Dit misdrijf wordt niet met zoveel woorden vermeld in de Koran, maar is ingesteld door de fiqh. Of afvalligheid een hadd-misdrijf is, is dus omstreden, maar over de 
strafmaat zijn de rechtsscholen het unaniem eens: de doodstraf. De afvallige kan zijn straf ontlopen door zijn afvalligheid te herroepen. Afvalligheid wordt ook geacht plaatsgevonden te hebben in het geval van belastering van de Profeet Mohammed; ook daar staat de doodstraf op. In dit geval is herroeping echter niet mogelijk.

\subsubsection{VERGELDING (JINAYAT)}

In geval van moord, doodslag of mishandeling geldt in beginsel het ius talionis, het vergeldingsprincipe van oog-om-oog, tand-om-tand (qisas). In de pre-islamitische tijd leidde dit tot vetes tussen clans en stammen, die soms generaties konden voortduren. De Koran heeft hier enige beperkingen aan gesteld. Vergelding is alleen mogelijk jegens de dader (en niet jegens leden van zijn familie of clan) en geldt alleen indien er sprake is van opzet. Was er geen opzet, dan is de dader slechts aansprakelijk voor de betaling van compensatie (bloedgeld of diya). De clan waar de dadar toe behoort is tevens mede-aansprakelijk. Procesrechtelijk is er dan sprake van een privaatrechtelijke afhandeling, waarbij de rechter slechts toeziet op de juiste toepassing van de procedure. Bij de jinayat is de problematiek betreffende leerstukken als opzet, causaliteit, medeplegen en rechtvaardigingsgronden meer ontwikkeld dan bij de hadd-delicten. Het privaatrechtelijke karakter blijkt ook uit het feit dat er geen sprake is van het opleggen van straffen: de eis kan alleen vergelding (qisas) of compensatie (diya) zijn. De uitvoering in geval van vergelding is er niet minder afschrikwekkend door: doodslag, uitgestoken ogen of afgerukte ledematen worden vergolden door de dader op gelijke wijze te doden of te verminken. Voor het geval van compensatie geeft de fiqh uitvoerige opsommingen van vaste vergoedingen voor de meeste vormen van mishandeling.

\subsubsection{BELEIDSVRIJHEID (TAZIR)}

Zoals hiervoor reeds is vermeld, is de siyasa (of tazir) de restcategorie van het islamitische strafrecht. Het is wel de grootste categorie, aangezien zij alle misdrijven en strafprocesrechtelijke regels omvat die niet door de klassieke sharia worden geregeld. Het is met een beroep op deze siyasa-bevoegdheden dat de meeste moslimlanden gedurende de negentiende en twintigste eeuw een op westerse leest geschoeid wetboek van straf(proces-)recht introduceerden als hun eigen nationale strafrecht.

In geval van samenloop tussen de hadd-misdrijven en jinayat enerzijds met de siyasaregels anderzijds, gold de volgende procedure: indien een persoon werd verdacht van een hadd-delict, werd eerst de procedure van dat delict doorlopen. Wanneer de verdachte niet schuldig werd bevonden aan het hadd-misdrijf, kwam hij niet op vrije voeten, maar kwam hij in de 'gewone' strafrechtelijke procedure terecht. Een dief kon dus bijvoorbeeld worden vrijgesproken van sariqa, maar vervolgens wel veroordeeld worden op grond van het 'gewone' delict diefstal. 


\section{NOTEN}

1 In twee landen is het islamitische strafrecht wel afgekondigd, maar niet geïmplementeerd: in de Verenigde Arabische Emiraten (1978) en in de Maleisische federale staat Kelantan (1993).

2 In dit hoofdstuk is vooral gebruik gemaakt van Peters 1990; 1994; 2005 en Schacht 1964; 1986.

3 "En de dief en de dievegge, houwt hun de hand af ter vergelding voor wat zij begaan hebben, als een afschrikwekkend voorbeeld van God. God is machtig en wijs" (Koran 5: 38).

4 "De vergelding van hen die tegen God en Zijn Gezant oorlog voeren en erop uit trekken om op aarde verderf te zaaien zal zijn, dat zij ter dood gebracht zullen worden, of gekruisigd, of dat hun handen en hun voeten aan tegenovergestelde kanten worden afgehouwen, of dat zij uit het land verbannen worden. Dat is voor hen een schande in het tegenwoordige leven en in het hiernamaals is er voor hen een geweldige bestraffing" (Koran 5: 33).

5 "Jullie die geloven! De wijn, het kansspel, de offerstenen en de verlotingspijlen zijn een gruwel van satans makelij. Vermijdt die dus; misschien zal het jullie welgaan” (Koran 5: 90).

6 "De overspelige vrouw en de overspelige man, geselt elk van hen beiden met honderd geselslagen en krijgt in Gods godsdienst geen mededogen met hen, als jullie in God en de laatste dag geloven. Bij hun bestraffing dient een groep gelovigen aanwezig te zijn” (Koran 24: 2).

7 "Zij die eerbaar getrouwde vrouwen beschuldigen en dan niet met vier getuigen komen, geselt hen met tachtig geselslagen. Van hen zullen jullie nooit meer getuigenis aannemen; zij zijn verdorvenen." 


\section{ECONOMISCHE REGELINGEN VOLGENS DE KLASSIEKE SHARIA}

\subsection{INLEIDING}

Dit hoofdstuk gaat in op de klassieke sharia-regelgeving van enkele typische rechtspersonen en beginselen van economisch recht: waqf, riba, gharar en zakat. De moderne ontwikkelingen ten aanzien van het economische recht, zoals het 'islamitisch bankieren', komen in hoofdstuk 9 ter sprake.

\section{$6.2 W^{\prime}$ WQF $^{1}$}

De $w a q f$ is een religieuze stichting die het beste kan worden vergeleken met het Angelsaksische trust fund. De waqf speelde tot aan het begin van de twintigste eeuw in de moslimwereld een zeer belangrijke economische én sociale rol, aangezien met name landbouwgrond op grote schaal werd opgenomen in deze stichting teneinde fondsen op te brengen voor scholen, ziekenhuizen en moskeeën, maar vooral ook voor nabestaanden. Ofschoon de waqf in de loop van de twintigste eeuw door overheidsingrijpen aan betekenis heeft ingeboet, is haar rol nog steeds van belang.

Waqf betekent letterlijk 'vastzetting'. Zij houdt volgens de klassieke sharia in dat een eigenaar vaststelt dat een bepaald inkomen-genererend goed - boomgaard, winkel, boerderij - in de toekomst onvervreemdbaar is en dat alleen bepaalde personen het vruchtgebruik ervan mogen genieten. De begunstigden van een waqf zijn in het algemeen personen, maar kunnen ook gebouwen zijn. De waqf-gever kan bijvoorbeeld de opbrengsten van zijn in waqf gegeven landbouwgrond laten uitkeren voor de bouw van en het verrichten van onderhoudswerkzaamheden aan publieke gebouwen zoals scholen, moskeeën, ziekenhuizen, caravanserais (handelsoverslagplaatsen, tevens hotel), of een fontein voor buurtbewoners.

De $w a q f$ is een uitvloeisel van de liefdadigheidsplicht die wordt voorgeschreven door de islam (Fyzee 1974: 276): de inkomsten van het in waqf gegeven eigendom dienen ten goede te komen aan minderbedeelden. In de praktijk dient de waqf twee verschillende doelen: liefdadigheid en familiebelangen.

In het geval van liefdadigheid komt de waqf ten goede aan instituten als ziekenhuizen en scholen, of nader omschreven maar anonieme personen. Deze liefdadigheids-waqf (waqf khayri) keert niet alleen uit aan misdeelden en zieken, maar ook aan functionarissen die zich bezighouden met goede werken, zoals leraren en Koranlezers.

Bij de familie-waqf (waqf ahli) zijn de begunstigden de nakomelingen van de waqfgever, waarbij het doel is het familiekapitaal bijeen te houden en nakomelingen een vast inkomen te garanderen. De waqf dient hier vooral om de strenge regels van het 
erfrecht te omzeilen. Immers, door begunstigden aan te wijzen benoemt de waqfgever hen feitelijk als rechthebbenden van zijn vermogen na zijn overlijden, en door zijn nalatenschap in waqf te geven kan hij zijn erfgenamen beroven van hun erfenis, of sommige erfgenamen bevoordelen.Vaak is er sprake van een mengvorm: de waqf-gever geeft bijvoorbeeld zijn winkel en boomgaard in waqf met als doel dat de opbrengsten ten goede komen aan het jaarlijks reciteren van Koranverzen bij zijn graf, het onderhouden van de buurtmoskee, en het betalen van een jaarlijkse uitkering aan nader aangeduide nakomelingen.

De waqf-akten zijn zeer gedetailleerde documenten. Nadat de waqf-gever zijn eigendom in waqf heeft gegeven, kan niemand - noch hijzelf, noch zijn begunstigden of erfgenamen - daar iets aan veranderen. Het is dus zaak om zowel de verdeling van de opbrengsten als het beheer van de waqf zo nauwkeurig mogelijk vast te leggen. Daarom wordt in de akte vaak een opzichter aangewezen die is belast met de verdeling van de opbrengsten en het onderhoud van de waqf. Het is een positie die in het algemeen via erfopvolging wordt vervuld.

De onvervreemdbaarheid van de waqf blijkt uit de juridische constructie: de waqf is een eenzijdige rechtshandeling, waarbij het eigendom van een goed wordt overgedragen aan God. In de praktijk verschafte dit zekerheid voor de begunstigden, maar het had ook zijn nadelen. Aangezien een waqf onvervreemdbaar was, en de voorwaarden en verdelingen zoals neergelegd in het waqf-contract onveranderlijk en voor eeuwig waren, werd een waqf-goed feitelijk onttrokken aan het economische verkeer. In het geval van waqf-land sprak men daarom wel van 'dood land': eenmaal in waqf gegeven land kon eeuwenlang door de begunstigden worden gebruikt, maar zij konden het niet vervreemden, doen vererven of er anderszins over beschikken.

De praktijk was echter weerbarstiger dan de leer; men bedacht allerlei juridische constructies om waqf-eigendom toch te kunnen verhuren of ruilen. Niettemin nam het aantal waqfs in de loop der eeuwen alleen maar in aantal toe. In 1925 was bijvoorbeeld driekwart van de landbouwgrond in Turkije in waqfs ondergebracht; aan het eind van de negentiende eeuw gold dat voor de helft van de landbouwgrond in Algerije en voor een derde daarvan in Tunesië (Fyzee 1974: 276).

Toen duidelijk werd dat de omvang van de waqfs een obstakel vormde voor modernisering en vooruitgang, gingen in de loop van de twintigste eeuw veel moslimlanden ertoe over de $w a q f \mathrm{~s}$ op te heffen of te nationaliseren. In Egypte werden in 1952 bijvoorbeeld alle familie-waqfs opgeheven en verdeeld onder de begunstigden, en werden de liefdadigheids-waqfs onder het centrale bestuur van het Ministerie van Waqf gesteld. 


\subsection{RIBA EN GHARAR}

Ofschoon handel in de islam zeker geen vies woord is - de Profeet was zelf immers een geslaagd koopman - maakt de Koran nadrukkelijk onderscheid tussen winst uit onderneming en winst uit geldlening ('woeker'). ${ }^{2}$ De Koran en de Profeet verkondigden eerlijke handel, waarbij zij woeker en misbruik van marktposities scherp veroordeelden. In moderne tijden is het argument gebruikt dat dergelijke praktijken het risico met zich meedragen dat overheden, ondernemers en consumenten zwaar in de schuld komen te staan bij de financiers, wat de economie niet ten goede komt (Siddiqi 1983: 69). Dat de Koran eerlijkheid en rechtvaardigheid voorschrijft in het economisch verkeer ${ }^{3}$ heeft een expliciete uitwerking gekregen in het contract- en handelsrecht. Hierin staan twee verboden centraal: riba (woeker, ofwel ongerechtvaardigde verrijking), en gharar (onzekerheid ofwel speculatie).

Riba wordt vaak vertaald met rente. Dat is niet geheel juist. Waar het om gaat is dat er geen ongerechtvaardigde verrijking plaatsvindt welke voortvloeit uit "een ongelijkheid in de tegenwaarden van een transactie” (Ansari-Pour 1995: 179; Saleh 1992: 16). In het geval van geldlening is het vragen van rente derhalve inderdaad verboden, aangezien de geldschieter geen prestatie levert die vermeerdering van de geleende geldsom zou rechtvaardigen. Aangezien dit strenge verbod geldverkeer onmogelijk maakt, zijn in de fiqh de zogenoemde trucs (hiyal) geformuleerd die effectief tot een geldlening-metrente kunnen leiden. Bekend is de 'dubbele koop': de lening van A aan B wordt verpakt als de verkoop van B's ezel aan A voor 100 dinar, en onmiddellijke terugkoop voor 110 dinar, waarbij de betaling door B echter pas over een jaar voldaan dient te worden.

Het verbod op gharar heeft betrekking op het vermijden van elke onzekerheid in een handelstransactie. Dit heeft geleid tot strikte eisen die de fiqh stelt aan de vaststelling van moment van betaling en levering, vaststelling van koopsom en valuta, en de omschrijving van de koopwaar. Op deze gronden zijn moderne juridische constructies als hypotheek, verzekering en aandelenspeculatie volgens de klassieke sharia verboden.

Naast het verbod op riba en gharar is het volgens de klassieke sharia voorts niet toegestaan te investeren in goederen zoals varkensvlees, gokpraktijken, alcohol en tabak. Deze goederen zijn aangemerkt als ‘verboden' (haram).

Om riba en gharar te vermijden, nemen financieringstransacties volgens de klassieke sharia vaak de vorm aan van een vennootschap tussen geldschieter en geldlener, waarbij beide partijen samen delen in de winsten, maar ook in de verliezen. Twee vennootschapscontracten werden hiertoe het meest geschikt bevonden: de gewone vennootschap (musharaka) en de commanditaire vennootschap (mudaraba). Daarbij delen de vennoten hun winst (en verlies) in procenten, niet in vastgestelde aandelen. 
Moderne 'islamitische economen' menen dat een dergelijk partnerschap, dat eenzijdige schuldenlasten voorkomt, niet alleen gezond is voor de economie, maar ook voor de maatschappij als geheel (Siddiqi 1983: 69).

Naast deze twee contracten kent de klassieke sharia nog een aantal andere contractsvormen, die samen het basismateriaal vormen voor het hedendaagse islamitisch bankieren. Op grond van de twee islamitische verboden en deze islamitische contracten worden moderne contractsvormen geconstrueerd, zoals bijvoorbeeld de 'islamitische' hypotheek, verzekering, creditcard en turnkey-projecten. ${ }^{4}$

\subsection{ZAKAT}

Zakat is het afdragen van een percentage van het eigen vermogen aan minderbedeelden en behoort tot de vijf religieuze plichten van iedere moslim (de andere vier zijn: geloof in de ene God en Zijn Profeet, gebed, vasten tijdens ramadan en pelgrimage naar Mekka). Het is een van de belangrijkste instrumenten van de islam in zijn streven naar een gelijke verdeling van welvaart. In de vrijwillige vorm kan men zakat vertalen met 'aalmoes' en in de verplichte vorm met 'belasting'. Voor vrijwillige zakat wordt de term sadaqa gebruikt, of zakat al-fitr als het gaat om de aalmoezen en donaties die moslims traditioneel geven tijdens de vastenmaand ramadan.

In de Sunna komt zowel de vrijwillige als de verplichte zakat voor. In navolging van de Profeet echter, die de zakat verplicht had gesteld en liet innen door speciaal daartoe aangestelde functionarissen, geldt volgens de fiqh een algemene plicht voor de moslimheerser om de zakat te innen. Over de wijze waarop dat gedurende de geschiedenis van de islam in zijn werk is gegaan, is zeer weinig bekend, evenals over de herverdeling van de zakat-inkomsten (Zysow 2002: 409). Ook is niet bekend of, en in welke mate, de staat kan optreden als substituut voor de acht categorieën van personen aan wie de zakat ten goede moet komen (Tyan 1999: 171).

In de fiqh heeft de zakat het gemengde karakter gekregen van een individuele religieuze plicht en een wijze van belastingheffing. Vanuit religieus perspectief wordt de zakat beschouwd als onlosmakelijk deel van de verering van God, en vaak in één adem genoemd met het gebed, één van de vijf zuilen van de islam. Het voldoen aan de plicht tot zakat wordt beschouwd als een vorm van reiniging van de ziel. Het niet voldoen van de zakat is, in ieder geval in de vroege islam, daarom aangemerkt als een vorm van afvalligheid (Tyan 1999: 171).

Als vorm van belasting wordt de zakat gewoonlijk geclassificeerd als belasting op vermogen, niet zozeer op inkomen. Dit is niet geheel correct. De fiqh bestempelt de zakat als een belasting op goederen die 'groei' vertegenwoordigen (zoals oogst en gedolven ertsen), of bijdragen aan die groei (zoals vee, handelswaar, en goud en 
zilver) (Syzow 2002: 410). Een minderheid van de fiqh-geleerden meent dat het gehele vermogen van een persoon kan worden aangeslagen voor zakat, maar de meerderheid is van mening dat de zakat alleen kan worden geheven op de specifieke goederen die hiervoor zijn genoemd. Deze goederen worden vermeld in de Koran, en vertegenwoordigen tevens de belangrijkste bronnen van inkomsten en vermogen in het zevendeeeuwse Arabië. Overigens bestaan er in de fiqh zeer uiteenlopende interpretaties over de exacte vaststelling van de goederen (volgens de shiieten heeft 'oogst' alleen betrekking op graan, rogge, dadels en rozijnen; volgens sommige Hanafieten vallen paarden niet onder 'vee'; de Hanbalieten menen dat 'opbrengsten uit mijnen' ook betrekking hebben op petroleum). Eveneens verschillen de interpretatie van de berekening van de zakat (aftrek van schulden, verrekening van mede-eigendom, enz.), en van het moment dat geïnd kan worden (voor of na het oogsten, plukken, slachten, enz.). De berekeningen werden daardoor zeer complex en in hoge mate casuïstisch. In het algemeen varieerde de zakat in percentages van 2 tot 20 procent.

De Koran noemt acht categorieën van personen aan wie de zakat ten goede moet komen (Koran 9: 60): armen, misdeelden, zakat-inners, bekeerlingen, slaven die zichzelf niet kunnen vrijkopen, schuldenaars die hun schulden niet kunnen voldoen, degenen die zich actief inzetten (zowel vreedzaam als gewapenderhand) voor 'de zaak van God', en reizigers. 


\section{NOTEN}

1 In deze paragraaf is onder meer gebruikgemaakt van de navolgende literatuur: Baer 1997; Barbar and Kepel 1982; Barnes 1986; Behrens-Abou Seif 1994; Deguilhem 1995; Fyzee 1974.

2 Koran 2: 275: “(...) Maar God heeft de koophandel vergund gemaakt en de woeker verboden (.....”

3 De Koran geeft de bedelaars en armen het recht op een aandeel in het vermogen van de rijken (70: 24), roept op tot bescherming van de zwakken en behoeftigen (2: 177, 4:127) en eist billijkheid en eerlijkheid in handel (17: 35, 26: 181-183).

4 Zie voor de gedetailleerde uitwerking van deze contractsvormen: www.islamic-finance.net; www. islamic-banking.com; http://muslim-investor.com. 


\section{RECHTSVINDING EN ACTOREN IN DE MODERNE TIJD}

\subsection{INLEIDING}

De overheden van de moderne moslimlanden zijn tot op zekere hoogte succesvol geweest in het incorporeren van de schriftgeleerden (ulama) in het staatssysteem. Maar veel ulama houden heden ten dage nog steeds vast aan hun onafhankelijkheid ten opzichte van de overheid. Nieuw is echter dat zij in hun rol als hoeders van de sharia sedert het einde van de negentiende eeuw steeds meer concurrentie hebben gekregen van nationale wetgevers en rechters, én van leken. Niet alleen eigenden dezen zich de zeggenschap toe over de sharia, maar ook over de interpretatie daarvan, waarbij zij vaak nieuwe rechtsbronnen en methodes van rechtsvinding formuleerden.

Deze ontwikkeling loopt parallel met het vraagstuk van de mogelijkheid en de wenselijkheid van aanpassing van de klassieke sharia aan de moderne tijden. De koloniale bezetting van veel moslimlanden was een belangrijke katalysator voor deze discussie. De nationalistische bewegingen in de moslimlanden stonden bijna zonder uitzondering modernisering naar westers model voor. De ulama reageerden hier wisselend op. Sommigen meenden dat het westerse model haaks stond op de eigen, islamitische samenleving. Anderen, zoals de invloedrijke Egyptenaar Muhammed Abduh (18491905), meenden dat modernisering juist niet strijdig was met de islam (Rahnema 1994). De vraag was echter of men modernisering naar westers model op islamitische wijze moest onderbouwen, of dat de sharia een zelfstandige moderniseringsbron was, die wellicht tot andere uitkomsten kon leiden dan het westerse model. Deze verschillende uitgangspunten leidden tot zeer uiteenlopende interpretaties.

\subsection{NATIONALE WETGEVERS: MODERNISERING (NA CA. 1850)}

De nationale wetgevers van moslimlanden hebben vanaf de tweede helft van de negentiende eeuw diverse juridische moderniseringen doorgevoerd, voornamelijk langs drie wegen: (1) adoptie van westers recht; (2) codificering van islamitisch recht; (3) nieuwe vormen van rechtsvinding.

\section{Adoptie van westers recht}

De meeste moslimlanden voerden diverse westerse wetten en rechtssystemen in. Vele van deze landen stonden onder westers koloniaal bewind, maar ook het Ottomaanse Rijk nam westerse wetten integraal over als onderdeel van zijn eigen moderniseringsproces (Hodgson 1977). Het Italiaanse strafrecht, het Franse burgerlijke recht en het Duitse handelsrecht waren daarbij belangrijke voorbeelden. 
Naast de invoering van westerse wetten was er sprake van vermenging van westerse en islamitische rechtsstelsels. Dit was met name het geval in Brits-Indië, waar de vermenging van Angelsaksisch en islamitisch-Indiaas recht de naam Anglo-Mohammedan Law kreeg. Een zelfde mengeling van rechtsstelsels vond plaats in de Franse kolonie Algerije.

\section{Codificering van islamitisch recht}

Vanaf halverwege de negentiende eeuw werden voor het eerst in de geschiedenis van de islam bepaalde rechtsgebieden van de klassieke sharia gecodificeerd naar westers wetgevingsmodel. De Ottomanen codificeerden bijvoorbeeld het islamitische burgerlijke en handelsrecht (1877) en later het islamitische familierecht (1917). Bij deze codificaties liet de Ottomaanse wetgever zich vooral leiden door de prevalente mening van de Hanafitische rechtsschool. In de periode tussen 1920 en 1960 codificeerden nagenoeg alle moslimlanden hun islamitische familierecht. Vanaf de zeventiger jaren werden in enkele moslimlanden ook andere rechtsgebieden van de klassieke sharia in wetboeken ondergebracht. Deze codificaties golden alle als nationaal recht met als gevolg dat deze wetgevingen allen 'islamitisch' heetten, maar onderling konden verschillen.

\section{Nieuwe vormen van rechtsvinding}

Voor de codificatie van de nationale islamitische familiewetgeving werden door de nationale wetgevers nieuwe vormen van rechtsvinding toegepast, die niettemin waren gebaseerd op de klassieke sharia. Deze methoden werden met name ten dienste gesteld van de verbetering van de positie van de vrouw. In paragraaf 9.1 (moderne ontwikkelingen in het familierecht) zal daar uitgebreid op ingegaan worden, zodat hier slechts drie methoden kort genoemd zullen worden:

- de hernieuwde toepassing van de zelfstandige interpretatie (ijtihad), maar nu door de nationale wetgever;

- een ruimere interpretatie van de fiqh: de wetgevers achtten zich niet meer beperkt tot de prevalente opvatting van één enkele rechtsschool, maar gaven zichzelf de vrijheid een keuze te maken uit het gezamenlijke corpus van alle vijf rechtsscholen;

- toepassing van siyasa in de vorm van allerlei administratief- en procesrechtelijke regels om regels van de klassieke sharia niet inhoudelijk, maar wel in hun uitvoering aan te passen.

\subsection{NATIONALE WETGEVERS: ISLAMISERING (VANAF CA. 1970)}

Sinds de jaren zeventig zijn de nationale overheden van moslimlanden in toenemende mate onder druk komen te staan van het islamitisch activisme. Een van de eisen die aan de overheden werden gesteld was de invoering van de 'sharia'. In de meeste moslimlanden (met enkele uitzonderingen, zoals Saoedi-Arabië) was de sharia immers beperkt tot het familierecht. De roep om islamisering van de nationale wetgeving 
kwam vooral uit de hoek van islamitische activisten en traditionele kringen van de ulama. Het monopolie op regelgeving lag echter bij de nationale overheid, die in het algemeen zeer terughoudend was in het toegeven aan deze eisen. Slechts een enkele keer werd daadwerkelijk sharia-geïnspireerde wetgeving ingevoerd, hetzij alleen op één specifiek rechtsgebied, hetzij op een breder terrein. Voor het overige volstonden veel moslimlanden met verwijzingen in de grondwet naar de sharia als bron van wetgeving of naar de islam als staatsgodsdienst.

Bij de verwijzing naar 'sharia' als bron van wetgeving is vooral de formulering van de grondwetsbepaling van belang: betreft het 'de beginselen' van de sharia of 'de' sharia zelf, en zijn deze 'een bron' of 'de enige bron' van nationale wetgeving. Het is nog onduidelijk welke invloed deze grondwetswijzigingen op langere termijn zullen hebben. Afgezien van enkele radicaal-islamitische landen, zoals Iran, Soedan, Pakistan en Afghanistan onder de Taliban, lijkt de invloed van deze grondwettelijke bepalingen tot op heden gering te zijn. Enerzijds omdat de wetten die sindsdien zijn afgekondigd geen kenmerken hebben die afwijken van 'westerse' of seculiere regelgeving. ${ }^{1}$ Anderzijds omdat vooral de hogere rechtscolleges een matigende invloed hebben op de interpretatie van dergelijke grondwetsartikelen.

\subsection{RECHTERS}

Wanneer de sharia wordt ingevoerd als nationaal recht, valt de interpretatie ervan toe aan de nationale rechtspraak. De traditionele rol van de ulama als hoeders van de sharia is dan voorbehouden aan rechters. De rechterlijke macht is in de meeste moslimlanden ingericht naar westers (vooral Frans en Angelsaksisch) model. Er bestaat derhalve de neiging om de als nationale wet gecodificeerde sharia op een legalistische wijze te benaderen (Botiveau 1993; Brown 1997). Anders dan in de rechtspraktijk tot in de negentiende eeuw, waarin rechters op het gebied van de sharia regelmatig advies inriepen van ulama en muftis, geniet de moderne rechtbank onafhankelijkheid in haar interpretatie van de sharia. Deze onafhankelijke rol van de rechtbank betekent dat de rechters zich ook het recht op ijtihad toekennen. Dat is op zichzelf revolutionair te noemen: niet alleen dát ijtihad wordt beoefend, maar dan ook nog door juristen die geen ulama zijn. In dit verband is wel gesproken van een "secularisering van het islamitisch recht” (Bälz 1998).

Een voorbeeld hiervan is een uitspraak van de Pakistaanse Federal Shariat Court, die bepaalde dat de strafbedreiging van steniging voor het misdrijf overspel niet in de Koran stond vermeld en dat oplegging derhalve niet verenigbaar was met de Pakistaanse Grondwet, die de Koran en Sunna als rechtsbron noemde. Een ander voorbeeld is het Egyptisch Constitutioneel Hooggerechtshof, dat in een aantal arresten heeft bepaald dat de Egyptische wetgever niet alleen de bevoegdheid tot siyasa heeft, maar ook tot ijtihad, waarbij het tevens uitvoerig omschreef hoe ver de wetgever mag 
gaan in de toepassing van ijtihad.

Het rechterlijk monopolie op de interpretatie van de gecodificeerde sharia heeft zowel een liberale als conservatieve uitwerking. De rechters die de sharia conservatief uitleggen zijn vooral geconcentreerd in de lagere rechtscolleges, en de liberale rechters in de hogere. Er zijn echter ook uitzonderingen: zo bepaalde de Egyptische Hoge Raad in 1996 dat een hoogleraar in Koranstudies zich in zijn academische geschriften zodanig afwijkend van de orthodoxe islamitische leer had uitgelaten, dat hij tot afvallige werd verklaard.

\subsection{IJTIHAD-LEKEN}

\section{Vernieuwing en herleving van de sharia}

Met de opkomst van het islamitisch politiek activisme in de jaren zestig en zeventig van de twintigste eeuw heeft zich een nieuwe concurrent aangediend op het gebied van de sharia-interpretatie: de leek. In toenemende mate eigenen individuele moslims zich het recht toe op interpretatie van de sharia, zonder dat zij zich gehinderd voelen door de methodieken en vastgelegde interpretaties van 1400 jaar theologische en juridische wetenschap, omdat deze worden beschouwd als te beperkend voor de toepassing van de klassieke sharia in de moderne tijd. Deze leken zijn van diverse pluimage: van liberale moslim-intellectuelen tot conservatieven, of zelfs extremisten zoals Osama bin Laden. Met name de invloed van conservatieve leken, die zware kriktiek uiten op de huidige regimes, leidt in politiek opzicht tot de bijzondere situatie dat de seculiere overheden en de ulama meer naar elkaar toe trekken in hun verzet tegen deze vorm van islamitische oppositie (Ayubi 1991).

In het navolgende blijven de militante extremisten buiten beschouwing (bij hen dient de ijtihad in het algemeen tot rechtvaardiging van hun gewelddadige acties en niet tot een bepaald maatschappelijk model), en richten wij ons op degenen die vernieuwing of herleving van de sharia bepleiten (Esposito 1998). Herleving van de sharia wordt vooral bepleit in conservatieve kringen en duidt op de invoering van de sharia 'zoals zij was'. Hieraan kleeft het praktische probleem dat dit vooral betrekking heeft op het utopische model van een moreel hoogstaande samenleving. Onder de voorstanders van de herleving van sharia zijn praktische suggesties en modellen derhalve schaars. Ook over de bevoegdheid tot ijtihad wordt zeer terughoudend gedacht.

Dit is anders bij de voorstanders van de vernieuwing van de sharia. Een belangrijke rol wordt hierbij toegekend aan de ijtihad. Men bepleit dat moslimgeleerden weer het recht moeten hebben ijtihad te beoefenen zoals de eerste generaties moslimgeleerden dat deden. Deze nieuwe methoden van rechtsvinding hebben verschillende gradaties, waarvan er hierna enkele worden genoemd (zie onder meer An-Naim 1990; Ayubi 1991; Berger 1999b; Kurzman 1998). 
Aan de conservatieve kant van het spectrum staan degenen die menen dat men ijtihad niet moet opvatten als de vrijheid om opnieuw de Koran en de Sunna te interpreteren, maar als de vrijheid om keuzes te maken binnen het gehele fiqh-corpus, zonder beperkt te zijn tot één rechtsschool of één heersende opvatting. Dan zijn er degenen die menen dat de hedendaagse moslimgeleerde het recht moet hebben ijtihad te beoefenen op de wijze waarop zijn voorgangers dat deden. Dat wil zeggen dat de tekstuele en methodologische bronnen hetzelfde blijven, maar dat de rechtsvinding tot andere resultaten kan leiden vanwege nieuwe tijden en omstandigheden. Weer anderen gaan verder in deze opvatting door te betogen dat ook een andere visie op teksten en methodologie mogelijk moet zijn: de methodes van rechtsvinding zijn immers ook ontwikkeld door de mens, zo wordt geredeneerd, dus zou ook aan de hedendaagse generaties het recht moeten toekomen om dat opnieuw te doen. Ten slotte zijn er diegenen die de heilige teksten zelf - Koran en Sunna - niet als letterlijk te nemen teksten benaderen. Uitgangspunt is dat de Koran het Woord van God is, en in die zin onveranderlijk, maar voorstanders van deze benadering willen hun hernieuwde wetgevende arbeid baseren op de geest van de Koran in plaats van de letter.

In veel moslimlanden heeft het islamitisch activisme wellicht niet geleid tot concrete juridische en politieke resultaten, maar heeft het er wel voor gezorgd dat op vele maatschappelijke terreinen het islamitische discours de overhand heeft gekregen. In landen die een seculier staatsbestel kennen, zoals Egypte, is het religieuze reveil van de islam toonaangevend geworden, of op zijn minst een maatstaf waarmee rekening moet worden gehouden. Films en literatuur zijn kuiser en conservatiever dan dertig jaar geleden, net als kleding, en in alle academische disciplines is de islamitische kijk op het onderwerp een relevant onderwerp van studie geworden. De moslimorganisaties die met hun sociaal-maatschappelijke werk op het gebied van gezondheidszorg, onderwijs, welzijnswerk een belangrijke rol spelen - terreinen waar de overheid tekortschiet - geven de islamitische dimensie concrete inhoud. Islamisering, kortom, gebeurt niet alleen van staatswege, maar vindt in 'het maatschappelijk middenveld' een belangrijke medespeler (Ayubi 1991; Roy 1994). Twee belangrijke voorbeelden van de wijze waarop dit gebeurt zijn de vrijwillige toepassing van de sharia op het dagelijks leven, en het particulier initiatief tot islamitisch bankieren. Beiden zullen hierna kort worden besproken.

\section{Sharia als bron voor individuele leefregels}

Deze vorm van sharia manifesteert zich op zowel individuele als collectieve schaal. De vrome moslim die zich wil houden aan de voorschriften van de sharia kan zich beperken tot de religieuze voorschriften, maar hij kan zich ook willen houden aan de regels van de sharia inzake familierelaties, contracten en handel. Het nationale recht moge hem voorschrijven zijn auto te verzekeren, de bank kan van hem in ruil voor een lening een hypotheek op zijn huis verlangen, de belastingdienst kan hem een aanschrijving sturen - maar de gelovige moslim wil steeds vaker weten wat de opvatting van de 
sharia is over deze onderwerpen. In toenemende mate gaan moslims te rade bij een rechtsgeleerde of een mufti. De fatwa-sites op het internet zijn een indicatie voor de populariteit van dit middel om het dagelijks leven in overeenstemming te brengen met de sharia. De toetsing aan de sharia vormt voor deze moslims een leidraad in het dagelijks leven en heeft daarom vooral betrekking op persoonlijke, sociale en familierechtelijke omgangsvormen. Wanneer deze moslims de uitleg van de sharia niet in overeenstemming achten met de maatschappij waarin zij leven, kan dat tot gevolg hebben dat zij zich aan de van staatswege opgelegde regels en instituten gaan onttrekken (Berger 1999a; Masud et al. 1996; Skovgaarden-Petersen 1997). Deze ontwikkeling speelt ook in toenemende mate bij moslims in Europa (Roy 1994; 2003).

\section{Sharia als bron van particuliere financiering}

Sedert de jaren zeventig van de twintigste eeuw heeft de toepassing van islamitischfinanciële transacties ('islamitisch bankieren') een hoge vlucht genomen, niet alleen als economische activiteit, maar ook in de regelgeving. Paragraaf 9.3 gaat nader in op de juridische achtergronden van het islamitisch bankieren. Opvallend is dat deze regelgeving vooral plaatsvindt op particulier initiatief (uitzonderingen zijn Pakistan en Iran). Niet de nationale wetgever, maar particuliere instellingen - lokale en ook internationale banken - stellen zelf aan de hand van de klassieke sharia vast hoe men in deze tijd op islamitische wijze financiële transacties dient uit te voeren. Deze manier van bankieren blijkt in de meeste moslimlanden bovendien een gat in de markt te zijn: in plaats van de grote, bureaucratische banken die vaak geen krediet verstrekken aan particulieren, zijn er financiële instellingen die de particulier kredieten verstrekken tegen goede voorwaarden. Niet alleen is de kredietverlening een praktijk die uitgebreid in de klassieke sharia is vastgelegd, het predikaat 'islamitisch' is vaak al voldoende om het vertrouwen van de kleine rekeninghouder te wekken (Bahaa-Eldin 1999). 


\section{NOTEN}

1 Een voorbeeld is het nieuwe Egyptische Wetboek van Handelsrecht van 1999, dat aansluit bij de meest geavanceerde moderne financiële transacties, en tevens in overeenstemming is verklaard met de sharia. 
KLASSIEKE SHARIA EN VERNIEUWING 


\section{MODERNE THEORIEËN OVER ISLAMITISCHE STAATSVORMEN}

\subsection{STAATSVORMEN IN DE NEGENTIENDE EN TWINTIGSTE EEUW}

\section{Van kolonie en mandaat naar republiek en monarchie}

Bij de staatsvorming van de moslimlanden vanaf het einde van de negentiende eeuw kunnen drie chronologische processen worden onderscheiden: dekolonisatie, seculiersocialisme en islamitisch activisme.

Bijna alle hedendaagse moslimlanden - met uitzondering van enkele, zoals Turkije, Saoedi-Arabië, Oman, en tot op zekere hoogte ook Iran en Afghanistan ${ }^{1}$ - zijn gekoloniseerd geweest door Europese grootmachten. Het ontstaan van onafhankelijke (moslim)staten dateert vanaf het begin van de twintigste eeuw, maar vooral van na de Tweede Wereldoorlog, toen het dekolonisatieproces versneld op gang kwam.

De meeste van deze nieuwe moslimstaten namen na hun onafhankelijkheid de staatsvorm van een republiek aan, met een sterk seculiere en socialistisch-georiënteerde ideologie. (Dit verschijnsel bleef overigens niet beperkt tot moslimlanden, maar was kenmerkend voor de meeste nieuwe, postkoloniale staten.) Deze moslimlanden introduceerden in hun nieuwe grondwetten een rechtsstaat die grotendeels was gebaseerd op het westerse model (vaak dat van de voormalige kolonisator) en westerse wetgeving. Er werd bovendien in veel gevallen voor een sociaal-democratisch staatsmodel gekozen, met gratis onderwijs en gezondheidszorg en waarin beroepsgroepen werden ondergebracht in staatsvakbonden. De grondwetten schreven allemaal parlementaire en presidentiële verkiezingen voor.

Op dit moment noemen de meeste moslimlanden zichzelf nog steeds een republiek. Negen landen zijn koninkrijken of prinsdommen (emiraten). ${ }^{2}$ Koninkrijken ontstonden aan het begin van de twintigste eeuw, in navolging van het Europese voorbeeld - hetzij als voortzetting van reeds bestaande dynastieke machtsstructuren (zoals Egypte, Marokko en diverse Golfstaten), hetzij als nieuwe staatsvorm (zoals Jordanië en Irak in 1920, Libië in 1928, Saoedi-Arabië in 1932). De twintigste eeuw heeft overigens een toename van het aantal republieken in moslimlanden te zien gegeven. Door revoluties is er een einde gemaakt aan de koninkrijken Egypte (1952), Libië (1956) en Irak (1958), aan het imamaat Jemen (1962) en aan het shahdom Iran (1979). Tevens heeft het uiteenvallen van de Sovjetunie geleid tot een aantal nieuwe onafhankelijke moslimrepublieken in Centraal-Azië. 


\subsection{MODERNE THEORIEËN OVER DE ISLAMITISCHE STAAT}

De 'islamitische' staat is een modern concept dat dateert van het begin van de twintigste eeuw. De term 'staat' geeft al aan dat het om een nieuw idee gaat dat aansluiting zoekt bij het begrip 'staat' dat dateert van de negentiende eeuw. Met betrekking tot het 'islamitische' van deze staat lopen de meningen en interpretaties echter aanzienlijk uiteen, niet in de laatste plaats omdat de sharia hier weinig houvast in geeft over de islamitische staat.

In de theorieën van moderne moslimdenkers over de islamitische staat staat het leiderschap centraal. Hier doet zich het bijzondere verschijnsel voor dat de theoretici zich voornamelijk baseren op de zuivere leer van de islam, waartoe ook de praktijk van de Profeet en de Rechtgeleide Kaliefen behoort (Madelung 1990: 1164). De staatsrechtelijke praktijk van de daaropvolgende dertien eeuwen is voor de hedendaagse theorievorming niet interessant. De moderne theoretici richten zich evenmin op de functie van de kalief. Zoals eerder is vermeld, is er sedert de afschaffing van het kalifaat in 1924 nimmer een serieuze oproep tot restitutie van het kalifaat geweest. Wel bestuderen de moslimdenkers de procedure op grond waarvan de eerste kaliefen zijn verkozen, en de mogelijkheden tot afzetting. Een ander onderdeel van de islamitische staat waar de moderne theoretici zich op richten, is de toepassing van de sharia.

Voorstanders van de islamitische staat zijn het er unaniem over eens dat deze zich primair kenmerkt door de sharia als basis van de regelgeving te hanteren. De staat dient volledig ten dienste van de sharia te staan. Waar echter - zowel vroeger als nu - verschil van mening over bestaat is wie bevoegd is om de sharia te interpreteren en hoeveel vrijheid men daarin heeft (zie hiervoor, hoofdstuk 2).

In het moderne denken over de islamitische staat speelt bovendien een tweede verschil van mening, namelijk over de wijze waarop hij tot stand moet komen. Het probleem is immers niet de sharia zelf - die is, als goddelijk plan, eeuwig en altijd aanwezig - maar de toepassing ervan. Dienen de gelovigen zelf de sharia na te leven, zodat er vanzelf een islamitische samenleving ontstaat, of dient de sharia van staatswege te worden opgelegd? Met andere woorden: is de afkondiging van de islamitische staat het begin- of het eindpunt van de sociaal-rechtvaardige samenleving zoals God die heeft bedoeld?

In de moderne theorievorming over de islamitische staat kan men grofweg vier stromingen (van conservatief naar liberaal) benoemen:

1 absolute theocratie;

2 islamitische semi-democratie;

3 islamitische democratie;

4 seculiere democratie, islamitisch beredeneerd. 


\section{Absolute theocratie}

Volgens deze visie ligt alle soevereiniteit bij God alleen (hakamiya li-Llah) en is iedere vorm van menselijke keuzevrijheid ten aanzien van regelgeving en bestuur uitgesloten. De ideale samenleving is reeds gedicteerd door God in de vorm van de sharia, zodat hieraan slechts uitvoering en navolging gegeven dient te worden. Aanvullende wetgeving is niet aan de orde, hoogstens interpretatie van de sharia door rechtsgeleerden. Dit model van een "heilige staat die de menselijke wil uitsluit" (Ahmed 1987: 87 e.v.) is vooral een utopisch model dat wordt uitgedragen door zeer traditionele ulama, die iedere vorm van democratie, secularisme of laïcisme categorisch afwijzen. Kenmerkend is dat zij zich over de praktische invulling van een dergelijke staat - moeten er politie, rechters en bestuurders zijn, en zo ja, hoe worden zij dan benoemd, en door wie? - vaak niet uitlaten.

\section{Islamitische semi-democratie}

Veel omvangrijker in aanhang is de stroming die onderscheid maakt tussen de wettelijke grondslag van de islamitische staat enerzijds en het bestuur anderzijds. De soevereiniteit van God is vervat in de sharia, die nagevolgd dient te worden door de gelovigen (inclusief hun leiders) en waar niet aan mag worden getornd. Ten aanzien van het bestuur van de islamitische staat is er echter wel ruimte voor vrijheden. Hierbij spelen de beginselen 'beraadslaging' en 'consensus' een belangrijke rol: men zou kunnen spreken van vormen van democratie. De aanhangers van deze zienswijze zijn overigens zeer terughoudend als het gaat om vrijheid in de wijze van benoeming van bestuurders en inspraak van het volk in bestuursaangelegenheden.

Een typerend voorbeeld van deze denkwijze is Mawdudi, de oprichter van de Pakistaanse islamistische beweging Jamaat-i-Islami. Hij staat een 'theo-democratie' voor, waarin weliswaar plaats is voor wetgevende, rechtsprekende en uitvoerende organen, maar waarin deze niet de vrijheid hebben om af te wijken van de sharia, noch om onderling oppositie te voeren (Mawdudi 1980). Bij de verkiezing van leiders is men vooral beducht voor de popularisering van hoge ambten. Zo is wel betoogd dat niet het westerse model van verkiezingen moet worden gevolgd, omdat daar de volksstem tot onaanvaardbare gevolgen kan leiden. Om dezelfde reden is men tegen verkiezingscampagnes. Iemand moet worden verkozen op zijn kwaliteiten en mag zich niet verlagen tot publieke vertoningen van kandidaatstelling. Verschil van mening - in bijvoorbeeld een parlement - is overigens weer wel toegestaan, overeenkomstig de uitspraak van de Profeet: "Verschil van mening onder de kennisdragers in mijn gemeenschap is een teken van Gods genade." Of dit ook inhoudt dat politieke partijen zijn toegestaan, is weer omstreden.

Overigens is het de vraag of dit laatste aspect - het verbod op politieke partijen in een parlement - wel zo typisch islamitisch is. In veel postkoloniale moslimlanden is het meerpartijensysteem afgeschaft omdat dat strijdig met de eenheid van het volk zou zijn. Deze maatregel kwam echter vaak voort uit een socialistisch gedachtegoed. 
Er werd dan een enkele (staats)partij ingesteld of parlementariërs dienden zich op persoonlijke titel verkiesbaar te stellen.

\section{Islamitische democratie}

Het samengaan van islam en democratie is een omstreden onderwerp. De conservatieve ulama én diverse westerse auteurs ontkennen (overigens om verschillende redenen) ten stelligste dat islam en democratie kunnen samengaan. Dat is voor enkele westerse auteurs ook aanleiding om de toenemende islamisering van de moslimwereld aan te merken als een obstakel voor democratisering. ${ }^{3}$ Diverse onderzoeken en cijfers hebben echter aangetoond dat dit causale verband niet zonder meer kan worden gelegd. Zo was de aanduiding 'electorale democratie' in 2002 niet van toepassing op enig Arabisch land, maar wel op veertien niet-Arabische moslimlanden, waaronder Indonesië, Bangladesh en Turkije (respectievelijk de nummers één, twee en vijf op de lijst van grootste moslimlanden). ${ }^{4}$ Weliswaar scoren de moslimlanden met een duidelijk islamitische politiek, zoals Iran, Pakistan, Saoedi-Arabië en Soedan, inderdaad erg slecht op het gebied van vrijheid en democratie, maar dan is de islamitische factor geen verklaring voor de even slechte staat van dienst van uitgesproken seculiere moslimlanden als bijvoorbeeld Irak (onder Saddam Hoessein) of Syrië.

Dat islam en democratie wél goed kunnen samengaan, wordt betoogd door - eveneens - zowel westerse als moslimse auteurs. Onder de westerse auteurs, die vooral een politiek-sociologische benadering hanteren, zijn er die vaststellen dat de wens tot democratie juist een belangrijk element is in de politiek-islamitische bewegingen (Esposito and Voll 1996; Brynen et al. 1995; Diamond et al. 2003). De roep om vrijheid en deelneming aan bestuur, maar ook de roep om eisen aan regeringen als accountability en transparency achten zij typisch voor veel moslimbewegingen. Ook moslimse auteurs schrijven uitvoerig over de 'islamitische democratie'. ${ }^{5}$ Het betreft echter geen bestaand model, maar onderwerp van recent debat. De alternatieve, 'islamitische' vormen van democratie verkeren nog in staat van ontwikkeling. Zo wordt er gerefereerd aan het beginsel van 'consensus' als het gaat om het kiezen van een leider, en 'raadpleging' als het gaat om de relatie tussen leider en volk. Maar hoe men deze begrippen moet invullen en hoe men dient om te gaan met conflictpunten als goddelijke versus seculiere wetgeving, individuele versus communautaire rechten, soevereiniteit van het volk versus die van de religieuze elite, kan men slechts in een enkele islamitische staat zoals Iran in praktijk bezien. Inmiddels is gebleken dat er geen eenduidige vorm is van een islamitisch politiek gedachtengoed, met name als het gaat om democratie, maar dat deze zich - net zoals in het westen - vooral binnen nationale grenzen ontwikkelt (Roy 1994). 


\section{Seculiere democratie, islamitisch beredeneerd}

Nog liberaler zijn degenen die propageren dat, aangezien de sharia niets zegt over staats- en bestuursrecht, het Gods wil is dat de mensen deze lacune zelf invullen. Hier geldt dus een zeer grote mate van vrijheid bij de inrichting van de staat. Deze visie interpreteert de sharia als zeer beperkte rechtsbron, en bovendien op liberale wijze, en past voor het overige siyasa toe (de regelgevende bevoegdheid van de overheid). Deze staatsvorm is wel genoemd "de seculiere staat die de goddelijke wil toestaat" (Ahmed 1987: 150 e.v.).

\subsection{CONCLUSIE}

Historisch gezien is het kalifaat de islamitische staatsvorm bij uitstek. Dit heeft voortgeduurd vanaf het overlijden van de Profeet in 632 tot het in 1924 werd afgeschaft. Niettemin is het opvallend dat men tegenwoordig noch in theorie noch in praktijk het kalifaatmodel als voorbeeld hanteert voor de moderne 'islamitische staat'.

In de moderne theorievorming over de islamitische staat hanteren veel islamistische denkers over het algemeen een fundamentalistische benadering. Dat wil zeggen dat er, los van geschiedenis en tradities, wordt getracht een staatsvorm te reconstrueren op basis van de oorspronkelijke bronnen en de praktijken die dateren uit de vroege islam. Binnen deze theorieën bestaan vervolgens weer conservatieve en liberale interpretaties. Overigens lijkt het vooralsnog vooral bij theorieën te blijven, ofschoon aannemelijk is dat deze theorieën wel hun weerslag hebben op de politieke dynamiek. Alleen van Iran zou men kunnen zeggen dat deze theorieën in praktijk zijn gebracht, waarbij opgemerkt dient te worden dat het hier een shiitische variant van de islamitische staatsgedachte betreft. Saoedi-Arabië is een geval apart, aangezien er niet een islamitisch-staatkundig model is ontwikkeld en toegepast, maar er eerder sprake is van een staat die in 1932 is gesticht op een eigen, zeer traditionele en conservatieve grondslag. 


\section{NOTEN}

1 In Iran en Afghanistan zijn de rivaliserende grootmachten Rusland en Groot-Brittannië enkele malen binnengevallen.

2 Dit zijn de koninkrijken Marokko, Jordanië en Saoedi-Arabië; de emiraten Bahrein, Koeweit, Qatar en de Verenigde Arabische Emiraten; de sultanaten Oman en Brunei.

3 Bijvoorbeeld: "Islam offers (...) worst prospects from political perspective" (Lewis 1993); "Islam prevents the emergence of a civil society" (Gellner 1994); "Islam fosters an essentially illiberal political culture" (Huntington 1996).

4 Freedom House, Freedom in the World. Country Ratings 1972-73 to 2001-2002, Rowmand \& Littlefield Publishers, Inc.

5 Moslimse auteurs worden aangehaald in Esposito and Voll 1996; Brynen et al. 1995; Diamond et al. 2003. Recente publicaties van moslimse auteurs zijn onder meer: Abootalebi 1999; Ahmad 2002; El-Fadl 2003; Filaly-Ansary 1996; Masmoudi 2003; Soroush 2000; Sulaiman 1998; Zafar 1998. 


\section{MODERNE ONTWIKKELINGEN IN HET FAMILIE-, STRAF- EN ECONOMISCHE RECHT}

\subsection{MODERNE ONTWIKKELINGEN IN HET FAMILIE- EN ERFRECHT}

Het familie- en erfrecht behoren tot de weinige rechtsgebieden van de klassieke sharia die in de meeste moslimlanden nog zijn gehandhaafd. Niettemin hebben met name het huwelijks- en echtscheidingsrecht in de loop van de twintigste eeuw enkele ingrijpende ontwikkelingen doorgemaakt, waarvan de twee belangrijkste hier kort worden toegelicht: codificatie en hervorming.

Nagenoeg alle moslimlanden hebben in de loop van de twintigste eeuw hun islamitische familierecht gecodificeerd. Voor het eerst kon men derhalve spreken van islamitische familiewetten. De codificatie betekende ook dat de regelgeving in handen was van de wetgever, en niet meer van de ulama (ofschoon de geestelijke leiders zich wel roerden wanneer de wetgever de sharia naar hun smaak te ruim interpreteerde). De codificatie had voorts tot gevolg dat er voor het eerst sprake was van nationale wetgeving. Gedurende de eerste helft van de twintigste eeuw verkregen de meeste moslimlanden immers hun onafhankelijkheid en werden zij nationale staten, met hun eigen nationale wetten. Ofschoon deze wetten in grote lijnen gemeenschappelijke kenmerken bevatten, weken zij onderling op details af. Men kan dus niet spreken van een enkelvoudig islamitisch familierecht.

De codificeringswerkzaamheden werden tevens aangegrepen om hervormingen door te voeren. Modernisering van het familierecht kan de gemoederen van voor- en tegenstanders enorm bezighouden, zoals de grote aantallen demonstranten in 2002 in Marokko naar aanleiding van hervormingsvoorstellen aantoonden. Modernisering van familierecht betekent vaak ook een concentratie van allerlei machtsconflicten, met name die tussen de seculiere (wetgevende) macht en de ulama, tussen het traditionele patriarchaat en hervormingsgezinde feministen (overigens niet alleen vrouwen), tussen ‘islamitisch'-gezinden en 'westers'-gezinden, enzovoort.

Een belangrijke doelstelling van de wetgever in veel moslimlanden was verbetering van de positie van de vrouw. Haar achterstand was vooral te wijten aan lokale gewoonten, zo werd geredeneerd, en de sharia kon daar verbetering in brengen. Hiertoe bedienden de wetgevers zich op selectieve wijze van het uitgebreide corpus van klassieke sharia-regels en pasten daar bovendien nieuwe interpretatiemethodes op toe. Voorbeelden hiervan zijn de volgende (Coulson 1964; Buskens 1994; Esposito 1982). 


\section{Uitbreiding van de keuze van rechtsscholen}

De wetgevers beperkten zich niet tot één enkele rechtsschool, zoals voorheen de gewoonte was, maar gaven zichzelf het recht een keuze te maken uit de rechtsregels van alle rechtsscholen. Zo treft men in de meeste familiewetten van moslimlanden het (Malikitische) recht van de vrouw op bepaalde gronden te mogen scheiden, het (Hanafitische) recht van de volwassen vrouw te mogen huwen zonder bijstand van een voogd, en het (Hanbalitische) recht om allerlei voorwaarden te stipuleren in het huwelijkscontract.

\section{Neo-ijtihad}

De wetgevers praktiseerden ijtihad (ook wel neo-ijtihad genoemd - Coulson 1964: 202 e.v.). Enkele voorbeelden hiervan zijn:

- In Tunesië rechtvaardigde een nieuwe lezing van de Koran de afschaffing van polygamie. Zij baseerde zich hiervoor op Koranvers 4:229 dat de 'billijke en gelijke behandeling' van meerdere echtgenotes - wat de voorwaarde is voor polygamie (Koranvers 4:3) - aanmerkt als onmogelijk.

- In Egypte is in 2000 op basis van een nieuwe lezing van de Sunna de regeling inzake de khul-scheiding gewijzigd: indien de man weigert te voldoen aan het verzoek van de vrouw om haar tegen compensatie te verstoten (hetgeen voorheen normaliter betekende dat de scheiding geen doorgang vond), dan spreekt de rechter alsnog de scheiding uit mits er sprake is van een gangbare compensatie.

- In de nieuwe Marokkaanse familiewet van 2004 is de nieuwe (want voor klassieke sharia-begrippen onbekende) scheidingsvorm shiqaq ingevoerd, die de vrouw in staat stelt om op grond van 'duurzame ontwrichting' echtscheiding aan te vragen.

- Sommige wetgevers hebben gronden aangevoerd om aan gescheiden vrouwen een eenmalige uitkering toe te kennen die dient als alimentatie. Dit gebeurt vooral in de vorm van een 'schadevergoeding' die wordt berekend op basis van de maandelijkse onderhoudsplicht van de man. De hoogte van deze vergoeding wordt afgemeten naar de schuld die de man wordt aangerekend in de scheiding.

- In Iran bestaat sinds 1992 de mogelijkheid dat de gescheiden vrouw van haar man een bedrag kan vorderen op grond van verrichte werkzaamheden in het huishouden gedurende het huwelijk.

\section{Proces- en administratiefrecht}

De meeste moslimwetgevers durven bepaalde regels niet zonder meer af te schaffen of willen dat niet. Dit geldt voor regels die onveranderlijk zijn omdat zij expliciet in de Koran of Sunna worden vermeld, zoals verstoting en polygamie. In plaats daarvan leggen zij allerlei beperkingen op in de vorm van administratief- en procesrechtelijke voorwaarden en procedures. Zo geldt in veel moslimlanden dat de man zijn verstotingsrecht pas mag uitoefenen nadat de man zijn verstoting heeft ingeschreven en de rechtbank een verzoeningspoging heeft ondernomen (de rechtbank mag overigens aan het verstotingsrecht zelf niet tornen). Ook geldt er vaak voor de man een meldings- 
plicht bij zijn echtgenote in geval van een huwelijk met een tweede vrouw, of moet hij voor de rechtbank eerst kunnen aantonen dat hij in staat is om twee aparte relaties en huishoudens te voeren.

Soms leiden moderne administratiefrechtelijke regelingen tot onoverkomelijke botsingen met de klassieke sharia. Een voorbeeld is de registratie van het huwelijk. Aangezien de meeste moslimlanden hun familierecht baseren op de klassieke sharia, is het niet mogelijk de registratie van het huwelijk als voorwaarde voor de geldigheid ervan te stellen. Huwelijken die overeenkomstig de sharia zijn gesloten, maar niet zijn geregistreerd, kunnen in de meeste moslimlanden daarom niet zonder meer worden aangemerkt als ongeldig of nietig. Zij blijven in beginsel in stand, naast de geregistreerde huwelijken. Een dergelijk gewoonterechtelijk (urfi) of 'sharia'-huwelijk schept veel bewijsrechtelijke problemen.

\section{Verzoening}

Ten slotte nog een korte opmerking over de rechtspraktijk. In veel moslimlanden bestaan aparte familierechtbanken die het sharia-familierecht toepassen. Het procesen bewijsrecht volgt hier de traditionele en sharia-regels. Rechters stellen vaak alles in het werk om partijen te verzoenen. Hiertoe stellen zij vertegenwoordigers uit de families van beide partijen aan om tussen de echtelieden te bemiddelen. In diverse landen is de rechter hier zelfs toe verplicht. ${ }^{1}$ Rechterlijke beslissingen zijn dan eerder tussen- dan eindvonnissen, zodat partijen de gelegenheid wordt gegeven om verder te onderhandelen en zelf tot een oplossing te komen (Rosen 1989; Mir-Hosseini 1993).

\subsection{MODERNE ONTWIKKELINGEN IN HET STRAFRECHT}

Sedert 1972 hebben verscheidene landen islamitisch strafrecht ingevoerd. Het gaat achtereenvolgens om Libië (1972), Pakistan (1979), Iran (1982), Soedan (1983) en deelstaten van Maleisië (Kelatan, 1993²) en Nigeria (twaalf noordelijke staten, 20002001). ${ }^{3}$ Opmerkelijk is dat deze regelgeving op westerse leest is geschoeid. Zij krijgt vorm door middel van wetgeving, en de rechtspraak is in handen van een rechterlijke macht die naar westers model is georganiseerd. Het klassieke islamitische systeem, waarbij de regelgeving was vervat in de complexe casuïstiek van de fiqh en de rechters bij de fuqaha (rechtsgeleerden) te rade gingen voor juridisch advies, is dus niet van toepassing.

(Her)invoering van het islamitische strafrecht betekent niet dat er een compleet nieuw wetboek van islamitisch strafrecht totstandkomt. Het islamitisch strafrecht behelst immers slechts de strafbaarstelling van een vijftal misdrijven (hudud) en de procesrechtelijke regelingen inzake verwonding en doodslag (jinayat) (zie par. 5.2). Invoering van deze islamitische regels betekent derhalve een aanvulling op het reeds bestaande wetboek van strafrecht. Niettemin zijn in landen als Soedan en Iran de strafmaten die typisch zijn voor het islamitische strafrecht, zoals zweepslagen, ook 
toepasbaar gemaakt op 'gewone' delicten. Voorts zijn de restrictieve interpretaties die in de fiqh worden gegeven aan de hudud, in veel van deze moderne wetten losgelaten: er worden vaak geen hoge eisen gesteld aan de bewijslast, en delictsomschrijvingen worden soms zodaning opgerekt dat allerlei andere misdrijven van het 'gewone' recht er ook onder komen te vallen.

De invoering van islamitisch strafrecht dient een aantal doelen. ${ }^{4}$ De belangrijkste is misschien wel de symboliek. Een regime dat zichzelf nadrukkelijk profileert als islamitisch zal zijn legitimiteit vooral willen ontlenen aan de invoering van de sharia. En de sharia manifesteert zich immers het duidelijkst op de gebieden van het familie- en het strafrecht.

Een ander doel is te laten zien dat het islamitische strafrecht, met name als het wordt toegepast in de vorm van snelrecht, beantwoordt aan de roep onder de bevolking om recht en orde, of om afrekening met de aanhang van een vorig regime dat wordt aangemerkt als corrupt.

Omgekeerd dient het islamitische strafrecht in de vorm van snelrecht als een middel voor het regime om de bevolking te onderdrukken. In veel gevallen is invoering van islamitische strafwetgeving het excuus geweest om op grote schaal lijfstraffen in te voeren, ook voor misdaden die niets met het islamitische strafrecht te maken hebben. Lijfstraffen worden beschouwd als een effectief middel van afschrikking, met name als zij publiekelijk ten uitvoer worden gelegd.

Ten slotte dient de invoering van islamitisch strafrecht ook het ideologische doel van een duidelijk anti-westers statement. Islamitisch strafrecht is immers bij uitstek een rechtsgebied van de klassieke sharia dat haaks staat op westerse juridische maatstaven.

\subsection{MODERNE ONTWIKKELINGEN IN HET ECONOMISCHE RECHT}

De economische rechtsregels van bijna alle hedendaagse moslimlanden zijn gebaseerd op westers recht. In enkele moslimlanden heeft echter een re-islamisering van delen van het economische recht plaatsgevonden (Iran, Pakistan en Soedan). In Golfstaten als Saoedi-Arabië heeft daarentegen een omgekeerde ontwikkeling plaatsgevonden: de sharia is van toepassing, maar per koninklijk decreet kan daarvan worden afgeweken om tegemoet te komen aan de eisen van het hedendaagse internationale handelsverkeer. Dit heeft geleid tot een toename van westers-georiënteerde regelgeving op het gebied van handels- en bankrecht (Al-Suwaidi 1994: 26).

De re-islamisering van het economische recht is een exponent van het islamitische activisme. Zij wijt de problemen en misstanden van de moderne moslimmaatschappijen aan de hedendaagse economische systemen (El-Gamal 2003: 7; Kuran 2004: 15). 
Tevens drukt zij een nostalgisch verlangen uit naar de "imaginaire eenvoud, harmonie en welzijn van een oude sociale orde" (Kuran, idem). De islamitische economie wordt door haar voorstanders niet alleen gepresenteerd als een alternatief met voorschriften hoe men op de beste wijze handel dient te drijven, maar tevens als een systeem dat sociale en economische rechtvaardigheid zal brengen.

Vergeleken met het islamitische familie- en strafrecht ligt het islamitische economische recht politiek veel minder gevoelig. Enerzijds is dit het gevolg van het feit dat economie in de klassieke sharia geen nauwomschreven rechtsgebied is, hetgeen ruimte openlaat voor flexibiliteit. Anderzijds liggen economische regels niet politiek gevoelig omdat iedereen, van conservatief tot liberaal, en gelovig of niet, belang heeft bij (economische) welvaart (Saleh 1995: 92). Dit laatste speelde zonder meer een rol in de samenloop van economische liberalisering en islamitisch bankieren in veel moslimlanden - met name in het Midden-Oosten, maar ook Zuidoost-Azië - tijdens de jaren tachtig en negentig van de twintigste eeuw.

De wens van Pakistaanse islamisten als Mawdudi om tot een 'islamitische economie' te komen, heeft sedert de jaren zeventig gestalte gekregen in woord en daad. Veel moslimdenkers hebben geschreven over de vormgeving ervan en zowel particuliere instanties als overheden hebben er regelgeving voor opgesteld. Deze regelgeving is weliswaar gebaseerd op vroege teksten en regels van Koran, Sunna en fiqh, maar maakt tevens gebruik van concepten en methoden van het moderne economische verkeer. Bovendien is de 'islamitische economie' in de geschiedenis van de islam en de klassieke sharia nimmer een onderwerp van studie geweest, zodat men met recht kan spreken van een totaal nieuwe, moderne discipline (Kuran 2004: 16).

De 'islamitische economie' omvat uiteenlopende juridische terreinen als handels-, contracten-, belasting-, ondernemings- en bankrecht. Bepaalde regels komen echter ook voort uit de religieuze plichtenleer. Zo hebben landen als Pakistan, Maleisië, SaoediArabië en Soedan de religieuze belasting (zakat) (zie par. 6.4) verplicht gesteld. In het navolgende beperken wij ons tot de bespreking van islamitisch bankieren en zakat.

\section{Islamitisch bankieren}

Islamitisch bankieren ontstond in het kielzog van het islamitisch activisme en de rijkdom aan oliedollars in de jaren zeventig. De Organisatie van Islamitische Landen (OIC) gaf de aanzet tot de oprichting van twee intergouvernementele organisaties, de Islamic Development Bank (1975) en de International Association of Islamic Banks (1977), die een belangrijke rol gingen spelen in het stimuleren van islamitisch bankieren en in het opstellen en harmoniseren van regels (Ray 1995: 6-7). Vervolgens was Pakistan in 1979 het eerste land dat overging tot islamisering van de gehele banksector, in 1983 gevolgd door Iran en Soedan. 
De belangrijkste rol voor de toenemende populariteit van islamitisch bankieren werd echter niet gespeeld door staatsbanken of (inter)gouvernementele initiatieven, maar door particuliere financiële instellingen (Ray 1995: 8-9). Door de economische hervormingen en liberalisering in de jaren negentig kregen deze instellingen de ruimte om zich een concurrentiepositie te verwerven ten opzichte van de reguliere en staatsbanken. In landen als Egypte en Pakistan kregen de nieuwe islamitische financiële instellingen een enorme aantrekkingskracht bij het grote publiek, dat vanwege gastarbeiderschap in de Golfstaten beschikte over meer spaargeld dan voorheen, maar tevens een diep wantrouwen koesterde tegen de staatsbanken. De gangbare staatsbanken waren in het algemeen niet consument-vriendelijk, mede omdat zij meer gericht waren op de financiering van grote staatsprojecten. De nieuwe islamitische financiële instellingen waren daarentegen juist gericht op de consument en verschaften spaarregelingen en consumentenkredieten. Dat enkele van deze instellingen zich schuldig hebben gemaakt aan frauduleuze praktijken heeft het publiek niet kunnen afschrikken.

Door het succes van de kleine particuliere instellingen gingen veel staatsbanken er uiteindelijk ook toe over islamitische transacties aan te bieden aan hun klanten. Ook ontstond er een toenemende belangstelling van westerse banken voor deze sector, hetzij om zich te profileren als aantrekkelijke investeerder in moslimlanden, hetzij om een moslimclientèle in eigen land aan te trekken. ${ }^{5}$

Het islamitisch bankieren is hierdoor een groeimarkt. In 1995 hadden de islamitische banken in het Midden-Oosten een marktaandeel van 10 tot 20 procent (Safa 1995: 163). Er waren in dat jaar meer dan 100 islamitische banken in 40 landen actief, met een gezamenlijke belegging van circa 20 miljard dollar (Ray 1995: 5; 174-175). Voor 2001 werd geschat dat deze belegging was opgelopen tot 230 miljard dollar (Warde 2001).

Het islamitisch bankieren is een succes in financieel opzicht, maar maakt ook een bloei door als discipline. Zoals hiervoor reeds is opgemerkt, is hier sprake van een modern fenomeen, dat volop in ontwikkeling is. Er wordt zeer veel over gesproken en geschreven, niet alleen door academici en moslimgeleerden, maar vooral door praktijkjuristen. ${ }^{6}$ Islamitisch bankieren is daarom een uniek terrein waar fiqh en westers recht elkaar overlappen: juristen van gerenommeerde westerse banken buigen zich over fatwas van moslimgeleerden om de implicaties daarvan voor hun financiële praktijk te onderzoeken, en omgekeerd zijn er moslimgeleerden die proberen de fiqh aan te passen aan de eisen van het moderne monetaire verkeer (El-Gamal 2003; Mallat 1996: 286-296).

Ondanks het succes van het islamitisch bankieren zijn er ook kritische geluiden. Deze zijn voornamelijk van principiële aard en komen erop neer dat het islamitisch bankieren in zijn huidige vormen geen radicaal andere wijze van bankieren is dan de westerse. Hiervoor worden verschillende argumenten aangevoerd. 
Het islamitisch bankieren, zo wordt betoogd, staat niet los van zijn economische omgeving, waarin doorgaans de beginselen van het islamitisch contracten- en bankrecht niet worden toegepast. De wetgevingen van de meeste moslimlanden kennen vastgestelde rentes, evenals juridische contracten voor hypotheek en verzekering, en handel in aandelen. Het islamitisch bankieren is derhalve een systeem dat is gemodelleerd op de bestaande conventies van het internationale betalingsverkeer. Het dient zich aan te passen aan de nationale regelgeving die zich in het algemeen richt op bankieren-met-rente (Al-Suwaidi 1994: 147). Een andere criticus voegt daaraan toe dat het islamitisch bankieren geen verandering in het economische verkeer heeft teweeggebracht, zelfs niet in de landen waar het van overheidswege is ingevoerd (Kuran 2004).

Andere critici merken op dat praktijk en theorie van het islamitisch bankieren nogal uiteen kunnen lopen (El-Gamal 2000). De meeste islamitische banken laten zich leiden door pragmatisme en bedienen zich daarom zeer weinig van de voorgeschreven vennootschapscontracten musharaka en mudaraba, aangezien deze te risicovol zijn. In plaats daarvan maken de banken gebruik van andere contractsvormen, die hun veel meer zekerheid bieden en aan cliënten toch vormen van inkomsten garanderen (ElGamal 2003: 8).

In het verlengde van het voorgaande ligt de kritiek dat het islamitisch bankieren zich verschuilt achter juridische formaliteiten die zijn gebaseerd op de klassieke sharia, maar feitelijk niet onderdoet voor het conventionele bankieren (El-Gamal 2003; Ray 1995: 82-3). Deze gelijkenissen worden door sommige auteurs overigens juist bestempeld als positief, omdat de islamitische en westerse vormen van bankieren daardoor beter op elkaar kunnen aansluiten (Dar and Presley 1999).

\section{Zakat}

In de tweede helft van de twintigste eeuw heeft de zakat een hernieuwde aandacht gekregen die ongeëvenaard is in de geschiedenis van de islam (Syzow 2002: 418). Economen en juristen, maar ook overheden hebben op verschillende wijzen getracht het instituut van de zakat nieuw leven in te blazen. Een zekere vorm van idealisme speelt daarbij een rol: de zakat wordt gezien als middel om van staatswege inkomensverschillen te reguleren en armoede en onderontwikkeling te bestrijden. Zakat wordt dan gebruikt als een vorm van interne 'ontwikkelingssamenwerking'.

Zes moslimlanden hebben de zakat bij wet verplicht gesteld: Saoedi-Arabië (1951), Libië (1971), Jemen (1975), enkele federale staten van Maleisië, Pakistan (1980) en Soedan (1984). De goederen waarop de zakat wordt geheven, en de berekening van de zakat, verschillen per land. De opbrengsten zijn overigens zeer laag, wat vooral is toe te schrijven aan het beperkte aantal goederen waarop de zakat betrekking heeft (Kuran 2004: 22). Deze beperking, die gebaseerd is op de fiqh, betekent ook dat niet iedereen wordt belast met zakat. De belastingplichtigen zijn vooral de landbouwers 
(Kuran, idem), terwijl zij juist vanwege hun lage inkomens- en welvaartsniveau vaak degenen zijn die in aanmerking komen voor de financiële steun waar de zakat voor bedoeld is.

Ook de distributie van de zakat-opbrengsten laat te wensen over. De beoogde nivellering van de economische ongelijkheid is uitgebleven in de landen die zakat heffen. In Pakistan heeft een rapport van de overheid uit 1988 het uitblijven van succes geweten aan corruptie en slecht beheer van het zakat-systeem. ${ }^{7}$

Naast deze inning van zakat van overheidswege, is er tevens een trend in de moslimwereld waarin non- of quasi-gouvernementele organisaties zakat innen. Betaling vindt plaats op vrijwillige basis, maar leidt wel vaak tot vrijstellingen in de reguliere belasting. Werkzaamheden van deze organisaties omvatten onder meer het verstrekken van rentevrije leningen, een zakat-regeling waar de fiqh niet in voorziet. 


\section{NOTEN}

1 Het aanstellen van arbiters (ev. hakim) om te bemiddelen in echtelijke conflicten is gebaseerd op de verordening van Koran 4: 35: 'En als jullie onmin tussen beiden vrezen, zendt dan een scheidsrechter van zijn mensen en een scheidsrechter van haar mensen. Als zij beiden het weer goed willen maken, dan zal God hen met elkaar verzoenen. God is wetend en welingelicht'.

2 De wet is nog niet officieel van kracht aangezien zij nog goedkeuring behoeft van de federale overheid.

3 De data verwijzen naar de eerste wetgeving; in Iran, Pakistan en Soedan zijn daarna aanvullende en gewijzigde wetten ingevoerd.

4 Het navolgende is gebaseerd op Peters 2005, met name hoofdstuk 5 .

5 Een voorbeeld van dit laatste: sedert 2002 hebben Engelse banken, op dringend verzoek van de overheid en de Bank of England, financiële transacties ontwikkeld die beantwoorden aan de eisen van de sharia zodat tegemoet gekomen kan worden aan de behoeften van Britse moslims (Zoe Coleman, 'Sharia compliant mortgages', www.bbc.co.uk/religion/religions/islam/features/banking).

6 Er wordt veel geschreven over het moderne islamitisch bankieren, vooral in tijdschriften (bijvoorbeeld International Journal of Islamic Finance Services, of de themanummers van Thunderbird International Business Review, 41 (4-5), 1999 en Middle East Policy Council Journal, 9 (1), 2002), maar nog meer op internet (met name de toonaangevende sites www.islamic-finance.net, www.islamic-banking.com, en www.islamic-finance.com).

7 Permanent Commission on Islamisation of Economy, Pakistan 
KLASSIEKE SHARIA EN VERNIEUWING 


\section{SHARIA EN MENSENRECHTEN}

\subsection{INLEIDING}

De discussie over islam en mensenrechten is bij uitstek het terrein waar verwarring kan ontstaan over de verschillende betekenissen van het begrip sharia. Hebben strijdigheden met de mensenrechten betrekking op de klassieke sharia zoals deze is geformuleerd in de rechtswetenschap en het corpus van de fiqh; of op de sharia zoals deze wordt toegepast in hedendaagse moslimlanden; of op de praktijken in moslimlanden die niets te maken hoeven hebben met sharia of islam? Om met het laatste te beginnen: in veel moslimlanden worden mensenrechten geschonden, maar deze schending heeft niet noodzakelijkerwijs een 'islamitisch' karakter. Praktijken als het opsluiten van mensen zonder vorm van proces, vervolging van politieke dissidenten of toepassing van martelpraktijken worden niet voorgeschreven of toegestaan door de islam, noch wordt dit altijd gedaan in naam van de islam. Zelfs als de overheid de islam nadrukkelijk gebruikt als rechtvaardiging voor dergelijke schendingen van mensenrechten, is een dergelijk misbruik 'de' islam niet aan te rekenen (Bielefeldt 1995: 595; Mayer 1995: xiv-xv).

Dit neemt niet weg dat de Koran, Sunna en fiqh wel degelijk bepaalde regels bevatten die strijdig zijn met de mensenrechten. Deze regels zullen in dit hoofdstuk uitvoerig aan de orde komen. Daarbij moet echter onderscheid worden gemaakt tussen de regels enerzijds en de tenuitvoerlegging daarvan in de praktijk anderzijds. De bronnen van de islam kennen, net als het christendom en jodendom, allerlei regels over slavernij, draconische straffen voor overspelige echtelieden en homoseksuelen, en een ondergeschikte positie van de vrouw. Van belang is echter óf deze regels in de actuele wetgeving en rechtspraktijk tot uiting komen en in praktijk worden gebracht, en zo ja, hóe dat dan gebeurt. Daarbij spelen mogelijke verschillen tussen statelijk recht, sharia en gewoonterecht een rol. Slavernij is bijvoorbeeld volgens de klassieke sharia toegestaan, maar is in alle moslimlanden tegenwoordig formeel afgeschaft. Toch komt zij in sommige landen, zoals Mauretanië en Soedan, nog steeds op grote schaal voor, en vaak niet eens op de door de fiqh voorgeschreven wijze. ${ }^{1}$ Praktijken als bijvoorbeeld vrouwenbesnijdenis (Egypte, Soedan en Somalië - zie hierna, par. 10.2.4.) en eerwraak (Turkije, Midden-Oosten, Pakistan) zijn vaak strijdig met de nationale wetten, maar zijn vaak zó gangbaar dat de overheid ze gedoogt. Volgens de (klassieke) sharia zijn deze praktijken niet toegestaan, maar vaak zijn zij zodanig verweven met het gewoonterecht dat de mensen ze zelf sharia noemen.

De hierna volgende paragrafen gaan in op enkele van de belangrijkste regels en onderwerpen in zowel de klassieke sharia als in de sharia zoals deze tegenwoordig in praktijk wordt gebracht, en die strijdig zijn met de hedendaagse internationale mensenrechten, 
alsmede op de hedendaagse toepassing van deze regels in wetgeving en rechtspraktijk. Ten slotte komt de discussie aan de orde die zich de afgelopen twintig jaar onder moslims en moslimstaten heeft afgespeeld over 'islamitische mensenrechten', als alternatief voor de universele (of 'westerse') mensenrechten.

\subsection{SHARIA EN STRIJDIGHEID MET MENSENRECHTEN}

De spanning tussen sharia en de internationaal aanvaarde mensenrechten doet zich met name voor bij de volgende vrijheden en mensenrechten:

- gelijkheid en non-discriminatie op grond van geslacht;

- gelijkheid en non-discriminatie op grond van religie;

- vrijheid van religie en vrijheid van meningsuiting;

- recht op persoonlijke integriteit.

\subsubsection{GELIJKHEID EN NON-DISCRIMINATIE OP GROND VAN GESLACHT}

\section{Klassieke sharia}

Het onderscheid naar geslacht betreft vooral het bewijsrecht (één mannelijke getuige staat gelijk aan twee vrouwelijke getuigen) en het familie- en erfrecht. Het familierecht maakt een duidelijk onderscheid tussen de rechten en plichten van de man en die van de vrouw. Voorbeelden hiervan zijn de volgende:

- De man is de 'opzichter' of 'hoeder' van de vrouw, zowel in de vorm van gezag van de vader over zijn dochter, als dat van de man over zijn echtgenote.

- Alleen de man is verantwoordelijk voor het onderhouden van zijn echtgenote en hun kinderen.

- De moslimman mag met een niet-moslimse vrouw trouwen; de moslimvrouw mag daarentegen niet met een niet-moslimse man trouwen.

- Alleen de man mag meer (maximaal vier) echtgenotes hebben.

- Alleen de vrouw dient haar echtgenoot te gehoorzamen.

- De man kan zonder opgaaf van redenen van zijn vrouw scheiden (verstoting); de vrouw heeft daarentegen beperkte scheidingsmogelijkheden, waarvoor zij in de klassieke sharia bovendien afhankelijk is van de rechter of van haar echtgenoot. ${ }^{2}$

- De vrouw erft de helft van hetgeen haar mannelijke mede-erfgenaam erft.

\section{Praktijk}

In nagenoeg alle moslimlanden zijn de genoemde voorbeelden terug te vinden in de nationale familiewetgeving. Wel zijn in veel nationale familiewetten aanvullende regels opgenomen om de positie van de vrouw enigszins te versterken. Voorbeelden daarvan zijn dat de man, om zijn recht op verstoting of polygamie te verwezenlijken, eerst allerlei financiële en procedurele voorwaarden moet vervullen, wat ertoe leidt dat de uitoefening van deze rechten niet arbitrair kan plaatsvinden. Uitgangspunt is echter 
altijd dat er een verschil is in de rechtspositie van man en vrouw.

Maar in de meeste moslimlanden is de rechtspositie van de vrouw niet eenduidig. Alleen al op familierechtelijk gebied kan grofweg een driedeling worden aangegeven: (1) de status van de vrouw volgens de klassieke sharia, (2) haar status volgens de wet (die vaak gebaseerd is op, maar niet noodzakelijkerwijs gelijkluidend is aan de klassieke sharia), (3) haar positie volgens de lokale gewoonten, waarbij stad en platteland onderling nogal kunnen afwijken. Daarnaast speelt de maatschappelijke positie een belangrijke rol. Vrouwen uit de bovenlagen van de bevolking zijn zich meer bewust van, en bekend met hun wettelijke rechten, terwijl vrouwen uit de veel bredere onderlagen vaker overeenkomstig het lokale gewoonterecht leven. In het laatste geval komen bijvoorbeeld de praktijken voor van vrouwenbesnijdenis, eerwraak en crime passionel, zaken die zowel in de klassieke sharia als de moderne wet niet geoorloofd zijn.

\subsubsection{GELIJKHEID EN NON-DISCRIMINATIE OP GROND VAN RELIGIE: STATUS VAN NIET-MOSLIMS}

\section{Sharia}

Onderscheid op grond van religie heeft in de klassieke sharia vooral betrekking op de status van niet-moslims onder islamitisch gezag (dat wil zeggen, de niet-moslims die woonachtig zijn in de Dar al-Islam). De status van de niet-moslim verschaft hem vrijheid van religie, maar brengt tevens een beperking van zijn burgerrechten met zich mee.

De klassieke sharia kent christenen, joden en zoroasters een apart statuut toe, dat van beschermde gemeenschap (dhimma) (zie par. 3.6). Dit houdt in dat zij, in ruil voor betaling van een speciale belasting en de erkenning van het islamitische gezag, vrij zijn hun religie te belijden. Als wettige onderdanen onder islamitisch gezag genieten de dhimmis de bescherming van de staat en van de sharia ten aanzien van hun leven en eigendommen (Peters 1998: 13). Op het gebied van religieuze aangelegenheden genieten de erkende niet-moslimse gemeenschappen voorts een zekere mate van bestuurlijke, regelgevende en rechtsprekende autonomie.

Deze status van niet-moslims betekent overigens niet dat zij gelijke rechten genieten als moslims. De klassieke sharia kent hun een eigen juridische persoonlijkheid toe (net zoals vrouwen en slaven elk hun eigen juridische persoonlijkheid hebben), die zich onderscheidt van die van de vrije mannelijke moslim. De juridische persoonlijkheid van de niet-moslim is in de klassieke sharia zeer gedetailleerd uitgewerkt en vertaalt zich in een aparte handelingsbekwaamheid op afzonderlijke rechtsterreinen (staats-, familie-, straf- en procesrecht). Zo hebben niet-moslims geen toegang tot hoge bestuursfuncties, mogen zij en moslims over en weer niet van elkaar erven en zijn zij niet onderworpen aan de hadd-straffen. Zij kunnen ook niet getuigen tegen een moslim. 


\section{Praktijk}

In de loop van de geschiedenis van de islam week de praktijk zowel ten voordele als ten nadele af van de klassieke sharia. Zo bekleedden individuele niet-moslims met enige regelmaat zeer hoge posities in het bestuur van moslimlanden. Anderzijds moesten zij zich als gemeenschap vaak allerlei discriminatoire maatregelen laten welgevallen, zoals het moeten dragen van bepaalde kleding, het verbod paarden te berijden, en beperkingen bij de bouw van kerken. Deze maatregelen, alsmede incidentele voorvallen van vervolging, waren afhankelijk van plaats, tijd en machthebber.

Vanaf de negentiende eeuw werd de ondergeschikte status van de niet-moslims in de meeste moslimlanden opgeheven door de invoering van een staatsburgerschap met gelijke burgerrechten, dat onafhankelijk was van religie. Gedurende de periode van staatsvorming halverwege de twintigste eeuw, waarin het nationalistische en socialistisch-seculiere gedachtegoed dominant was, werd in veel moslimlanden nadrukkelijk afstand genomen van het historische en traditionele onderscheid tussen burgers naar religie, met name omdat dit werd beschouwd als een ondermijning van de nationale eenheid.

Niettemin vindt discriminatie van niet moslims nog steeds plaats: de bepaling in de grondwet van veel moslimlanden dat het staatshoofd moslim moet zijn; de familierechtelijke bepalingen dat een moslimse vrouw niet met een niet-moslim mag trouwen; voorts dat moslims en niet-moslims niet van elkaar kunnen erven. Discriminatie van niet-moslims vindt vervolgens nog steeds plaats in de sociale en publieke sfeer, ofschoon vaak incidenteel, en slechts in enkele gevallen van staatswege, zoals in Saoedi-Arabië, Iran en Pakistan.

Saoedi-Arabië is het enige moslimland waar iedere vorm van godsdienstbeoefening anders dan de islam is verboden, met als reden dat dit het hartland is van de islam. In Iran genieten christenen en joden relatieve vrijheid, maar na de Islamitische Revolutie van 1979 zijn veel aanhangers van de Bahai vervolgd, gemarteld en geëxecuteerd, en hun heiligdommen en bezittingen vernield ${ }^{3}$ (de formele beschuldigingen verwezen nauwelijks naar religie, maar vooral naar misdaden en misdrijven tegen de staatsveiligheid, zie ook Mayer 1995).

In Pakistan zijn er tot driemaal toe (1953, 1974 en 1983) processen gevoerd waarin de kwestie aan de orde werd gesteld of de Ahmadiyas zichzelf moslim mochten noemen, hetgeen bijvoorbeeld een voorwaarde was voor het bekleden van bepaalde hoge overheidsposities. De uitslag was steeds ontkennend en in 1984 werd het Ahmadiyas bij wet verboden om, onder andere, zichzelf moslim te noemen, hun gebedshuis moskee te noemen, of de islamitische gebedsoproep te gebruiken.

Overigens gelden in diverse moslimlanden (Egypte, Iran en Pakistan) ook vormen van positieve discriminatie doordat voor religieuze en vaak ook etnische minderheden een vast aantal zetels in het parlement is gereserveerd. 


\subsubsection{VRIJHEID VAN RELIGIE EN VRIJHEID VAN MENINGSUITING (OP HET GEBIED VAN RELIGIE)}

\section{Klassieke sharia}

De klassieke sharia huldigt het beginsel dat het individu het recht heeft zijn religie vrijelijk te beoefenen, zonder dwang (Kamali 1997: 87). Gedwongen bekeringen zijn vanuit de optiek van de sharia derhalve ongeldig. Deze vrijheid van religie wordt echter verschillend uitgelegd voor moslims en niet-moslims. Zo mogen niet-moslims van religie veranderen en moslim worden, maar moslims is het niet toegestaan hun geloof te verzaken. Voorts is de vrijheid van religie voor niet-moslims nagenoeg absoluut: de islam of de moslimheerser zal zich niet mengen in de uitleg van de orthodoxie of de praxis van de niet-moslimse religie. De keerzijde daarvan is dat afwijkingen van die orthodoxie, en kwesties als afvalligheid, verkettering en excommunicatie, worden beschouwd als interne aangelegenheden van die gemeenschap, waarvoor een individueel lid van deze gemeenschap geen beroep kan doen op de centrale (moslim-) overheid. In het geval van de moslim daarentegen is zijn vrijheid van religie beperkt tot de orthodoxie van de islam. Afwijkingen van die orthodoxie, door uitlatingen of gedragingen, kunnen de betrokkene worden aangerekend als afvalligheid. Het gaat dan om uitingsvormen van ketterij, ongeloof of godslastering (Kamali 1997: 213 e.v.). Afvalligheid van de islam wordt door de klassieke sharia bestraft met de doodstraf (zie hoofdstuk 5).

\section{Praktijk}

De doodstraf op afvalligheid van de islam is tegenwoordig in een beperkt aantal moslimlanden wettelijk vastgelegd, te weten Iran, Saoedi-Arabië, Soedan, Mauretanië, Jemen en Qatar. Alleen van de eerste drie landen is bekend dat deze straf ook daadwerkelijk wordt voltrokken.

In de noordelijke deelstaten van Nigeria, waar in 2000 islamitische strafwetgeving is ingevoerd, is afvalligheid niet vermeld in de wetten, maar enkele deelstaten hebben wel de bepaling opgenomen dat "Any act or omission which is not specifically mentioned in this Sharia Penal Code but is otherwise declared to be an offence under the Quran, Soennah and Ijtihad of the Maliki School of Islamic thought shall be an offence under this code".

In Pakistan is afvalligheid niet strafbaar gesteld, maar wel belastering van de Profeet (doodstraf - wet van 1986) en bevuilen, beschadigen of anderszins ontheiligen van de Koran (levenslange gevangenisstraf - wet van 1982). Men zou kunnen betogen dat belastering van de Profeet of ontheiliging van de Koran feitelijk neerkomt op afvalligheid, aangezien afvalligheid niet alleen wordt afgemeten aan de uitdrukkelijke verklaring daartoe van de afvallige moslim, maar ook aan diens handelingen welke zouden wijzen op een afwijzing van islamitische beginselen (Kamali 1997: 213 e.v.). 
In de overige moslimlanden heeft afvalligheid van de islam meestal (juridische) consequenties in de familierechtelijke sfeer: de afvallige wordt een non-persoon, iemand die een 'civiele dood sterft', en wiens huwelijks- en erfrechtelijke rechten komen te vervallen (Berger 2003; Mayer 1995: 141). In gevallen van afvalligheid van moslims vanwege hun bekering tot een andere religie is vaak onduidelijk of de bekering plaatsvindt op religieuze gronden (hetgeen een zeldzaam verschijnsel is in de meeste moslimlanden - Mayer 1995: 142), of van een bekering omwille van de juridische consequenties die de bekering met zich meebrengt, zoals uitsluiting van erfgenamen of ontbinding van een huwelijk (zie voor voorbeelden van Egypte: Berger 2003).

Een nieuwe ontwikkeling sedert de jaren negentig is de beschuldiging van afvalligheid op basis van onislamitisch gedrag. In feite is er dan sprake van een beschuldiging van islamlastering (van godslastering is nooit sprake). Een dergelijke beschuldiging (takfir, letterlijk 'het tot kafir [ongelovige] bestempelen') betekent dat de beschuldigde op grond van zijn uitlatingen, geschriften of gedragingen wordt bestempeld tot een ongelovige en dus in feite een afvallige moslim is. Deze tendens richt zich vooral tegen journalisten, schrijvers en filmmakers. De beschuldiging wordt vaak ingesteld door particulieren in de vorm van een civiele rechtszaak die is bedoeld om personen in diskrediet te brengen, onder meer door het laten verbieden van hun boeken of films. ${ }^{4}$

\subsubsection{RECHT OP PERSOONLIJKE INTEGRITEIT}

\section{Klassieke sharia}

De klassieke sharia kent bepaalde lijfstraffen voor de zogeheten hadd-misdrijven. De straffen zijn onder meer de doodstraf (door zwaard, kruisiging of steniging), amputatie van handen en voeten, en zweepslagen (zie hoofdstuk 5).

\section{Praktijk}

De hadd-misdrijven en -straffen alsmede de vergeldingsregels in geval van doodslag en verwonding (jinayat) zijn in een aantal landen van toepassing. In landen als Saoedi-Arabië en Jemen is deze praktijk een voortzetting van een eeuwenoude strafrechtelijke traditie. In vijf landen zijn de hadd-misdrijven recentelijk weer ingevoerd: Libië, Iran, Pakistan, Soedan, en Noord-Nigeria. Alleen in Libië is, met de uitzondering van een keer in 2003, nimmer overgegaan tot voltrekking van een hadd-straf. In Pakistan is alleen (maar wel regelmatig) geseling als straf opgelegd en voltrokken. In deze vijf landen, met uitzondering van Libië, is ook de jinayat bij wet ingevoerd. De vergeldingsstraffen (doodstraf en verminking) zijn alleen in Pakistan niet ten uitvoer gelegd.

In enkele moslimlanden schrijft men ten onrechte bepaalde praktijken die een inbreuk vormen op de persoonlijke integriteit van personen toe aan de islam. Een bekend voorbeeld is de vrouwenbesnijdenis, ook aangeduid als female genital mutilation (FGM), 
die verschillende gradaties van verminking van het vrouwelijke geslachtsorgaan kent. Zij wordt voornamelijk gepraktiseerd in aan de Nijl gelegen landen: Egypte, Soedan en Somalië. Deze traditie dateert uit faraonische tijden (Berkey 1996), maar is ook heden ten dage nog zeer wijdverbreid: volgens schattingen is in Egypte ongeveer 97 procent van de vrouwen besneden, zowel onder moslims als bij christenen en animisten. ${ }^{5}$ Ofschoon overheden en religieuze autoriteiten zich tegen vrouwenbesnijdenis verzetten, wordt deze praktijk niettemin in de volksmond vaak als 'islamitisch' gesanctioneerd. ${ }^{6}$

\section{3 'ISLAMITISCHE' MENSENRECHTEN}

\subsubsection{INTERNATIONALE 'ISLAMITISCHE' DOCUMENTEN EN VERDRAGEN}

Op internationaal niveau blijken moslimlanden graag een 'eigen' (islamitisch) alternatief te willen bieden op het gebied van mensenrechtenverdragen. De punten die hiervóór zijn besproken blijken echter enorme hindernissen te vormen bij het formuleren van mensenrechten die voldoen aan internationale normen. Enerzijds is er sprake van een behoefte aan gelijkschakeling met de internationale regels, maar anderzijds wil men vasthouden aan de 'islamitische' normen. De compromissen resulteren vaak in ambivalente formuleringen die niet bijdragen aan de duidelijkheid en geloofwaardigheid van de documenten.

Totnogtoe zijn op interstatelijk niveau twee internationale documenten opgesteld: de Universele Islamitische Verklaring van de Mensenrechten (1981) (UIDHR) en de Cairo Verklaring van Mensenrechten in de Islam (1990). Een uitvoerig en vergelijkend onderzoek naar deze verklaringen is verricht door Mayer (1995). Mayers oordeel over de Universele Verklaring van 1981 is negatief: niet alleen wijken de Engelse en (originele) Arabische tekstversies van elkaar af, maar ook zijn veel bepalingen onduidelijk, ambivalent en onderling tegenstrijdig: "Although the UIDHR is generally representative of conservative Muslim opinion, the inconsistencies and equivocation in the UIDHR suggest that its authors may not have been able to achieve a consensus among themselves about how Islamic human rights norms should be formulated” (Mayer 1995: 22).

De Cairo Verklaring lijkt meer een eensluidend standpunt van de betrokken moslimlanden te vertegenwoordigen, met name toen zij in 1990 door de 51 ministers van Buitenlandse Zaken van de Organisatie van de Islamitische Conferentie (OIC) werd aangenomen. Ondanks deze consensus over de interpretatie van islamitische mensenrechten bleken de afzonderlijke lidstaten van de oIc in de daaropvolgende jaren echter weer net zo verschillende standpunten over dit onderwerp in te nemen als daarvoor (Mayer 1995: 24). Net als haar voorganger, de Universele Islamitische Verklaring van 1981, vertegenwoordigt de Cairo Verklaring de conservatieve islamitische visie en opnieuw zijn de bepalingen niet eenduidig. Zo worden man en vrouw gelijkgesteld in 
'menselijke waardigheid', maar gelden voor ieder van hen afzonderlijke 'rechten' (artikelen 1 en 6). Ook de andere klassieke mensenrechten, zoals vrijheid van religie (inclusief het aannemen van een andere religie) en de positie van religieuze minderheden, worden niet, of niet eensluidend, gewaarborgd in de Cairo Verklaring (Mayer 1995: 138, 159-160).

\subsubsection{KERNPUNTEN VAN 'ISLAMITISCHE' MENSENRECHTEN}

Het debat onder moslims over de formulering van 'islamitische mensenrechten' is van recente datum. Posities in dit debat lopen uiteen van de verwerping van het concept mensenrechten als een westerse en postkoloniale uitvinding, tot een naarstig herformuleren van de klassieke sharia teneinde het moderne concept van de mensenrechten daarin in te passen. Het discours onder moslims betreffende islamitische mensenrechten is vaker een reactie op westerse concepten van mensenrechten en westerse beschuldigingen van mensenrechtenschendingen dan een wezenlijk inhoudelijke discussie voortkomend uit de noden en vragen in de betrokken landen zelf (Halliday 1995: 155; Mayer 1995: 47-48, 177).

Niet alleen de motivatie voor het formuleren van 'islamitische' mensenrechten roept vraagtekens op, maar ook de inhoud van deze mensenrechten. Immers, net als andere religies kent de islam het concept mensenrechten niet. Voorstanders van islamitische mensenrechten zijn derhalve vooral bezig met de vraag hoe dit hedendaagse concept kan worden voorzien van een islamitische grondslag. De liberalen onder hen trachten nieuwe methoden van rechtsvinding te ontwikkelen om islamitische regels zodanig te kunnen interpreteren dat zij in overeenstemming zijn met de universele mensenrechten. Hiertoe worden algemene islamitische beginselen als gelijkheid, gemeenschapszin en rechtvaardigheid aangehaald (Khadduri 1984: 236-237). De meerderheid van de pleitbezorgers van islamitische mensenrechten leggen zich echter neer bij de beperkingen die inherent zijn aan het islamitische theologisch-juridische gedachtegoed. Dit heeft tot resultaat dat hun mensenrechtenverklaringen zeer ruim zijn opgezet - waarschijnlijk met het doel om zowel universele als islamitische fundamentele rechten te ondervangen (Halliday 1995; Mayer 1995; Sardar Ali 2000). Onderwerpen die vanwege hun typisch 'islamitische' karakter weinig manoeuvreerruimte bieden voor de pleitbezorgers van islamitische mensenrechten zijn: de Koranische regels, de positie van het individu, het gelijkheidsbeginsel, de vrijheid van religie, en de vrijheid van meningsuiting wanneer deze betrekking heeft op religie. Deze zullen hier afzonderlijk worden besproken.

\section{Koranische regels}

De islamitische dogmatiek beschouwt de regels die expliciet staan vermeld in de Koran en de Sunna als onveranderlijk en onvervreemdbaar (zie ook hoofdstuk 2). Deze regels, die gering in aantal zijn, hebben vooral betrekking op de familierechtelijke 
positie van de vrouw en de hadd-misdrijven. Dat zijn echter uitgerekend de regels die in veel gevallen strijdig zijn met de fundamentele mensenrechten die zijn geformuleerd in de internationale verdragen. Enkele liberale moslimauteurs - die overigens geen meerderheid vormen in het hedendaagse denken over de sharia - hebben betoogd dat er binnen het raamwerk van de klassieke sharia niettemin mogelijkheden zijn om deze regels te verzoenen met de fundamentele mensenrechten (An-Naim 1990; Mernissi 1992; Sardar Ali 2000).

\section{Relatie tussen individu en staat}

Een van de kenmerken van mensenrechten is dat het rechten betreft van het individu jegens de staat: hetzij in de zin dat het individu niet door de staat in zijn rechten aangetast mag worden (klassieke rechten), hetzij in die zin dat het individu jegens de staat aanspraak kan maken op bepaalde rechten (sociale rechten). Onder de ulama is deze relatie omstreden. Weliswaar bevestigen zij de individualiteit van de moslim (Khadduri 1984: 233), maar tegelijkertijd maakt de individuele gelovige toch vooral deel uit van de gemeenschap der gelovigen. De nadruk ligt dan ook meer op plichten jegens de gemeenschap en God dan op rechten van het individu zelf (Artz 1990: 206; Dalacoura 1998: 44). Zo wordt er altijd gesproken over de verplichting van de man zijn echtgenote te onderhouden, en nimmer over het recht van de vrouw op onderhoud door haar man, terwijl zij dat recht zonder meer kan opeisen. Rechten worden gewaarborgd door een netwerk van sociale plichten (Rosen 1989: 74). Het is dus vooral een kwestie van een principieel accentverschil: niet het recht van het individu, maar de plicht jegens de gemeenschap staat centraal. Veel moderne auteurs menen daarom dat de islam een sterk anti-individualistische inslag heeft (Artz 1990; Tibi 1990; Arkoun 1994; Mayer 1994; An-Naim 1990).

Deze opvatting heeft ook gevolgen voor de formulering van de relatie tussen individu en staat. De klassieke sharia gaat uit van de ideale situatie dat er geen conflict bestaat tussen de belangen en de rechten van de staat enerzijds en die van zijn burgers anderzijds, omdat het handhaven van de sharia door de staat automatisch de bescherming van het individu inhoudt (Coulson 1957: 58-59; Kamali 1997: 18). Daarom heeft de sharia nooit een mechanisme ontwikkeld dat de individuele rechten beschermt tegen de overheid. Overigens dient opgemerkt te worden dat het laten prevaleren van sociale plichten en rechten van de gemeenschap boven die van de burgers niet is voorbehouden aan de islam. Veel niet-westerse landen noemen het gebrek aan aandacht voor deze gemeenschapsrechten als tekortkoming van het westerse mensenrechtenmodel.

\section{Gelijkheid en non-discriminatie}

De verdedigers van 'islamitische' mensenrechten nemen in het algemeen het standpunt in dat discriminatoire regels ten aanzien van vrouwen en niet-moslims niet noodzakelijkerwijs een inbreuk vormen op het gelijkheidsbeginsel (Mayer 1995: 80). Deze stellingname is te vergelijken met die van (blanke) mannen in het negentiende-eeuwse 
westen bij wie gelijkheid hoog in het vaandel stond, maar die het vanzelfsprekend achtten dat deze gelijkheid zich niet uitstrekte tot vrouwen en kleurlingen (Mayer, idem). Dit uitgangspunt wordt vanuit islamitische optiek gerechtvaardigd door de nadruk te leggen op het complementaire karakter van de rechten van verschillende personen.

Vanwege deze opvatting worden in de islamitische-mensenrechtendebatten verschillende interpretaties gegeven aan het gelijkheids- en non-discriminatiebeginsel. Het verbod op discriminatie wordt voornamelijk gebezigd ten aanzien van ras, huidskleur of nationaliteit; het non-discriminatiebeginsel op basis van geslacht en religie wordt niet genoemd. Het beginsel van gelijkheid wordt ten aanzien van geslacht en religie weliswaar als beginsel uitgedragen, maar blijkt vaak te worden genuanceerd. Zo is volgens Egyptische juristen de volledige uitsluiting van de vrouw van een erfenis in strijd met het non-discriminatiebeginsel, maar dit beginsel geldt niet voor de regel dat de erfportie van de vrouw de helft bedraagt van het erfdeel van haar mannelijke mede-erfgenaam (Berger 2002: 586). Een ander voorbeeld van deze, in westerse ogen, ambivalente houding is te vinden in de Cairo Verklaring van Rechten van de Mens die in 1990 door de Organisatie van de Islamitische Conferentie is aangenomen. Daarin wordt melding gemaakt van de gelijkheid van man en vrouw, maar deze heeft slechts betrekking op de 'menselijke waardigheid' en niet nader aangeduide 'basale plichten en rechten' (cursivering auteur):

Artikel 1: (...) All men are equal in terms of basic human dignity and basic obligations and responsibilities, without any discrimination on the grounds of race, colour, language, sex, religious belief, political affiliation, social status or other considerations. (...)

Artikel 6: (a) A woman is equal to man in human dignity, and has rights to enjoy as well as duties to perform; she has her own civil entity and financial independence, and the right to retain her name and lineage.

(b) The husband is responsible for the support and welfare of the family.

\section{Vrijheid van religie}

Ten aanzien van vrijheid van religie richt het discours over islamitische mensenrechten zich op de religie als georganiseerd geloof, niet als persoonlijke invulling van dat geloof. Dit geldt voor moslims en niet-moslims. Aan niet-moslims garandeert de sharia de vrijheid om hun religie ongehinderd te kunnen belijden als onderdeel van de 'bescherming' (dhimma) die zij onder de islam genieten. Deze vrijheid komt echter niet toe aan de individuele niet-moslim, maar aan de geloofsgemeenschap waartoe hij of zij behoort. Als de rooms-katholieke of koptische gemeenschap bepaalde uitspraken van haar gelovigen niet tolereert of bepaalde familierechtelijke regels stelt die individuele gelovigen onwelgevallig zijn, dan acht de sharia dat een interne aangelegenheid. De individuele niet-moslim heeft ook geen mogelijkheid om zijn recht te halen bij de centrale overheid. 
Hetzelfde geldt voor moslims, met dien verstande dat hun geloof tevens de religie van de staat is, en de staat volgens de sharia verplicht is de regels van de islam te handhaven. De moslim heeft een zekere vrijheid in de persoonlijke beleving van zijn islamitisch geloof, maar de grenzen van deze vrijheid worden bepaald door het geloof zelf. Het verbod van afvalligheid is absoluut: het wordt in het islamitische-mensenrechtendiscours niet beschouwd als een inbreuk op de (persoonlijke) vrijheid van religie, maar juist als de vrijheid van de religie zelf om die regel te mogen handhaven. Als gelovige telt men niet als individu, maar als lid van een geloofsgemeenschap, en is men als zodanig onderworpen aan de regels van die gemeenschap.

De strakke lijnen die door de sharia langs de grenzen van de religies van de geloofsgemeenschappen worden getrokken hebben ook gevolgen voor de vrijheid van meningsuiting met betrekking tot religie. Tot de islamitische mensenrechten behoort het respecteren van elkanders religie, zodat het afdwingen van bekeringen dan wel het beledigen van elkanders religie wordt beschouwd als strijdig met die rechten. 


\section{NOTEN}

1 'Mauretania: A future free from slavery' (Amnesty International Report 2001 en Amnesty International, 7 november 2002). 'Slavery and Slave Redemption in the Sudan', Human Rights Watch backgrounder, 2002.

2 Het betreft dan de echtscheiding die de vrouw op een beperkt aantal gronden kan aanvragen bij de rechter, en de mogelijkheid voor de vrouw om haar echtgenoot te verzoeken gebruik te maken van zijn recht tot verstoting (zie par. 4.2).

3 Economic and Social Council Commission on Human Rights, Report on the Human Rights Situation in the Islamic Republic of Iran by the Special Representative of the Commission, $\mathrm{E} / \mathrm{CN} \cdot 4 / 1987 / 23$.

4 Geruchtmakende rechtszaken waarin het tot civielrechtelijke veroordelingen kwam, speelden zich af in Egypte tegen de filmregisseur Youssef Chahine (1995) en universiteitsdocent Nasr Abu Zayd (1996), en in Koeweit tegen de schrijfsters Layla Uthmaan en Alya Shuaib (1999) en de universiteitsdocent Ahmed Al-Baghdadi (1998).

5 Egyptian Demographic Health Survey, 1996.

6 In Egypte heeft de hoogste islamitische autoriteit, de sjeik van Al-Azhar, in de jaren tachtig en negentig verklaard dat vrouwenbesnijdenis wel degelijk islamitisch is. Zijn opvolger, sjeik Tantawi, heeft hier in 1996 afstand van genomen, en samen met de Koptische Paus herhaaldelijk campagne gevoerd tegen deze praktijk. Ook het Administratief Hooggerechtshof verklaarde in 1997 vrouwenbesnijdenis strijdig met de sharia (Bälz 1998). 


\section{LITERATUUR}

Abootalebi, A.R. (1999) 'Islam, Islamists and democracy', Middle East Review of International Affairs, vol. 3, nr. 1.

Abu Sahlieh, S.A.A. (1979) L’impact de la religion sur l'ordre juridique, Cas de l'Egypte, Non-Musulmans en pays d'Islam, Fribourg.

Ahmad, M. (2002) 'Islam and democracy. The emerging consensus', IslamOnline, (www.islamonline.net/english/Contemporary/2002/article15.shtml).

Ahmed, I. (1987) The concept of an Islamic state. An analysis of the ideological controversy in Pakistan, London: Frances Pinter.

Al-'Ashmawi, M.S. (1998) 'The codification of Islamic law’, in Ch. Kurzman (ed.) Liberal Islam. A sourcebook, Oxford: Oxford University Press.

Al-Suwaidi, A. (1994) Finance of international trade in the Gulf, London: Graham \& Trotman.

An-Naim, A. (1990) Towards an Islamic reformation: Civil liberties, human rights and international law, Syracuse: Syracuse University Press.

Ansari-Pour, M.A. (1995) 'Prohibition of interest under Iranian legal system since the revolution', in H.R. Ruttly and C. Mallat (eds.), Commercial law in the Middle East, London: Graham \& Trotman.

Antoun, R.T. (1989) Muslim preacher in the modern world. A Jordanian case study in comparative perspective, Princeton: Princeton University Press.

Arkoun, M. (1994) Rethinking Islam. Common questions, uncommon answers, Boulder: Westview Press.

Artz, D.E. (1990) ‘The application of international human rights in Islamic states', Human Rights Quarterly, vol. 12, nr. 2.

Asad, T. (2001) Thinking about secularism and law in Egypt, Leiden: IsIM Papers.

Ayubi, N. (1991) Political Islam. Religion and politics in the Arab world, London: Routledge.

Badr, G.M. (1978) 'Islamic law: its relation to other legal systems', The American Journal of Comparative Law, vol. 26.

Baer, G. (1997) 'The waqf as a prop for the social system', Islamic Law and Society,vol. 4 , nr. 3 .

Bahaa-Eldin, Z. (1999) 'Formal and informal finance in Egypt: The significance for legal pluralism', in B. Dupret, M. Berger and L. Alzwaini (eds.) Legal pluralism in the Arab world, Kluwer Law International.

Bälz, K. (1996) 'Sharia and qanun in Egyptian law: A systems theory approach to legal pluralism', Yearbook of Islamic and Middle Eastern Law, vol. 2.

Bälz, K. (1998a) 'La réconstruction séculière du droit islamique: la Haute Cour constitutionnelle égyptienne et la bataille du voile dans les écoles publiques', Droit et Société, nr. 39.

Bälz, K. (1998b) 'Human rights, the rule of law, and the construction of tradition. The Egyptian Supreme Administrative Court and female circumcision', Egypte Monde Arabe. 
Barbar, K. and G. Kepel (1982) Les waqs dans L'Egypte contemporaine, Cairo: Centre d'Etudes et Documentation Economiques Juridiques et Sociales.

Barnes, J.R. (1986) An introduction to religious foundations in the Ottoman empire, Leiden: E.J. Brill.

Ben Nefissa, S. (1999) 'The haqq al-'Arab: Conflict resolution and distinctive features of legal pluralism in contemporary Egypt', in B. Dupret, M. Berger and L. Alzwaini (eds.) Legal pluralism in the Arab world, Kluwer Law International.

Behrens-Abou Seif, D. (1994) Egypt's adjustment to Ottoman rule: Institutions, waqf \& architecture in Cairo (16th \& 17th centuries), Leiden: E.J. Brill.

Berger, M. (1999a) 'The sharia and legal pluralism: The example of Syria', in B. Dupret, M. Berger and L. Alzwaini (eds.) Legal pluralism in the Arab world, Kluwer Law International.

Berger, M. (1999b) 'Three recent views on the implementation of Islamic law in Egypt', Droits d'Egypt: Histoire et sociologie, Egypt Monde Arabe, nr. 44, Cairo: Centre d'Etudes et de Documentation Economique et Juridique.

Berger, M. (2001) 'Public policy and Islamic law: The modern dhimmi in contemporary Egyptian family law’, Islamic Law \& Society, vol. 8, nr. 1.

Berger, M. (2002a) 'Conflicts law and public policy in Egyptian family law: Islamic law through the back door', The American Journal of Comparative Law, vol. 5o, nr. 3.

Berger, M. (2002b) 'De ordening der wettelijke beginselen: De rechten en plichten van het huwelijk' (vertaald uit al-Kasani), in A. Vrolijk (red.), Taal der engelen, Amsterdam: Uitgeverij Contact.

Berger, M. (2003) 'Apostasy and public policy in Egypt: An evaluation of recent cases of Egypt's highest courts', Human Rights Quarterly, vol. 25, No. 3.

Berger, M. (2005) 'Sharia and Public Policy in Egyptian Family Law, Groningen: Hephaestos Press.

Berkey, J.P. (1996) 'Circumcision circumscribed: Female exision and cultural accomodation in the medieval near east', International Journal of Middle East Studies, nr. 28.

Bielefeldt, H. (1995) 'Muslim voices in the human debate', Human Rights Quarterly, No. 17. Botiveau, B. (1990) 'Droit islamique: Du politique à l'anthropologique', Droit et Societé, No. 15 .

Botiveau, B. (1993) Loi islamique et droit dans les sociétés arabes, Paris: Karthala.

Brown, N.J. (1997) 'Sharia and the state in the modern Middle East', International Journal of Middle East Studies, vol. 29.

Brynen, R., B. Korany and P. Noble (eds.) (1995) Political liberalization \& democratization in the Arab world, Boulder: Lynne Rienner.

Buskens, L.P.H.M. (1999) Islamitisch recht en familiebetrekkingen in Marokko, Amsterdam: Bulaaq.

Cahen (2002) 'Dhimma', Encyclopaedia of Islam, Leiden: E.J. Brill.

Charfi, M. (1987) 'L'influence de la religion dans le droit international privé des pays musulmans,' Receuil des Cours de l'Academie de Droit International de La Haye, vol. 203, No. 3 . 
Chehata, C. (1965), 'Etudes de philosophie musulmane du droit', Studia Islamica, nr. 23.

Coulson, N. (1957) 'The individual and the state in Islamic law', The International and Comparative Law Quarterly, vol. 6.

Coulson, N. (1964) A history of Islamic law, Edinburgh: Edinburgh University Press.

Coulson, N. (1969) Conflicts and tensions in Islamic jurisprudence, Chicago: The University of Chicago Press.

Coulson, N. (1971) Succession in the Muslim family, Cambridge: Cambridge University Press.

Crecelius, D. (1997) 'Egyptian ulama and Modernization', Scholars.

Crone, P. (2004) God's rule. Government and Islam, New York: Columbia University Press.

Dalacoura, K. (1998) Islam, liberalism and human rights, London: I.B.Tauris.

Dar, H.A. and J.R. Presley (1999) 'Islamic finance: A western perspective', Islamic Journal of Islamic Financial Services, vol. 1, No. 1.

Deguilhem, R. (ed.) (1995) Waqf dans l'espace islamique: Outil de pouvoir sociopolitique, Damascus: Institut Français d'Etudes Arabes de Damas.

Diamond, L., M.F. Plattner and D. Brumberg (2003) Islam and democracy in the Middle East, John Hopkins University Press.

Dupret, B. (1996) 'La Sharia comme référent législatif. Du droit positif à l'anthropologie du droit', Egypte-Monde Arabe, No. 25.

Dupret, B. (1999) 'Legal pluralism, normative plurality, and the Arab world', in B. Dupret, M. Berger and L. Alzwaini (eds.) Legal pluralism in the Arab world, Kluwer Law International.

El Alami, D.S. and D. Hinchcliffe (1996) Islamic marriage and divorce laws of the Arab world, London: Kluwer Law International.

El-Gamal, M. (2000) 'The economics of 21st century Islamic jurisprudence' (voordracht op Fourth Harvard University Forum on International Finance).

El-Gamal, M. (2003) '”Interest” and the paradox of contemporary Islamic law and finance', Fordham International Law Journal, December.

Esposito, J.L. (1982) Women in Muslim family law, Syracuse: Syracuse University Press.

Esposito, J. and J. Voll (1996) Islam and democracy, Oxford: Oxford University Press

Esposito, J. and J. Voll (1998) Islam and politics, Syracuse: Syracuse University Press.

Fattal, A. (1958) Le statut légal des non-musulmans en pays d’islam, Beirut: Imprimerie Catholique.

Filali-Ansary, A. (1996) 'Islam and liberal democracy: The challenge of secularization', Journal of Democracy, vol. 7, nr. 2.

Fyzee, A.A.A. (1974) Outlines of muhammadan law, Oxford: Oxford University Press (4th edition).

Gaffney, P.D. (1994) The prophet's pulpit. Islamic preaching in contemporary Egypt, Berkeley and Los Angeles: University of California Press. 
Gellner, E. (1994) 'Islam prevents the emergence of a civil society', Conditions of liberty: Civil society and its rivals, London: Hamish Hamilton.

Gervers, M. and R.J. Bikhazi (eds.) (1990) Indigenous christian communities in Islamic lands (eight to eighteenth centuries), Toronto: Pontifical Institute of Mediaeval Studies.

Haeri, S. (1989) Law of desire. Temporary marriage in Iran, London: I.B. Tauris. Hallaq, W. (1984) ‘Was the gate of ijtihad closed?', International Journal of Middle East Studies, vol. 16.

Hallaq, W. (1994) 'From fatwas to furu: Growth and change in Islamic substantive law', Islamic Law and Society, vol. 2.

Hallaq, W. (1997) A history of Islamic legal theories, Cambridge: Cambridge University Press.

Halliday, F. (1995) 'Relativism and universalims in human rights: The case of the Islamic Middle East', Political Studies, nr. 43.

Hill, E. (1978) 'Comparative and historical study of modern and Middle Eastern law', The American Journal of Comparative Law, vol. 26.

Hodgson, M.G.S. (1977) The venture of Islam. vol. 3: The gunpower empires and modern times, Chicago: Chicago University Press.

Huntington, S. (1996) The clash of civilizations and the remaking of the world order, New York: Simon and Schuster.

Kamali, M.H. (1991) Principles of Islamic jurisprudence, Cambridge: Islamic Texts Society.

Kamali, M.H. (1997) Freedom of expression in Islam, Cambridge: Islamic Texts Society.

Khadduri, M. (1984) The Islamic conception of justice, Baltimore: John Hopkins University Press.

Khuri, F. (1989) Imams and emirs. State, religion and sects in Islam, London: Saqi Books.

Kuran, Timur (2004) Islam and mammon: The economic predicaments of Islamism, Princeton: Princeton University Press.

Kurzman, Ch. (1998) Liberal Islam, A sourcebook, Oxford: Oxford University Press.

Lambton, A.K.S. (1981) State and government in medieval Islam, Oxford: Oxford University Press.

Lambton, A.K.S. (1990) ‘Khalīfa: In political theory', Encyclopaedia of Islam, Leiden: Brill.

Lapidus, I.M. (1975) 'The separation of state and religion in the development of early Islamic society', International Journal of Middle East Studies, nr. 6.

Lewis, B. (1993) 'Islam and liberal democracy', The Athlantic Monthly, February.

Linant de Bellefonds, Y. (1965) Traité de droit musulman comparé II. Le mariage, la dissolution du marriage, Paris: Mouton.

Madelung, W. (1990) 'Imāma', Encyclopaedia of Islam, Leiden: Brill. 
Makdisi, J. (1985) 'The legal logic of equity in Islamic law', The American Journal of Comparative Law, vol. 33 .

Mallat, C. (1996) 'Tantawi on banking operations', in Kh.M. Masud, B. Messick and D.S. Powers (eds.), Islamic legal interpretation. Muftis and their fatwas, Cambridge: Harvard University Press.

Mallat, Ch. and J. Connors (eds.) (1990) Islamic family law, London: Graham \& Trotman.

Martin, V. (2000) Creating an Islamic state. Khomeini and the making of a new Iran, London: I.B. Tauris.

Masmoudi, R. (2003) 'The silenced majority', Journal of Democracy, vol. 14, nr. 2.

Masud, Kh.M. (2001) Muslim jurists' quest for the normative basis of sharia, Leiden: ISIM Papers.

Masud, Kh.M., B. Messick and D.S. Powers (eds.) (1996) Islamic legal interpretation. Muftis and their fatwas, Cambridge: Harvard University Press.

Maududi, A.A. (1980) The Islamic law and constitution, Lahore: Islamic Publications. Mayer, A.E. (1987) 'Law and religion in the Middle East', The American Journal of Comparative Law, vol. 35 .

Mayer, A.E. (1995) Islam and human rights. Traditions and politics, Boulder: Westview Press.

Mernissi, F. (1992) Islam and democracy, New York: Addison-Wesley.

Milliot, L. (1954) 'La pensée juridique de l'islam', Revue Internationale de Droit Comparé, vol. 6, nr. 3

Milliot, L. et F.-P. Blanc (1987) Introduction à l'étude du droit musulman, Paris: Sirey. Mir-Hosseini, Z. (1993) Marriage on trial. A study of Islamic family law, London: I.B. Tauris.

Nasir, J.J. (1990) The Islamic law of personal status, London: Graham \& Trotman.

Nasir, J.J. (1994) The status of women under Islamic law, London: Graham \& Trotman.

Otto, J.M. (2006) Sharia en nationaal recht. Rechtssystemen in moslimlanden tussen traditie, politiek en rechtsstaat, WRR Verkenning nr. 11, Amsterdam: Amsterdam University Press

Peters, R. (1990) 'Het islamitische strafrecht', Justitiële Verkenningen, vol. 16, nr. 6.

Peters, R. (1994) 'The Islamization of criminal law: A comparative analysis', Die Welt des Islams, vol. 34.

Peters, R. (1998) 'Islamic law and human rights. A contribution to an ongoing debate', Human Rights and Islam, Maastricht: RIMO.

Peters, R. (2005) Crime and punishment in Islamic criminal law, Cambridge: Cambridge University Press (forthcoming).

Rahman, F. (1979) Islam (2nd ed.), Chicago: Chicago University Press.

Rahnema, A. (ed.) (1994) Pioneers of Islamic revival, London: Zed Books.

Ray, N.D. (1995) Arab Islamic banking and the renewal of Islamic law, London: Graham \& Trotman. 
Rosen, L. (1989) The anthropology of justice. Law as culture in Islamic society, Cambridge: Cambridge University Press.

Roy, O. (1994) The failure of political Islam, London: I.B. Tauris.

Roy, O. (2003) De globalisering van de islam, Amsterdam: Van Gennep.

Safa, R. (1995) 'Perspectives on bank failures in the Middle East', in H.R. Ruttly and C. Mallat (eds.) Commercial law in the Middle East, London: Graham \& Trotman.

Saleh, N. (1992) Unlawful gain and legitimate profit in Islamic law, London: Graham \& Trotman

Saleh, N. (1995) 'Company legislation in the Gulf: Recent developments', in H.R. Ruttly and C. Mallat (eds.) Commercial law in the Middle East, London: Graham \& Trotman.

Sardar Ali, S. (2000) Gender and human rights in Islam and international law, The Hague: Kluwer International Law.

Schacht, J. (1964) An introduction to Islamic law, Oxford: Oxford University Press.

Schacht, J. (1986) 'Hadd', Encyclopaedia of Islam, Leiden: Brill.

Sedwick, M. (2003) 'Is there a church in Islam?', ISIM Newsletter, nr. 13.

Siddiqi, M.N. (1983) Issues in Islamic banking, London: The Islamic Foundation.

Siegman, H. (1964) 'The state and the individual in Sunni Islam', The Muslim World, vol. 54 .

Skovgaarden-Petersen, J. (1997) Defining Islam for the Egyptian state: Muftis and fatwas of the Dar al-Ifta, Leiden: Brill.

Soroush, A. (2000) Reason, freedom, and democracy in Islam. Essential writings of Abdolkarim Soroush, Oxford: Oxford University Press.

Sourdel, D. (1990) 'Khalīfa: The history of the institution of the Caliphate', Encyclopaedia of Islam, Leiden: Brill.

Sulaiman, S.J. (1998) 'Democracy and shura', in C. Kurzman (ed.) Liberal Islam. A sourcebook, Oxford: Oxford University Press.

Syzow (2002) 'Zakat', Encyclopaedia of Islam, Leiden: Brill.

Tamandonfar, M. (1989) The Islamic polity and political leadership. Fundamentalism, sectarianism and pragmatism, Boulder: Westview Press.

Tibi, B. (1990) Islam and the cultural accommodation of social change, Boulder: Westview Press.

Tyan, E. (1999) Institutions de droit public Musulman, Beirut: Hassib Dergham \& Fils.

Warde, I. (2001) 'Islamic finance', Le Monde Diplomatique (English version).

Weiss, B. (1978) 'Interpretation in Islamic law: The theory of ijtihad', The American Journal of Comparative Law, vol. 26.

Ye'or, B. (1985) The dhimmi: Jews and Christians under Islam, London and Toronto: Associated University Press.

Zafar, S.M. (1998) 'Accountability, parliament and ijtihad', in C. Kurzman (ed.) Liberal Islam. A sourcebook, Oxford: Oxford University Press.

Zweigert, K. and H. Kötz (1996) An introduction to comparative law (2nd ed.), Oxford: Oxford University Press. 


\section{VERKLARENDE WOORDENLIJST}

\author{
Adatrecht \\ Adl (mv. udul) \\ Ahmadiyya
}

Al-Dawla al-Isla-
miya
Ayatollah
Bahais

Baya

Da(k)wa

Dar al-Harb

Dar al-Islam

Darar

Dhimma

\section{Dhimmi}

Diyya

Emir(aat)

Faqih

(mv. fuqaha)

Fatwa

Fiqh

Gharar

Groot-Mufti

Hadd (mv. hudud)

Hajj

Hadana

Hakim

Haram

Hiraba

Hisba

Hudud
Ongeschreven gewoonterecht in de Indonesische archipel

Beroepsgetuige (m.n. in de Maghreb-landen)

Religieuze groepering in Pakistan die zichzelf islamitisch noemt maar als ketters wordt bestempeld door de orthodoxe moslims

'Islamitische staat'

Shiitische religieuze titel (Iran)

Aanhangers van de gelijknamige Perzische godsdienst (m.n. in Iran)

Bekrachtiging van de leider door het volk

Islamitische zending

Leefgebied der ongelovigen

Leefgebied van moslims; territoir waar sharia van toepassing is Leed of schade (als grond voor echtscheiding)

Beschermde status van de niet-moslimse gemeenschap in Dar al-Islam

Niet-moslim woonachtig in Dar al-Islam (deze status is vaak beperkt tot joden en christenen)

Compensatie (bloedgeld), te betalen als tegenwaarde voor verwonding of doodslag

Generaal (prinsdom)

Rechtsgeleerde, expert in fiqh

Uitspraak op basis van de sharia inzake individuele vragen; juridisch advies

1. De islamitische rechtswetenschap waarmee de goddelijke bedoeling met de maatschappij achterhaald kon worden, 2. Het corpus van regels dat door deze wetenschap is ontwikkeld

Onzekerheid, speculatie

Hoogste uitvaardiger van fatwas, door de overheid aangesteld

Misdrijven, vastgesteld in de Koran

Bedevaart naar Mekka

Verzorgingsplicht jegens de kinderen

Arbiter

Zondig, verboden

Struikroverij (hadd-misdrijf)

Controle op juist gedrag

Zie: Hadd 
Idda

Ijma

Ijtihad

Imam

Jamat-I-Islami

Jihad

Jinayat

Jizya

Kafa'a

Kafir

Kalief

Kanun

Khanaat

Khul

Madhhab

(mv. Madhhahib)

Mahdi

Mahr

Mazalim

Mu'abadat

Mu'amalat

Mudaraba

Muddawana

Mufti

Muhtasib

Mujtahid

Musharaka

Muta

Nafaqa

Niqab

Nushuz

Qadhf

Qadi

Qanun

Qisas
Wachtperiode van de vrouw nadat haar huwelijk door scheiding of overlijden is ontbonden

Consensus

Interpretatie, methode van rechtsvinding

1. Leider van de geloofsgemeenschap, 2. Voorganger in gebed Puriteinse moslimgroepering in Pakistan

1. Inspanning om goed moslim te zijn ('grote jihad'), 2. Gewapende strijd ter verdediging van de islam ('kleine jihad')

Vergeldingsrecht inzake moord, doodslag en mishandeling

Hoofdelijke belasting voor niet-moslims in Dar al-Islam

Gelijkheid in sociale status tussen bruidegom en bruid

Ongelovige

Opvolger van de Profeet, leider van de Umma

Regelgeving of wet die is afgekondigd door de overheid

Vorstendom in Centraal-Azië

Echtscheiding met wederzijdse instemming van de echtgenoten en tegen een compensatie te voldoen door de vrouw aan de man

Rechtsschool

Verlosser

Bruidsgave, te betalen door de bruidegom aan de bruid

Tribunaal waar de burger klachten over autoriteiten aan de vorst kon voor leggen

Handelingen tussen mens en god

Handelingen tussen mensen onderling; contractenrecht

Commanditaire vennootschap

Marokkaans wetboek van familierecht

Uitvaardiger van fatwas

Marktmeester; degene die belast is met de hisba

1. Degene die ijtihad praktiseert, 2. Schriftgeleerde (Iran)

Vennootschap

Tijdelijk huwelijk (shiitisch)

Onderhoudsplicht van de man jegens zijn vrouw en kinderen

Gezichtbedekkende sluier

Ongehoorzaamheid van de vrouw jegens haar echtgenoot

Ongegronde beschuldiging van seksueel verkeer buiten het huwelijk (hadd-misdrijf)

Rechter

Zie: Kanun

Vergelding bij lichamelijk letsel (ius talio, ofwel 'oog om oog, tand om tand') 


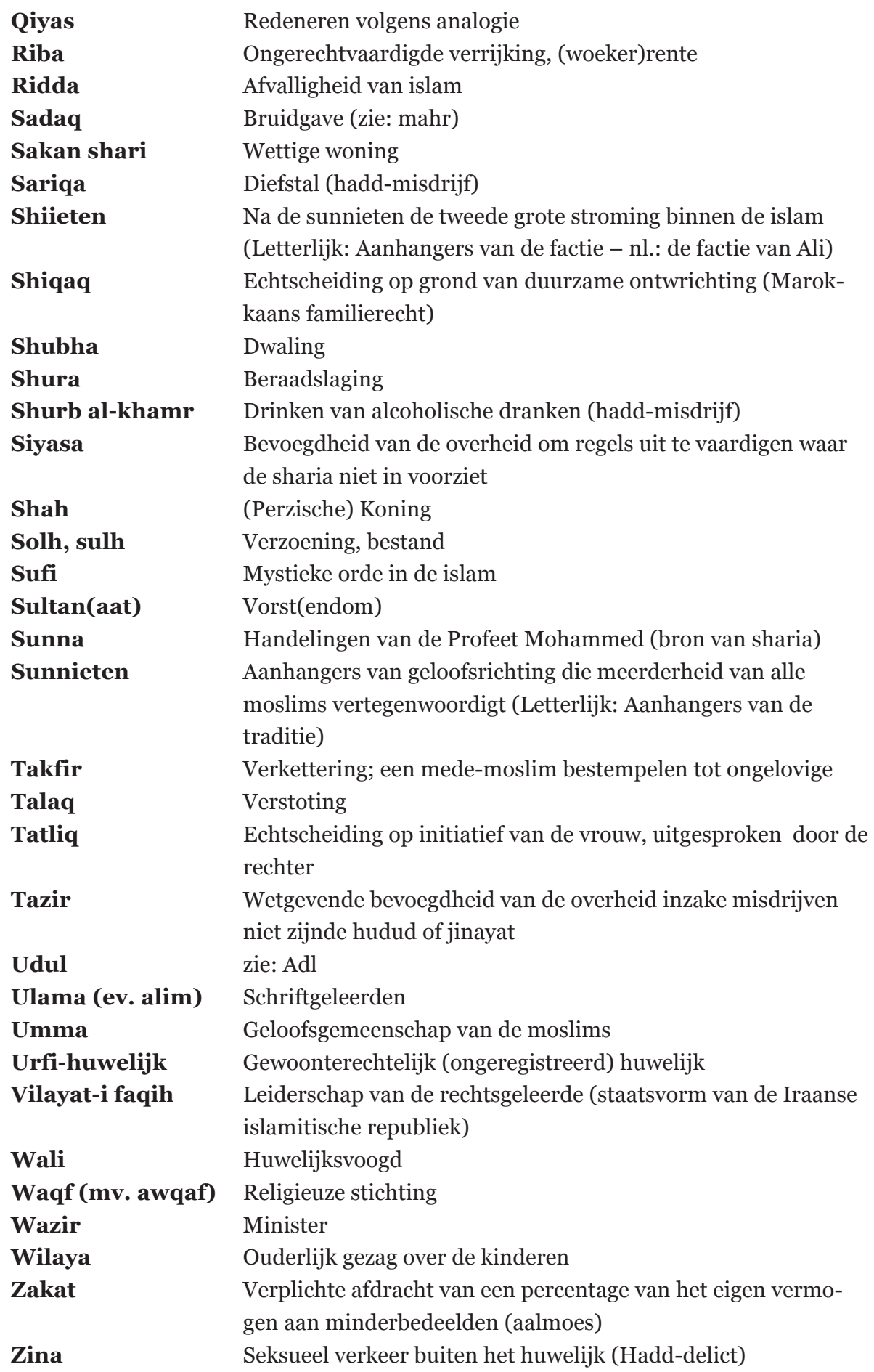

